\title{
2. NEOGENE TECTONIC EVOLUTION OF THE NEW HEBRIDES ISLAND ARC: A REVIEW INCORPORATING ODP DRILLING RESULTS ${ }^{\mid}$
}

\author{
H. Gary Greene, ${ }^{2,3}$ Jean-Yves Collot ${ }^{4}$ Michael A. Fisher, ${ }^{2}$ and Anthony J. Crawford ${ }^{5}$
}

\begin{abstract}
Evolution of the New Hebrides Island Arc occurred primarily during the Neogene, when, as part of the Vitiaz Arc it was ripped away from Fiji and Tonga and rotated clockwise (westward) to its present position. A combination of subduction polarity reversal, backarc spreading, and ridge-arc collision is responsible for the present-day configuration of the arc. During Ocean Drilling Program (ODP) Leg 134 drilling in the central New Hebrides Island Arc, where the collision of the d'Entrecasteaux Zone occurs, new information was revealed that resolves questions of timing for d'Entrecasteaux Zone collision, the style of arc deformation associated with colliding ridges, and rates of North Fiji Basin opening. These results constrain late Cenozoic relative plate motion along this section of the Australian (Australia-India) and Pacific Plate boundary.

The opening of the North Fiji Basin, the separation of the New Hebrides Island Arc from the Vitiaz Trench, and the counter-clockwise rotation of the arc probably started sometime between 10 and $12 \mathrm{Ma}$. A mean relative convergence rate of 13.8 to $14.8 \mathrm{~cm} / \mathrm{yr}$ between the Australian (Australia-India) and Pacific plates, was determined based on the chronostratigraphy of Bougainville Guyot (Site 831). Initial impact of the d'Entrecasteaux Zone may have occurred at $\sim 1.5-3.0 \mathrm{Ma}$ in the vicinity of Epi Island and has propagated northward along the forearc at a rate of 2 to $4 \mathrm{~cm} / \mathrm{yr}$.

Offscraping of material from the North d'Entrecasteaux Ridge is documented by nine major and four minor thrust sheets, located in the d'Entrecasteaux Zone-arc collision area (Sites 827 and 829) on the forearc slope of the central New Hebrides Island Arc, which lithologically and chronologically correlate with sedimentary and volcanic rocks drilled on the North d'Entrecasteaux Ridge (Site 828). The accretion of the ridge material is actively building Wousi Bank, a shallow, rising ridge located offshore of west-central Espiritu Santo Island.

Holes drilled in the North Aoba Basin (Sites 831 and 832) indicate that basin depths have varied between abyssal and shallow bathyal depths. One, or possibly two, unconformities drilled along the flanks of the North Aoba Basin suggests two phases of flank inclination along the basin resulting in mass wasting along the flanks. One unconformity, penetrated at a depth of $\sim 700 \mathrm{mbsf}$ in Hole 832B, has a 0.13-0.44 m.y. hiatus. This unconformity appears to represent the time that the d'Entrecasteaux Zone collided with the arc from central to southern Espiritu Santo Island, causing major uplift of the island during early Pleistocene time.

The d'Entrecasteaux Zone collision has had a major impact on arc magmatism. Regular volcano spacing ( $80-90 \mathrm{~km})$ occurs for the southern New Hebrides Island Arc volcanoes as far north as Epi. From Epi northwards to Santa Maria this spacing is severely disrupted in the collision zone. Several huge low-profile, Hawaiian-type basaltic shield volcanoes (Ambrym, Aoba) occur along major cross-arc fractures induced by the collision. These volcanoes contain abnormal amounts of primitive picritic and ankaramitic lavas, suggesting relative ease of access for these magmas from their mantle sources to eruption. Furthermore, post-d'Entrecasteaux Zone collision basaltic and andesitic magmas have a similar range of major and trace element compositions as pre-collision magmas, but profoundly different isotopic compositions than the pre-collision lavas. For example, the sill complex from the base of Hole $833 \mathrm{~B}$ and dated at 3.3 to $3.6 \mathrm{Ma}$ has ${ }^{206} \mathrm{~Pb} /{ }^{204} \mathrm{~Pb}$ and ${ }^{87} \mathrm{Sr} /{ }^{86} \mathrm{Sr}$ values of 18.7 to 18.8 and $0.7025-7030$, respectively, similar to values for volcanoes in the New Hebrides Island Arc remote from the collision zone. In contrast, post-d'Entrecasteaux Zone collision lavas from the Central Belt islands of Santa Maria, Aoba, and Ambrym, and lavas drilled in Hole 832B lithostratigraphic Units I, II, III, and IV have ${ }^{206} \mathrm{~Pb} / 204 \mathrm{~Pb}$ values of 18.1 to 18.3 and ${ }^{87} \mathrm{Sr} /{ }^{86} \mathrm{Sr}$ values around 0.7040 . The origin of the "enriched" component that isotopically distinguishes the post-collisional magmas has not been identified, but it is unlikely to be directly derived from the d'Entrecasteaux Zone, as drilled d'Entrecasteaux Zone lavas are isotopically matched to the pre-collision and southern arc lavas.

Collision and subduction of the d'Entrecasteaux Zone is currently indenting the forearc (Site 830) and causing uplift of the islands of the Western and Eastern belts of islands. Offscraping of the North d'Entrecasteaux Ridge sedimentary and volcanic rocks is active and northward migration of the d'Entrecasteaux Zone continues to deform new parts of the central New Hebrides Island Arc forearc slope. Erosion of these islands and Pleistocene effusive volcanic products of the Central Chain volcanoes contribute sedimentary fill to the North Aoba Basin at a rate of $286 \mathrm{~m} / \mathrm{m} . \mathrm{y}$. Soon $(\sim 0.5 \mathrm{~m} . \mathrm{y}$. ) the West Torres Massif and the Loyalty islands will collide with the north-central and southern part of the arc, and new episodes of island elevation, basin formation, and arc fragmentation will occur.
\end{abstract}

\section{INTRODUCTION}

The New Hebrides Island Arc is located in the southwest Pacific Ocean (Fig. 1). The arc includes islands of the eastern province of the Solomon Islands (the Santa Cruz Group) and the Republic of Vanuatu (formerly known as the New Hebrides Condominium; Fig. 2). The

'Greene, H.G., Collot, J.-Y., Stokking, L.B., et al., 1994. Proc. ODP, Sci. Results, 134: College Station, TX (Ocean Drilling Program).

${ }^{2}$ U.S. Geological Survey, Menlo Park, CA 94025 , U.S.A.

${ }^{3}$ Moss Landing Marine Laboratories, Moss Landing, CA 95039, U.S.A.

${ }_{4}^{4}$ ORSTOM, Villefranche-sur-Mer, France.

${ }^{5}$ Geology Department. University of Tasmania, Hobart. Tasmania 7001. Australia. arc is the product of active Cenozoic collision and subduction of the Pacific and Australian (Australia-India) plates. The central part of the arc consists of two major island belts (the Western and Eastern belts) separated by intra-arc basins and the active Volcanic Central Chain of submarine volcanoes and volcanic islands (Fig. 3).

The d'Entrecasteaux Zone (DEZ), composed of the North d'Entrecasteaux Ridge (NDR) and the South d'Entrecasteaux Chain (SDC) of seamounts and guyots, is an arcuate feature that extends to the west and south from the arc to merge with the New Caledonia Ridge (Fig. 2). Luyendyk et al. (1974) suggested that the DEZ was a fracture zone. Daniel et al. (1977) and Malliet et al. (1983) suggested that the DEZ is the northern arcuate extension of a northeast-dipping Eocene subduction/obduction system, parts of which are exposed on New Caledonia. 


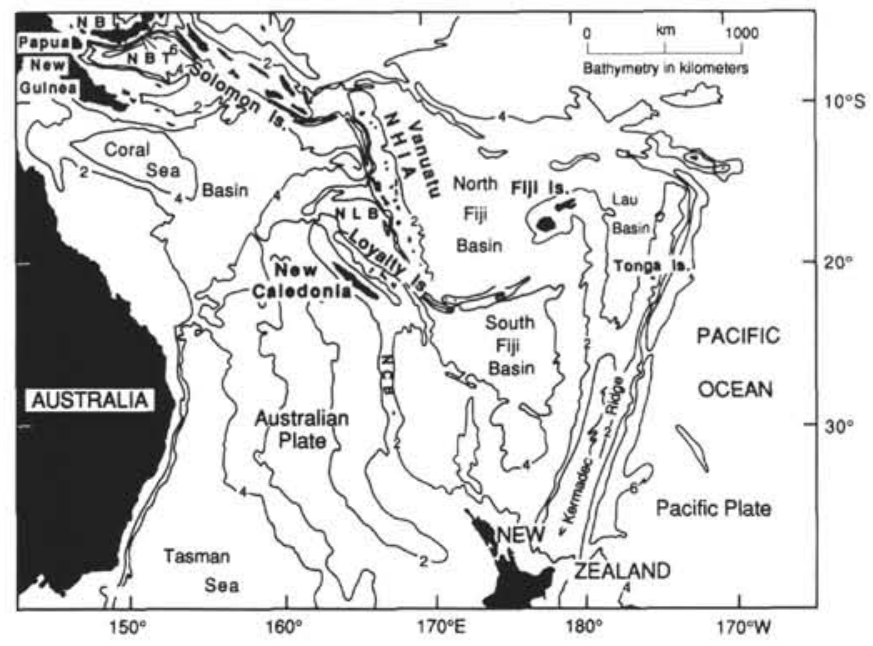

Figure 1. Map showing location of island arcs and major basins in the southwest Pacific. NHIA is New Hebrides Island Arc; NLB is North Loyalty Basin; NB is New Guinea Basin; NBT is New Britain Trench; NCB is New Caledonia Basin.
North of the DEZ, the West Torres Massif is in the initial stages of collision with the forearc slope of the north central New Hebrides Island Arc (Fig. 2), and initial deformation of the North New Hebrides Trench is observed on the seafloor (Burne et al., 1988). South of the DEZ lies the North Loyalty Basin, an oceanic basin that separates the Loyalty Ridge from the South New Hebrides Trench. The Australian (Australia-India) Plate in the North Loyalty Basin, south of the DEZ, is early Eocene in age (Weissel et al., 1982). The southern part of the Loyalty Ridge is about to collide with the southern New Hebrides Island Arc (Dubois et al., 1974; Monzier, et al., 1983). The Deep Sea Drilling Project (DSDP) drilled in the northeastern part of the Loyalty Basin at DSDP Site 286 (Shipboard Scientific Party, 1975).

The central New Hebrides Island Arc exhibits unique physiography (Greene, Macfarlane, and Wong, 1988) in that the summit platform area is composed of two distinct bedrock ridges and islands (the Western and Eastern belts of islands) separated by the Aoba Basins and the active volcanoes of the Central Chain. Here the DEZ is in contact with the forearc slope obliterating the physiographic expression of the trench (Fig. 3).

Major lineaments that transect and segment the New Hebrides Island Arc are evident from bathymetric, gravity, and seismic reflection data (Fig. 4; Malahoff, 1970; Karig and Mammerickx, 1972; Daniel, 1978; Monzier et al., 1983; Collot and Fisher, 1988; Greene,

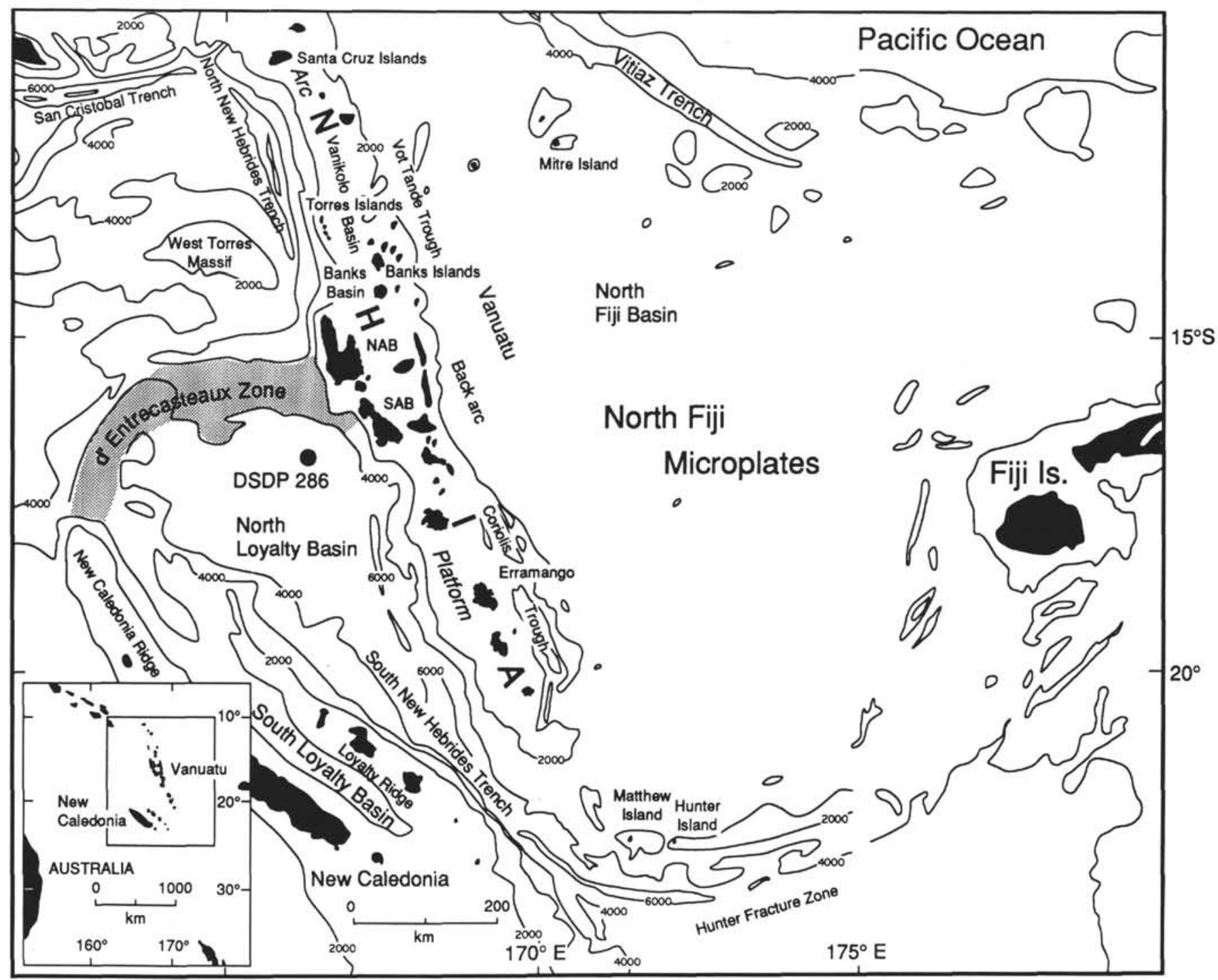

Figure 2. Regional bathymetry (in meters) and island distribution in the southwest Pacific. NCR is New Caledonia Ridge. NAB is North Aoba Basin; SAB is South Aoba Basin; DSDP is Deep Sea Drilling Project (modified after Kroenke et al., 1983). 
Macfarlane, and Wong, 1988; Greene, Macfarlane, Johnson, and Crawford, 1988). In the central part of the arc, lineaments ranging in trends from northwest to northeast between Ambrym and Aoba islands (Fig. 4) result from the collision of the DEZ with the arc (Collot et al., 1985; Katz, 1988; Greene, Macfarlane, Johnson, and Crawford, 1988). The structure of the central part of the arc is dominated by arcparallel, arc-oblique, and arc-transverse faults and fracture zones (Macfarlane et al., 1988; Greene, Macfarlane, Johnson, and Crawford, 1988; Fig. 4). Arc-parallel faults may have resulted from thermal arching during subduction (Carney and Macfarlane, 1977, 1982; Greene, Macfarlane, Johnson, and Crawford, 1988), whereas arcoblique and arc-transverse faults appear to have resulted from collisional processes (Greene, Macfarlane, Johnson, and Crawford, 1988). Arc-parallel and arc-oblique faults bound horst blocks that form most islands and grabens in which deep- and shallow-water sedimentary basins formed. Arc-transverse faults offset these structural features and act as magma conduits from which some of the islands of the Central Chain may have formed (Crawford et al., 1988; Greene, Macfarlane, Johnson, and Crawford, 1988).

\section{Drilling Objectives}

The objectives of Ocean Drilling Program (ODP) Leg 134 in the central part of the New Hebrides Island Arc were focused on three important and poorly understood tectonic processes that occur along aseismic ridge-island arc collision zones and include (1) determining the differences in the style of deformation associated with two different types of ridges (a fairly continuous, smooth topographic ridge and a more serrated, irregular topographic seamount chain) that are colliding with the central New Hebrides Island Arc, (2) documenting the evolution of the magmatic arc in relation to the collision process, and possible Neogene reversal of subduction, and (3) understanding the process of dewatering of a small accretionary wedge associated with ridge collision and subduction. This paper reviews, and where necessary revises, the tectonic history of the region. Our intent is to set the stage for the other chapters in this volume and to apply ODP drilling results to the interpretation of southwest Pacific regional geologic and tectonic evolution.

\section{Previous Work}

Greene, Macfarlane, and Wong (1988) summarize the geological and geophysical work undertaken in the central New Hebrides Island Arc and Macfarlane et al. (1988) summarize the island and tectonic studies of the region. We refer the reader to these references for further information on pre-1988 work.

In preparation for Leg 134 drilling, site surveys were conducted in the central New Hebrides Island Arc during SEAPSO and MULTIPSO investigations by the Institut Français de Recherche pour l'Exploration de la Mer (IFREMER) and Office de la Recherché Scientifique et Technique Outre-Mer(ORSTOM) (Daniel et al., 1989; Collot and Fisher, 1988, 1991; Fisher et al., 1991). Additional data were collected in the region by ORSTOM during the EXA XIII studies, and submersible observations were made and geological sampling undertaken in 1987 on the forearc slope in the d'Entrecasteaux collision zone, during the ORSTOM-IFREMER SUBPSO investigations (Collot et al., 1989, 1992; Greene et al., 1992). Further updated work is referred to in Collot, Greene, Stokking, et al. (1992).

\section{TECTONIC SETTING}

The New Hebrides Island Arc lies in the center of a complex, sinuous chain of active island arcs, including Papua New Guinea-New Britain, Solomon Islands, New Hebrides (Vanuatu), Fiji, Tonga, and Kermadec. This island arc system marks the present-day boundary between the Australian (Australia-India) and Pacific plates. In the north, the Australian Plate is subducting eastward beneath the Pacific

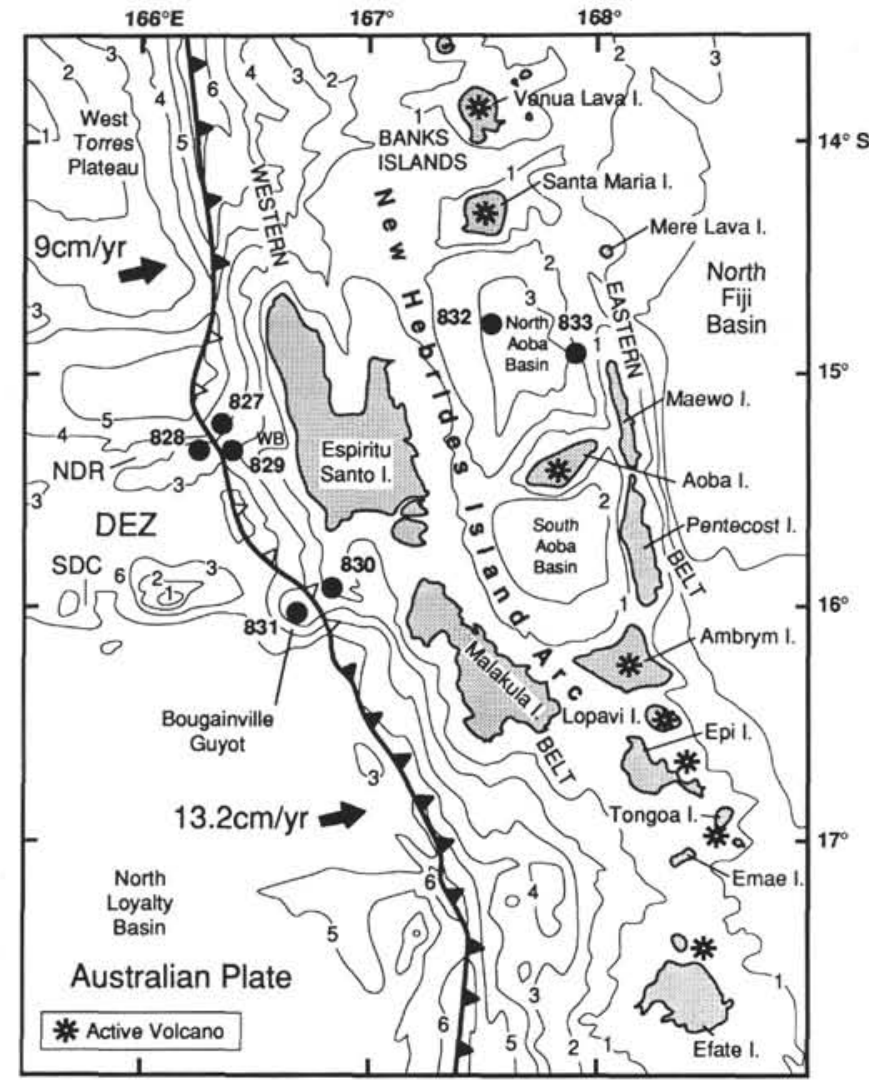

Figure 3. Map showing physiographic features and Leg 134 drilling sites (large dots) in the central New Hebrides Island Arc area. Large asterisk indicate active volcanoes. Barbed heavy line shows trace of subduction zone; barbs on upper plate, open barbs where trench is clogged. Bathymetry in kilometers. NDR is North d'Entrecasteaux Ridge, DEZ is d'Entrecasteaux Zone, SDC is South d'Entrecasteaux Chain, I. is Island, WB is Wousi Bank.

Plate (New Britain, San Cristobal, and New Hebrides trenches and the microplates of the North Fiji Basin) and in the south the Pacific Plate is subducting westward beneath the Australian (Australia-India) Plate (Tonga-Kermadec trenches, South Fiji Basin, and the microplates of the Lau Basin) (Figs. 1 and 2). The New Hebrides Island Arc extends from the Santa Cruz Group of islands, Solomon Islands, in the north, to Matthew and Hunter islands in the south (Fig. 2), a distance of $1700 \mathrm{~km}$.

\section{General Arc Geomorphology}

Greene, Macfarlane, and Wong (1988) described the New Hebrides Island Arc as consisting of three major physiographical or morphological provinces: trench, arc platform complex with active volcanic chain, and backarc (Fig. 2). These components are summarized below.

\section{Trench}

The trench is a well defined sinuous feature that is composed of northern (North New Hebrides Trench) and southern (South New Hebrides Trench) parts. The entire trench averages $6000 \mathrm{~m}$ in depth, but locally reaches $7000 \mathrm{~m}$. The trench is the seafloor expression of an east-dipping Benioff zone (Karig and Mammerickx, 1972; Pascal et al., 1978; Louat et al., 1988; Macfarlane et al., 1988). The divide between the North and South New Hebrides trenches is offshore of central Espiritu Santo and northern Malakula islands, where the DEZ of two parallel ridges clogs the trench (Fig. 3; Daniel, 1978; Collot et al., 1985; Fisher et al., 1986). Irregular seafloor topography in this area, in and adjacent to the trench, on the Australian (Australia-India) Plate, 


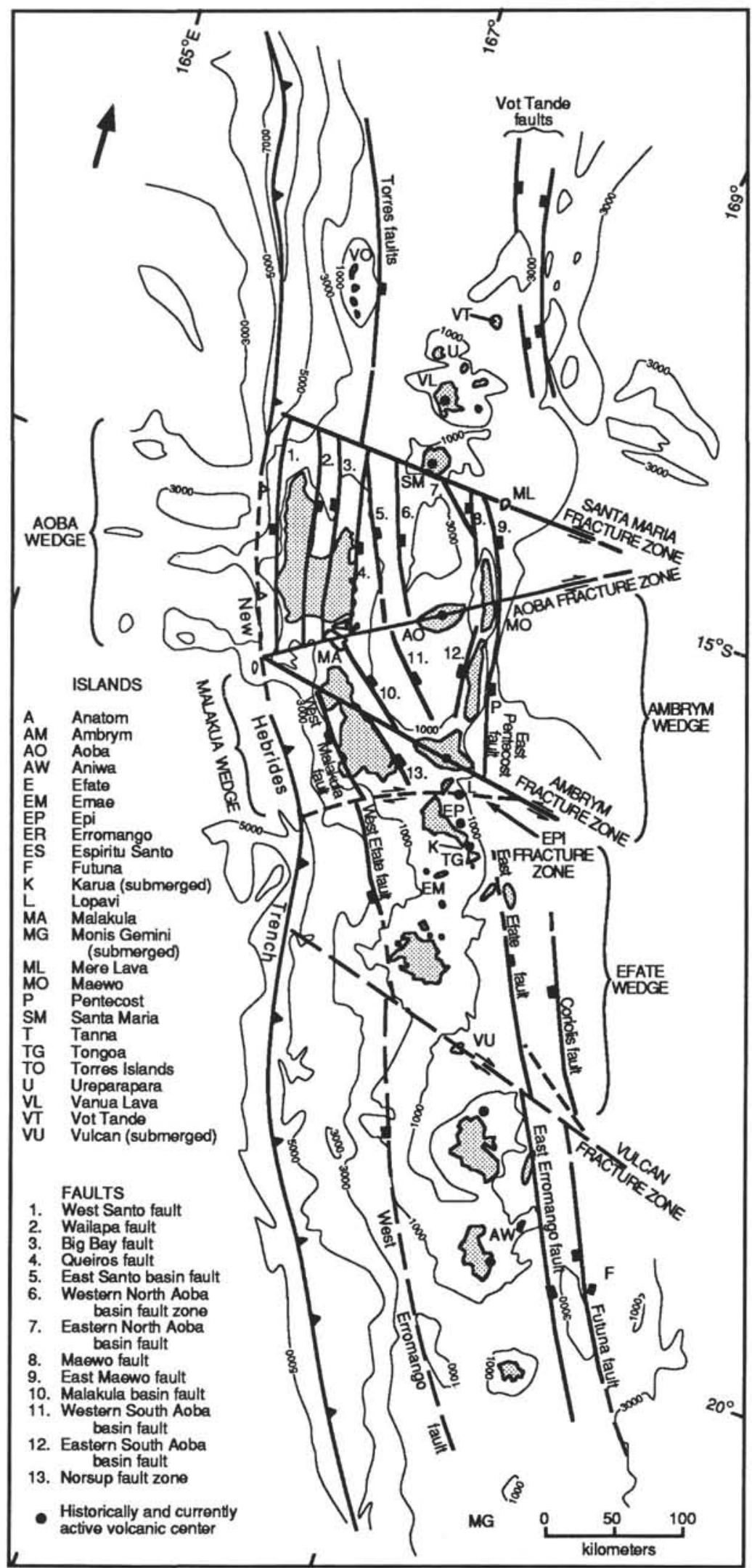

Figure 4. Major structural lineaments (faults and fracture zones) and islands of the central New Hebrides Island Arc (Vanuatu). Lines dashed where inferred, volcanic centers (small dots); barbed line same as in Figure 3. Structural blocks or "wedges" are indicated (modified after Greene, Macfarlane, Johnson, and Crawford, 1988). 
ranges from 3000 to $5000 \mathrm{~m}$ and is marked by isolated deeper depressions and shallower highs (Daniel and Katz, 1981; Collot et al., 1985).

The geomorphology of the forearc slope of the New Hebrides Island Arc varies from a relatively smooth, narrow ( 40-km-wide) feature adjacent to the North New Hebrides Trench, to an irregular, less steep, wide $(\sim 80 \mathrm{~km})$ feature pock-marked by circular indentations inboard of the South New Hebrides Trench. In the central part of the New Hebrides Island Arc, where the trench is clogged by the DEZ, the forearc slope is quite narrow (only about 20-km-wide) and exhibits a distinct westward offset by approximately $35 \mathrm{~km}$. This offset is best illustrated by Wousi Bank and the uplifted western part of Espiritu Santo Island, which is essentially an emergent forearc slope (Fig. 3).

Accretionary prisms are either nonexistence or poorly developed on the forearc slopes adjacent to the North and South New Hebrides Island trenches. However, a small $(\sim 60 \times 35 \mathrm{~km})$ accretionary wedge exists where the North d'Entrecasteaux Ridge is colliding with the Central New Hebrides Island Arc.

\section{Arc Platform}

The arc platform has a complicated and irregular topography consisting of basins and ridges, which includes the active volcanic chain (the Central Chain) - a sinuous, generally north-northwesttrending series of active and recently inactive volcanic islands. The width and form of the arc platform vary considerably along the arc. The location of the central chain also varies considerably along the arc; for example, the active volcanic chain lies generally $150 \mathrm{~km}$ east of the trench in the north and south, but it lies $\sim 100 \mathrm{~km}$ east of the trace of the trench in the central part of the arc. Within the platform of the central New Hebrides Island Arc and bounded on the east by the backarc zone is an intra-arc sedimentary basin (median sedimentary basin of Ravenne et al., 1977; Carney and Macfarlane, 1980). This basin is divided into two separate and distinct physiographic basins, the North Aoba Basin and South Aoba Basin of Katz (1981), with water depths of 2000-3000 m (Fig. 3). Between these basins, here referred to in combination as the Central (Aoba) Basins, and Espiritu Santo and Malakula islands are small subshelf basins located in water depths of about $1000 \mathrm{~m}$ (Greene and Johnson, 1988). North of the Central Basins, the intra-arc basin is subdivided into the Banks Basin and the Torres-Santa Cruz Basin of Katz (1981), or Vanikolo Basin (Fig. 2) of Greene, Macfarlane, and Wong (1988). South of Ambrym, no intra-arc basin exists. However, between the islands of Erromango and Efate, a restricted sedimentary basin may be present.

\section{Backarc}

The backarc, which is characterized by irregular seafloor at a water depth of $2000-3000 \mathrm{~m}$, is continuous with the North Fiji Basin (Fig. 2). In the central part of the New Hebrides Island Arc no backarc-like troughs exist that are similar to those present to the north and south (Karig and Mammerickx, 1972; Dubois et al., 1975, 1978; Recy et al., 1986, 1990; Charvis and Pelletier, 1989). Even so, the seafloor is highly irregular and broken along the eastern flanks of Maewo and Pentecost islands, and the bathymetry in this area appears to be controlled by lava flows and a westward-dipping thrust fault that breaks the seafloor (Tiffin et al., 1990; Price et al., 1993). The entire backarc region is the North Fiji Basin, composed of three distinct microplates with a ridgeridge-transform (North Fiji Fracture Zone) triple-junction located in the southeastern part of the basin (Auzende et al., 1988).

\section{Island Geology}

The central New Hebrides Island Arc has been divided into three distinct island arc volcano-tectonic provinces, which are, from oldest to youngest, the Western Belt, the Eastern Belt, and the Central Chain. These provinces apparently formed during three temporally and spa- tially overlapping volcanic episodes that occurred since the late Oligocene. The Western Belt is composed of upper Oligocene to middle Miocene volcanic rocks of Malakula, Espiritu Santo, and the Torres Group of islands. The Eastern Belt consists of the upper Miocene to lower Pliocene volcanic rocks of Pentecost and Maewo islands. The Central Chain comprises the Pleistocene, and perhaps older, volcanic islands of Ambrym, Aoba, Mere Lava, and Santa Maria (Figs. 2 and 3 ). Below we briefly describe the island geology; for more detail see Macfarlane et al. (1988).

\section{Western Belt}

The Western Belt of islands is on the western margin of the arc summit platform (Mitchell, 1966, 1971; Greenbaum et al., 1975; Mallick and Greenbaum, 1977; Hughes, 1978; Carney and Macfarlane, 1982; Macfarlane et al., 1988). Basement rocks in the Western Belt are of submarine upper Oligocene to middle Miocene calc-alkaline lavas and associated volcaniclastic rocks intruded by late-stage gabbro, andesite, and micro-diorite stocks (Fig. 5). The lower part of this volcanic sequence is exposed only on Malakula Island, where it consists of abyssal red mudstone of proposed Oligocene age, in highangle fault contact with the volcanic rocks (Mitchell, 1971; Macfarlane et al., 1988).

Basinal graywacke of middle Miocene age lies east of, and in fault contact with, Oligocene to Miocene volcanic rocks that form the main volcanic axis on Espiritu Santo Island. The top of this hemipelagic carbonate sequence grades upward into Pliocene shallow-marine sedimentary rocks that bear terrigenous material (Tawoli Formation of Espiritu Santo; Macfarlane et al., 1988). Quaternary reef limestone is extensively deposited over the older successions, but does not entirely cover the islands. At the end of the middle Miocene, uplift and erosion was followed by subsidence and marine transgression across the Western Belt islands. On Espiritu Santo Island, the transgression is marked by a middle Miocene unconformity separating middle Miocene volcaniclastic sandstone and graywackes from overlying late Miocene to Pliocene hemipelagic sedimentary rocks. On Malakula Island, Pliocene shallow-water sandstones and mudstones were deposited with high angular unconformity upon middle Miocene graywacke (Port Sandwich Formation). The unconformity marks the Pliocene transgression and is characterized by a thick (locally up to 5-m-thick) well rounded to poorly sorted boulder conglomerate (Macfarlane et al, 1988).

\section{Eastern Belt}

The Eastern Belt of islands consists of Maewo and Pentecost (Mallick and Neef, 1974; Macfarlane et al., 1988), which lie atop an uplifted horst or compressional ridge at the eastern margin of the arc summit platform (Figs. 2 and 3). The oldest strata are lower to middle Miocene volcaniclastic rocks and conglomerate (Sighotara Group and Tafwutmuto Formations on Maewo), which on Maewo contain terrigenous lava clasts with island-arc tholeiitic affinities (Carney and Macfarlane, 1978). Upper Miocene pelagic sedimentary rocks (Maewo Group) conformably overlie older Miocene volcaniclastic deposits on Maewo, but are absent from Pentecost Island. Submarine volcanism in the vicinity of the Eastern Belt ceased at $\sim 3 \mathrm{Ma}$, at about the same time ( $3.5 \mathrm{Ma})$ that ophiolites were emplaced in Pentecost (Macfarlane et al., 1988).

The Miocene and Pliocene island-arc, submarine volcanic rocks that have a transitional calc-alkaline/tholeiitic geochemistry are succeeded by Pliocene, pelagic, sedimentary rocks (Globigerina ooze of the Marino Formation on Maewo). These rocks are unconformably overlain by Pliocene and Pleistocene detrital limestone (Nasawa Formation on Maewo) and, finally, by Quaternary raised reef limestone. On Pentecost, the Miocene and Pliocene volcanic rocks are in highangle-fault contact with the basement complex, an ophiolite emplaced during the Pliocene that is composed of serpentinized peridotite and basic mid-ocean ridge basalt (MORB)-type metalava with amphibo- 
$167^{\circ}$

$168^{\circ}$

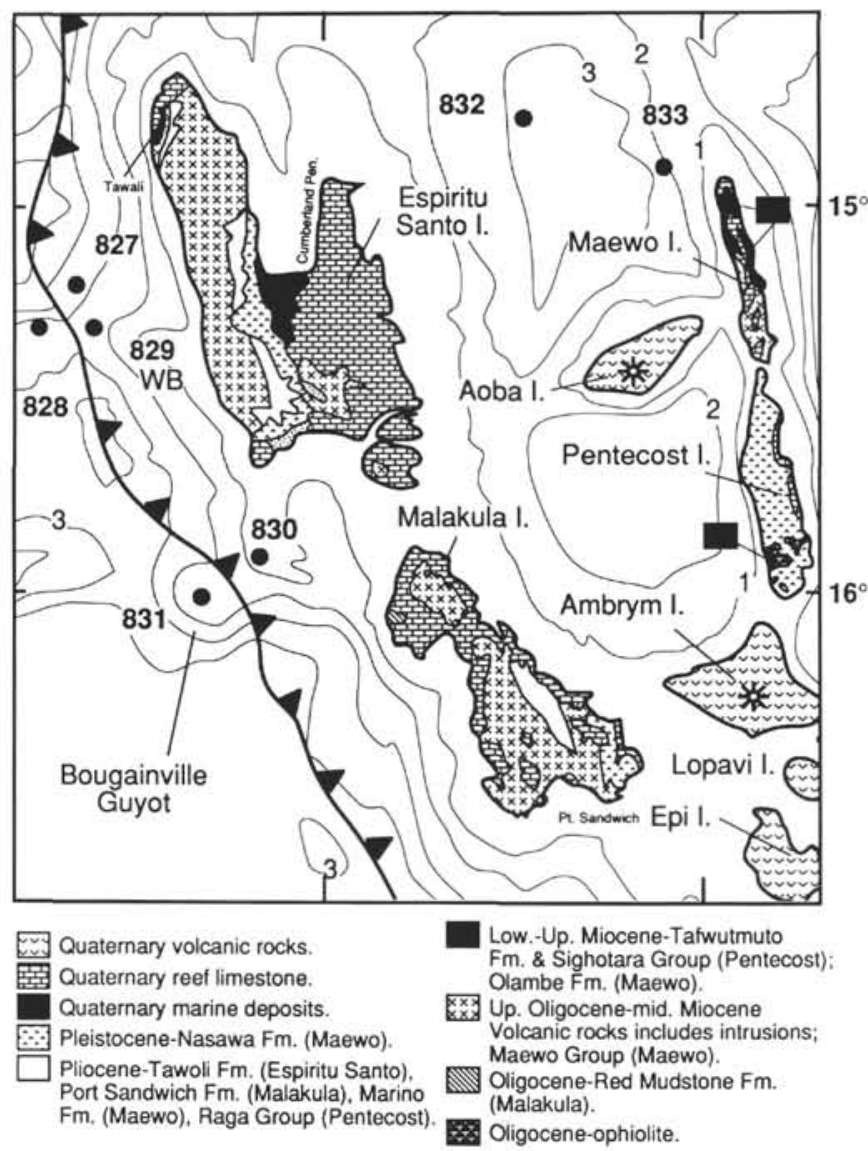

Figure 5. Geologic sketch map showing island geology of the central New Hebrides Island Arc. Large dots show location of drill sties (modified after Greene, Johnson, Macfarlane, and Wong (1988). Pen. is peninsula, I. is island, $\mathrm{Pt}$. is port, Up. is upper, $\mathrm{Fm}$. is formation.

lite and gabbro intrusions (Macfarlane et al., 1988). A gravity high over eastern Maewo, similar to the one over Pentecost (Malahoff, 1970), suggests that structurally shallow ultramafic intrusions may also occur on Maewo (Macfarlane et al., 1988). However, gravity modeling of the Eastern Belt do not require high density rocks (Peridotite) to account for the gravity high (Collot and Fisher, 1988). The origin of the ophiolite is problematic due to poor age control. Some researchers consider it to be part of an Oligocene spreading ocean ridge that formed prior to the formation of the Western Belt (Mallick and Neef, 1974; Carney et al., 1985), but the ophiolite might also include lavas and intrusions akin to tholeiitic arc magmatism (Macfarlane et al., 1988) and may represent the earliest manifestations of North Fiji Basin spreading.

\section{Central Chain}

The Central Chain is the presently active volcanic arc that is as old as $5.8 \mathrm{Ma}$ in the southern part of the arc, but is no older than Pleistocene in the central part (Colley and Ash, 1971; Bellon et al., 1984; Figs. 3 and 4). Rocks of this chain consist primarily of basalt and andesite with some dacite and picrite. These rocks vary from low-K tholeiite to high- $\mathrm{K}$ calc-alkaline and transitional alkaline rocks (Carney et al., 1985). Ankaramitic and picritic lavas are common on Ambrym and Aoba islands (Gorton, 1974; Briqueu and Lancelot, 1982). Carney and Macfarlane (1982) and Macfarlane et al. (1988) conclude from age dating that initial volcanism of the Central Chain was contemporaneous, at least in part, with volcanism of the Eastern Belt. This is substantiated with drilling at Site 833 .

\section{PROPOSED ORIGIN AND EVOLUTION OF THE ARC}

Many different models have been proposed to describe the origin of the New Hebrides Island Arc (e.g., Chase, 1971; Dickinson, 1973; Pascal et al., 1978; Falvey, 1975, 1978; Coleman and Packham, 1976; Ravenne et al., 1977; Carney and Macfarlane, 1977, 1978, 1979, 1980, 1982; Carney et al., 1985; Katz, 1988; Macfarlane et al., 1988). One proposal includes a reversal in subduction polarity sometime between 10 and $6 \mathrm{Ma}$ (Chase, 1971; Auzende et al., 1988), another favors a continuous eastward subduction throughout the Neogene (Luyendyk et al., 1974; Louat et al., 1988).

According to the polarity-reversal hypothesis, late Eocene southward subduction of the Pacific Plate beneath the Australian (AustraliaIndia) Plate at the Vitiaz Trench formed the Western Belt of the New Hebrides Island Arc behind (west of) the upper Eocene Vitiaz frontal arc (Fig. 6A). The tholeiitic New Hebrides Island Arc was continuous with the arcs of Tonga and the Solomon Islands (Outer Melanesian arc; Fig. 6A), which were located above the southwest-dipping subduction zone (e.g., Chase, 1971; Karig and Mammerickx, 1972; Gill and Gorton, 1973; Carney and Macfarlane, 1978; Falvey, 1978; Kroenke, 1984; Falvey and Greene, 1988). A later relocation of the plate boundary to a position south of the Vitiaz Arc, and a reversal in subduction direction, were accompanied by spreading and opening of the North Fiji Basin (Fig. 6B). This relocation occurred possibly because of the collision of the Ontong Java Plateau (Kroenke, 1984). This event and subduction flip initiated southwestward migration of the New Hebrides backarc, with the New Hebrides Island Arc south of Erromango moving away (westward) from Fiji. Later ( $\sim 3.5 \mathrm{Ma})$ propagation of the spreading center into the northwestern corner of the North Fiji Basin brought about rotation and westward migration of the northern (North of Erromango) part of the arc (Musgrave and Firth, 1993). When the Australian (Australia- India) Plate began to subduct beneath the Pacific Plate, the Eastern Belt and Central Chain islands began to form (Chase, 1971; Carney and Macfarlane, 1978, 1980; Kroenke, 1984; Macfarlane et al., 1988).

The alternative hypothesis to the origin and evolution of the New Hebrides Island Arc explains the formation of the three island belts by subduction of an east-dipping slab that changed inclination through time (Luyendyk et al., 1974; Carney and Macfarlane, 1977; Hanus and Vanek, 1983; Katz, 1988; Louat et al., 1988). Hanus and Vanek (1983) and Louat et al. (1988) use modern seismicity data to distinguish two different east-dipping subducting slabs, one broken off from the other. Periodic cessation of subduction, with breaking off of the downgoing lithospheric slab and shifting from a fairly steeply dipping Benioff zone to a shallower one and back again, is proposed to explain the west-toeast and subsequent east-to-west migration of the volcanic axis through time within the Central Basins region of the arc.

\section{DOCUMENTED NEOGENE EVOLUTION OF THE ARC THROUGH ODP DRILLING}

\section{Opening of the North Fiji Basin and Collision of the DEZ}

Results of Leg 134 refine the rates of plate motion in the vicinity of the central New Hebrides Island Arc. Absolute motion at the Australian (Australia-India) Plate near the New Hebrides Island and Solomon Islands arcs was estimated at $7 \mathrm{~cm} / \mathrm{yr}$ along a northeastern vector, whereas motion of the Australian (India-Australia) Plate relative to the central New Hebrides Island Arc was estimated at $10 \mathrm{~cm} / \mathrm{yr}$ along an eastern vector (Minster and Jordan, 1978; American Association of Petroleum Geologists, 1985). The relative motion of the New Hebrides Island Arc and the Australian Plate is primarily the result of spreading within the North Fiji Basin and clockwise rotation of the New Hebrides Island Arc around a nearby pole westward at a previously estimated relative plate motion of $10 \mathrm{~cm} / \mathrm{yr}$. This motion caused the arc to break away from Fiji and the northern Tonga Arc with the southern part of the New Hebrides Island Arc slipping 


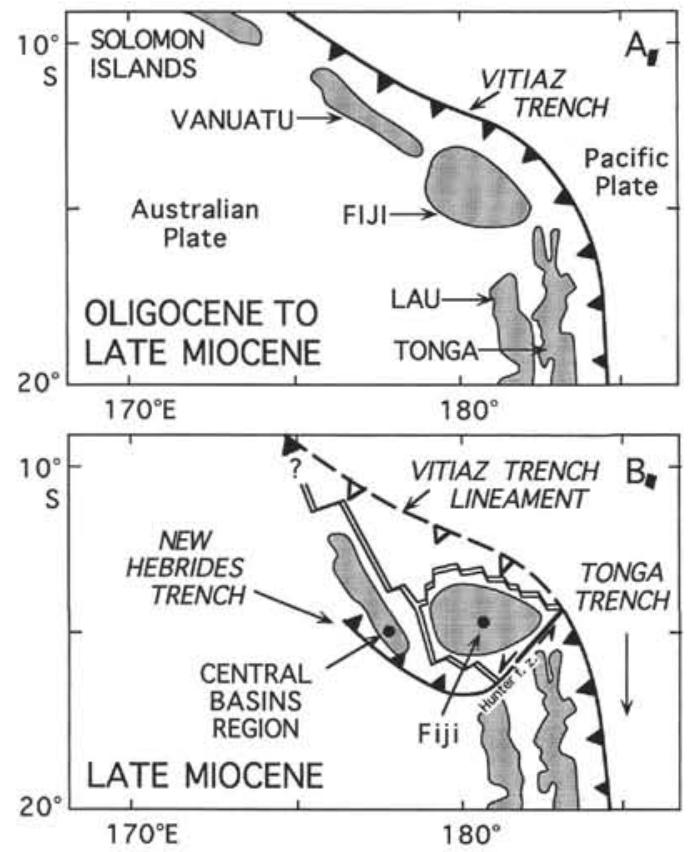

Figure 6. Tectonic evolution of the northern Melanesian borderland from (A) Oligocene through (B) late Miocene. Heavy barbed line shows trace of subduction zones; filled barbs indicate active zone, open barbs indicate inactive zone (modified after Brocher and Holmes, 1985; Falvey, 1978). f.z. is fracture zone.

left-laterally along the Hunter fracture zone (Fig. 6B; Minster and Jordan, 1978; American Association of Petroleum Geologists, 1985).

Quaternary rates are revised on the basis of Sr- and U-series radiometric dating of carbonate rocks within the Bougainville Guyot drilled at Site 831 (Quinn et al., this volume; Taylor et al., this volume). These authors indicate that considerably more rapid opening of the North Fiji Basin than previously proposed (Minster and Jordan, 1978; American Association Petroleum Geologists, 1985) has occurred and that the net relative rate of convergence (i.e., sum of New Hebrides Island Arc-Pacific Plate and New Hebrides Island Arc-Australian Plate motion) between the arc and the Australian Plate at the latitude of Espiritu Santo Island is approximately $14-16 \mathrm{~cm} / \mathrm{yr}$ since about 8-12 Ma.

\section{DEZ Collision Zone}

Drilling of the DEZ collision zone was undertaken to determine the style and degree of deformation occurring in the forearc slope of the New Hebrides Island Arc. Results of Leg 134 indicate that offscraping and accretion of sedimentary and volcanic rocks from the DEZ (North d'Entrecasteaux Ridge) is actively occurring and are exhibited as thrust sheets. The DEZ is a continuous system of ridges and topographic highs that is elevated 2 to $4 \mathrm{~km}$ above the seafloor, is over $100 \mathrm{~km}$ wide, and that extends for over $600 \mathrm{~km}$ from New Caledonia to Vanuatu, where it is in active collision with the central New Hebrides Island Arc (Fig. 2). Where the northern part of the DEZ, the North d'Entrecasteaux Ridge, is colliding with the arc, two drill sites ( 827 and 829 ) were occupied in order to determine the style of forearc deformation (Fig. 7). The different morphology and lithologies of the two colliding DEZ ridges (the North d'Entrecasteaux Ridge and the South d'Entrecasteaux Chain) result in differing evolution of the forearc.

\section{Site 827}

Drilling at Site 827 has shown that the $400 \mathrm{~m}$ of sediment and sedimentary rocks recovered here on the western flank of the Wousi

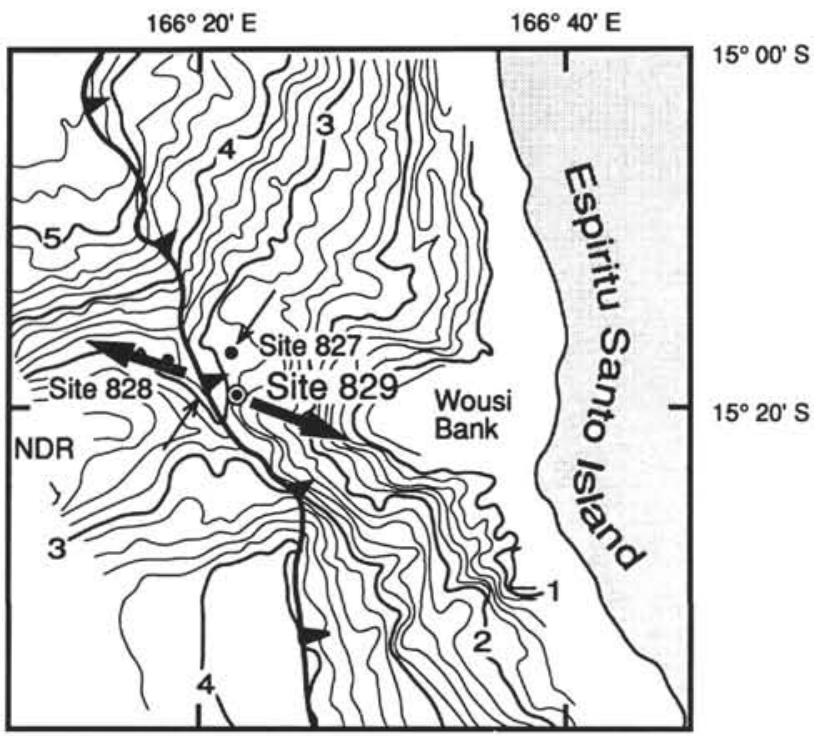

Figure 7. Map showing location of Leg 134 Sites 827,828 , and 829 where the North d'Entrecasteaux Ridge (NDR) is colliding with the New Hebrides Island Arc. Heavy barbed line shows seafloor trace of subduction zone. Heavy arrows show direction of borehole elongation based on BHTV data (Krammer et al., this volume), which lie perpendicular to the compressional stress orientation (light arrows) as determined from borehole breakout studies (Chabernaud, this volume).

Bank are primarily of volcanic derivation. These rocks were probably derived from the New Hebrides Island Arc, rather than from the subducting North d'Entrecasteaux Ridge, although the top of a Pleistocene thrust sheet that may be composed of materials from the North d'Entrecasteaux Ridge or the trench was penetrated.

The andesitic composition of clasts in the sed-lithic conglomerate of the lower part of Hole 827B, constituting lithostratigraphic Unit IV of late Pliocene and older age, suggests that they were derived from the present Western Belt of the arc, rather than from the North d'Entrecasteaux Ridge. A likely source for the arc-derived clasts and other volcanic sediment at Site 827 is nearby Espiritu Santo Island, which has abundant andesitic lavas and intrusions (Macfarlane et al., 1988) and has been exposed for at least 0.5 m.y. (Taylor et al., 1980, 1985,1987 ) and possibly since the middle Pliocene (Mallick and Greenbaum, 1977; Carney and Macfarlane, 1982). The only lithology encountered at Site 827 that does not show arc affinities is chalk clasts (some are early to middle Eocene in age) in the sed-lithic conglomerates of lithostratigraphic Unit III found in the middle segment of Hole 827B (Fig. 8). Eocene chalks are not known within the New Hebrides Island Arc. Thus these clasts could have been derived from chalk-like deposits on the subducting North d'Entrecasteaux Ridge, as suggested by the presence of upper Eocene chalk or firm ooze (Collot, Greene, Stokking, et al., 1992) on the ridge at Site 828. Also, the upper $150 \mathrm{~m}$ of the sequence recovered at Site 827 on the forearc slope is relatively undeformed, whereas the lower half is highly tectonized, further suggesting that it may represent accretion of material from the North d'Entrecasteaux Ridge. In addition, seismic reflection profiles across the forearc slope west of Wousi Bank show a series of thrust sheets at depth indicating accretion near the base of Hole 827B (Collot et al., this volume).

\section{Sites 828 and 829}

Lithostratigraphic and biostratigraphic data show that the sequence of rocks drilled at Site 829 represents an accretionary complex consisting of at least nine major and four minor imbricated thrust sheets (Meschede and Pelletier, this volume). Each thrust sheet consists of 


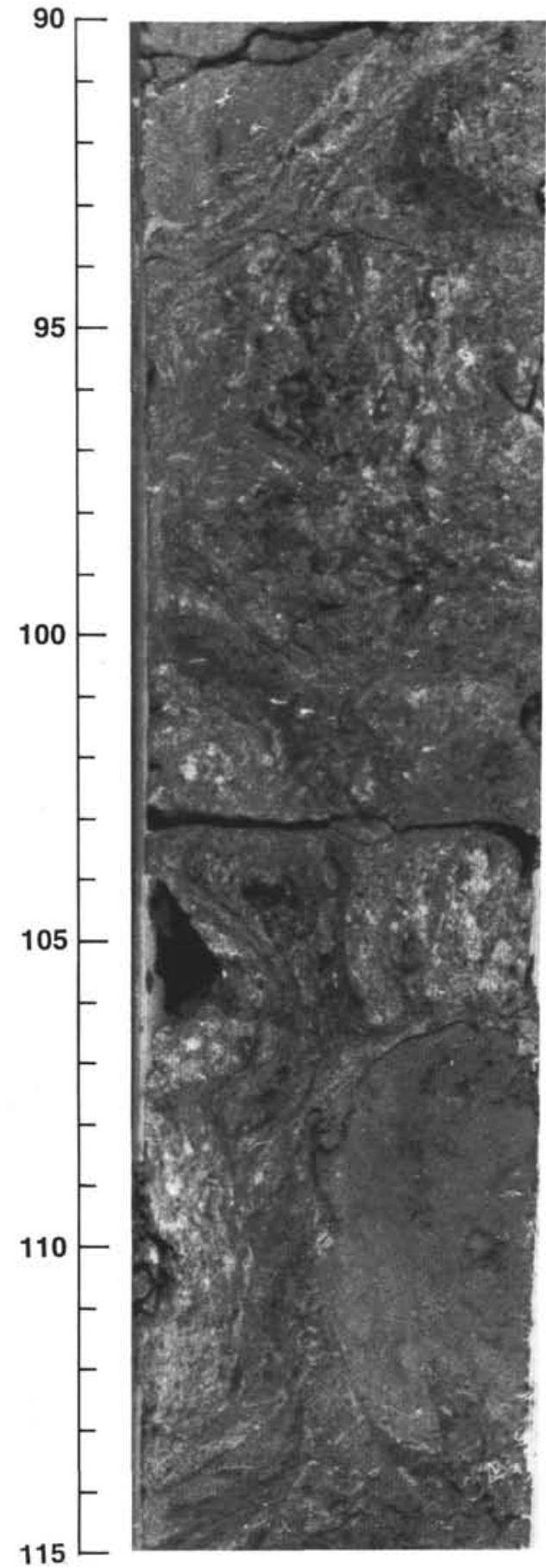

Figure 8. Photograph of Core 134-827B-13R-5, 90-115 cm, showing tectonized micaceous carbonate unit of early or middle Pleistocene age; evidence of possible thrusting.

less than $120 \mathrm{~m}$ of deformed Cenozoic sediment (Figs. 9 and 10) that has been scraped off of the North d'Entrecasteaux Ridge. This accretionary complex resulted from the collision of the North d'Entrecasteaux Ridge and the central New Hebrides Island Arc. Although the décollement may not have been penetrated at Site 829, much of the accretionary complex in the subduction zone where the ridge collides with the arc was cored.

Cores from Site 829 indicate that deformation within the accretionary complex is concentrated along major thrust zones marked by intervals of cataclasite ranging in thickness from a few centimeters to
$3 \mathrm{~m}$ (Meschede and Pelletier, this volume; Figs. 11 and 12). Preferential thrusting may occur along clay layers, as many of the thrust planes are marked by brown clay (Reid et al., this volume; Meschede and Pelletier, this volume; Fig. 13). This suggests that where pelagic and hemipelagic clay layers are present on the downgoing plate, shearing along these bedding planes may cause numerous thrust sheets to form.

Sediment in the imbricated thrusts at Site 829 is similar to sediment deposited on the North d'Entrecasteaux Ridge at Site 828 (Figs. 9 and 10). The sediment consists mainly of upper Pliocene(?) to Pleistocene volcanic siltstone and Oligocene chalk or chalk-like firm ooze; most of the Miocene section is missing. Thin (less than 10-m-thick) intervals of lower Pliocene and upper Eocene carbonate sediment were also recovered at both sites. Igneous rocks recovered in breccias and conglomerates at Sites 829 and 828 are similar in geochemical compositions (Coltorti et al., this volume), suggesting that volcanic rocks of the North d'Entrecasteaux Ridge are also incorporated into the accretionary complex.

Drilling at Site 829 recovered a variety of igneous rocks, including basalts, and probably comagmatic dolerites and gabbros, plus rare ultramafic rocks. Geochemical features, including $\mathrm{Pb}$ isotopic ratios, of the mafic rocks are intermediate between mid-ocean ridge basalts and island arc tholeiites, and these rocks are interpreted to be backarc basin-type basalts and their subvolcanic counterparts. No correlates of these mafic rocks are known from Espiritu Santo and Malakula islands, nor do they occur in the Pleistocene volcanic breccias at Sites 827 and 830 . However, basalts with very similar trace element and isotopic compositions have been recovered from the northern flank of the North d'Entrecasteaux Ridge at Site 828. It is proposed that igneous rocks drilled at Site 829 represent material from the North d'Entrecasteaux Ridge accreted onto the over-riding Pacific plate during collision.

Site 830

Site 830 is located where the South d'Entrecasteaux Chain is colliding with the arc, on the upper forearc slope (Fig. 14). A series of east-dipping reflectors that exists at this site, and two strong reflectors, one at $1.5 \mathrm{~s}$ and another at $2.0 \mathrm{~s}$ (two-way traveltime), were the objectives of drilling (Fig. 15). These reflectors were interpreted by Fisher (1986) as stratigraphic horizons, disrupted by thrust faults that represent carbonate blocks or a debris apron of the subducted eastern part of the Bougainville Guyot. Because of an unstable hole, we were unable to reach these deeper reflectors and test the hypothesis that they represent guyot fragments. Apparently the most intensely deformed area is directly east of the impact zone where an anticlinal dome is succeeded to the east by a series of imbricate thrust sheets (Fig. 14). These sheets gently dip east as shown in seismic reflection profile 01 (Fig. 15). Site 830 is just east of the anticlinal dome west of the toe of the most western or structurally lowest thrust sheet.

Sedimentary rocks penetrated by the drill at Site 830 were derived from the island arc. Rocks found in the undated lithostratigraphic Unit II of Hole 830B have similar petrology to the coarse volcaniclastic breccia of the lower Miocene rocks southwest of Espiritu Santo. The cataclasite (Fig. 16) above the $1.5 \mathrm{~s}$ reflector seen in the seismic reflection profile suggests a shear zone, perhaps associated with a bedding plane along which some forearc shortening has occurred.

\section{Site 831}

Drilling of the Pleistocene to Oligocene lagoonal carbonate rocks and sediment on top of the andesite volcanic basement of the Bougainville Guyot (Site 831; Fig. 14) revealed a chronostratigraphy that is used to fix the Neogene convergence rate in the region (Quinn et al., this volume; Taylor et al., this volume). The deposition and erosion of the carbonate sedimentary rock on top of the guyot as it passed across the outer rise lithospheric flexure of the New Hebrides Island Arc doc- 
umented the vertical and lateral transport of the guyot as it was carried by the Australian (Australia-India) Plate to its present position against the forearc slope. By using the chronostratigraphy of the carbonate cap, Taylor et al. (this volume) was able to determine Quaternary convergence rates with the use of $\mathrm{Sr}$ isotopes. Quinn et al. (this volume) provided tempororal constraints on the deposition of carbonates, which was used along with $U$-series ages, to date the carbonate sequence and to reconstruct the vertical movement of the guyot.

Drilling at Site 831 revealed $727.5 \mathrm{~m}$ of carbonate rock overlying Bougainville Guyot's andesitic basement. The carbonate cap includes $20 \mathrm{~m}$ of pelagic carbonate overlying $707.5 \mathrm{~m}$ of neritic carbonate. Quinn et al. (this volume) subdivided the chronostratigraphy into three intervals consisting of (1) a $189.6 \mathrm{~m}$ (102.40-391.11 mbsf) Pleistocene interval, (2) a 259.24 m (410.31-669.53 mbsf) Miocene interval, and (3) a $48.67 \mathrm{~m}$ (678.83-729.50 mbsf) Oligocene interval. The neritic section is comprised of largely unaltered aragonite sediment that overlies a totally calcitized limestone. The deeper part of the calcitized interval has been pervasively altered by diagenesis (Quinn et al., this volume).

The $\mathrm{Sr}$ isotopic data of Quinn et al. (this volume) indicate that sediment accumulation events (relative sea-level rise) are separated by periods of nondeposition (relative sea-level fall) on the Bougainville Guyot. Relative sea-level fall allows for diagenetic alteration and, at times, removal of sediment, and are recognized as disconformities within the $\mathrm{Sr}$-isotope stratigraphy (i.e., stratigraphically abrupt decreases in $\delta^{87} \mathrm{Sr}$ ). This decrease in $\delta^{87} \mathrm{Sr}$ most likely result from subaerial exposure.

An abrupt change from aragonite-rich sediment to completely calcitized sediment is found in the early Pleistocene interval at about 338 mbsf (Quinn et al., this volume). Taylor et al. (this volume) used this change to indicate the time the guyot was emergent while riding over the outer rise of the lithospheric flexure. A strontium age of $1.42 \mathrm{Ma}$ for a sample recovered at $352.35 \mathrm{~m}$ was used to obtain the time the guyot was emergent. Thus, the approach of the guyot to the arc was used to determine relative convergence rates between the arc and the Australian (Australia-India) Plate. Taylor et al. (this volume) state that since the relative convergence motion between the Australia and Pacific plates is $8.8 \mathrm{~cm} / \mathrm{yr}$ (Demets et al., 1990), the average net convergence rate of $\sim 14-16 \mathrm{~cm} / \mathrm{yr}$ must occur at the latitude of the central New Hebrides Island Arc, thus requiring 10 to 12 m.y. for the North Fiji Basin to open.

The basement of Bougainville Guyot consists of andesitic hyalobreccias derived from a submarine arc volcano. These andesites have low-K affinities and trace element and isotope systematics that indicate only a very minor involvement of large ion lithophile element (LILE)- and ${ }^{87} \mathrm{Sr}$-enriched, slab-derived fluids in their petrogenesis. They have a minimum age as determined by K/Ar dating of $37 \mathrm{Ma}$ (Rex, this volume), and agree with the previous suggestion (Daniel et al., 1977; Maillet et al., 1983) that Bougainville Guyot forms part of an Eocene proto-island arc developed along the southern side of the DEZ above a southward-dipping Benioff zone.

\section{Intra-arc Basin}

Sites 832 and 833 were located in the North Aoba Basin. Site 832 is located on the flat basin floor at 3089.3 meters below sea level (mbsl) in the north-central part of the basin (Fig. 3). Site 833 is located on the northwestern flank of Maewo Island, at $2629.0 \mathrm{mbsl}$ (Fig. 3).

The North and South Aoba basins were first described as a single inter-arc basin (Karig and Mammerickx, 1972) and later as a late-stage extensional feature (Luyendyk et al., 1974). Ravenne et al. (1977) considered these basins to be part of a nearly continuous "median sedimentary basin" along the island arc. Carney and Macfarlane (1980) described the two basins as an asymmetrical intra-arc basin containing thick deposits of Miocene to Pliocene sediment. Katz (1981) estimated a sedimentary fill more than $2 \mathrm{~km}$ and suggested that each basin contains different rock types deposited under different sedimentary conditions, ranging from near open-ocean to enclosed, restricted basins.

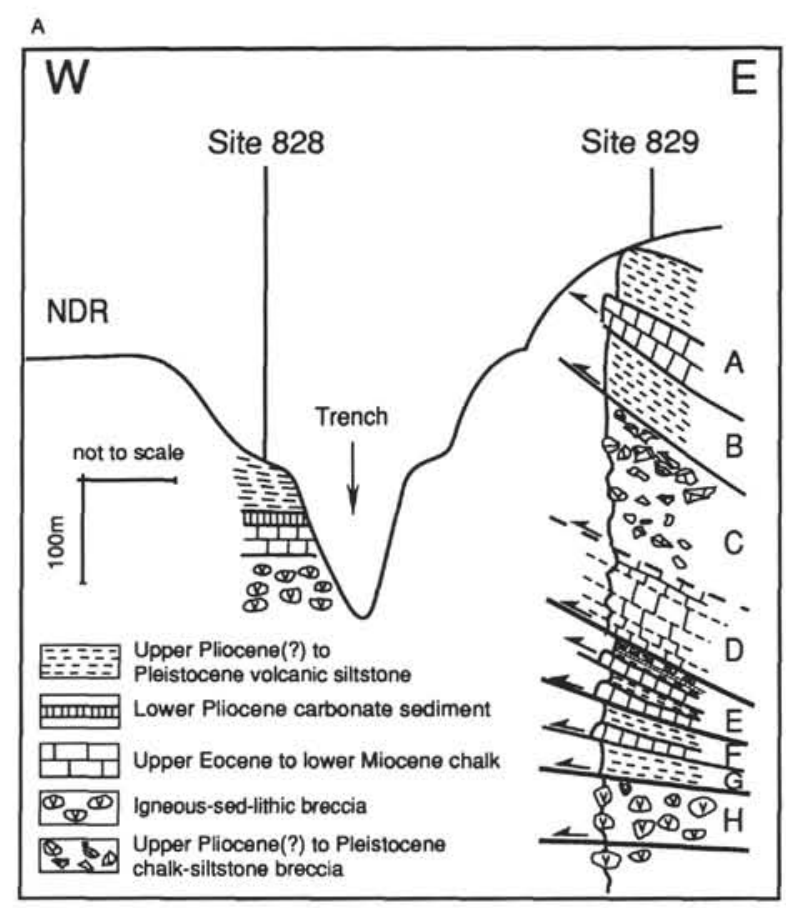

B

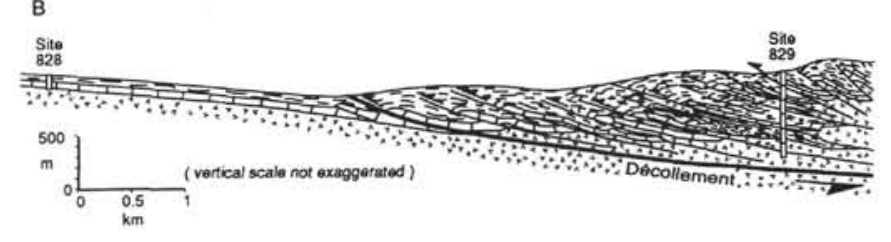

Figure 9. Schematic representation of accreted material in the North d'Entrecasteaux Ridge (NDR)-New Hebrides Island Arc collision zone. A. Relationship of ridge (Site 828) stratigraphy with forearc (Site 829) stratigraphy. B. Detailed sketch of accretionary wedge (after Meschede and Pelletier, this volume).

Gravity and seismic refraction data indicate that the North and South Aoba Basins formed on 8- to 9-km-thick crust, and furthermore that the igneous crust of the basins may have originated either as a trapped piece of oceanic crust, or from island arc crustal thinning by extension (Collot and Fisher 1988). The North Aoba Basin is filled with at least $5 \mathrm{~km}$ of sediment (Holmes, 1988). In the central part of the basin, seismic reflection profiles (Fisher et al., 1988; this volume; Greene and Johnson, 1988) do not show acoustic basement, and the depth of the basin cannot be determined from these data (Fig. 17). However, Pontoise et al. (this volume) estimate a maximum thickness of about $4 \mathrm{~km}$, based on ocean-bottom seismograph refraction studies.

The North Aoba Basin has been described as a half-graben, tilted to the east (Katz, 1988; Fisher et al., 1988), although structure on the islands (Carney and Macfarlane, 1982) and structure mapped along the island shelves and shallow slopes indicate that it is a graben. Collot et al. (1985) described the North Aoba Basin as a downflexed basin and used the model of Chung and Kanamori (1978) to explain the uplift of the Western and Eastern belts of islands and the subsidence of the intra-arc basins. The DEZ collision applied pressure to the western edge of what Chung and Kanamori (1978) modeled as a semi-infinite elastic plate; upward loading due to the buoyancy of the subducting DEZ caused the downward flexing of the Central Basins area and the uplift of the Western Belt only. Collot et al. (1985) refined this model to a finite plate by having the Eastern Belt islands break along faults 

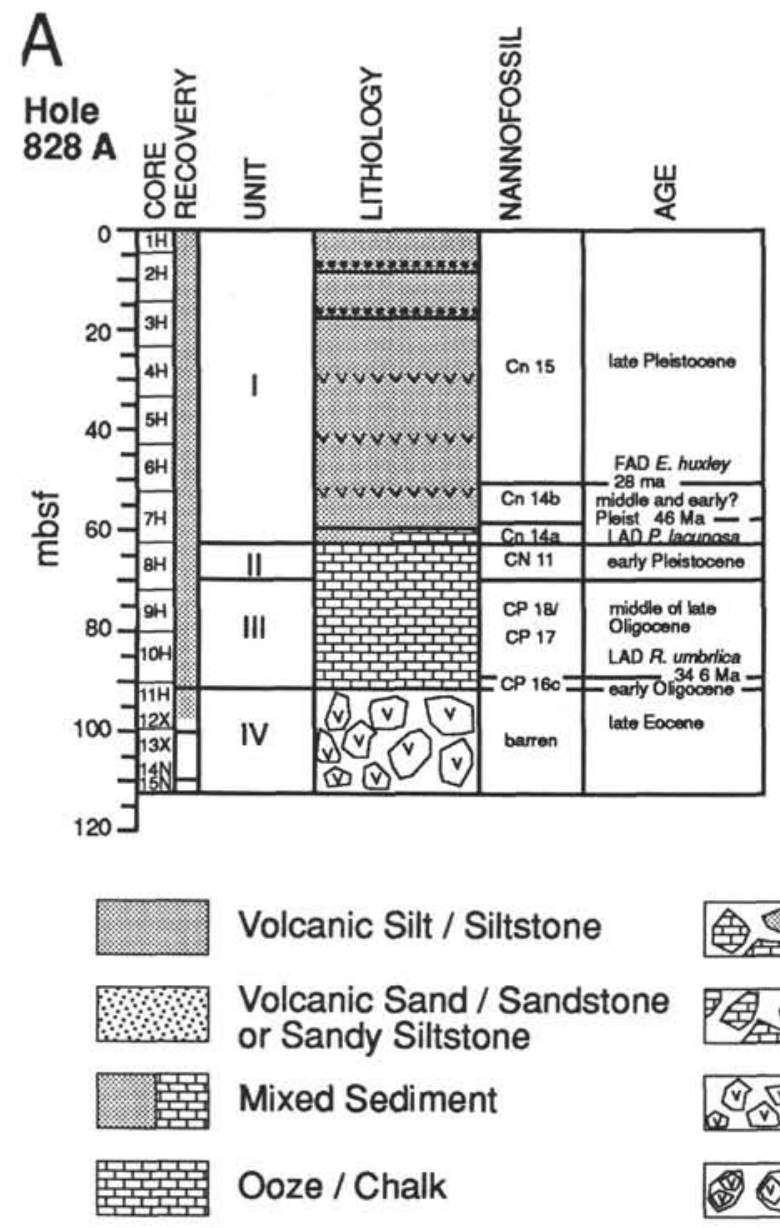
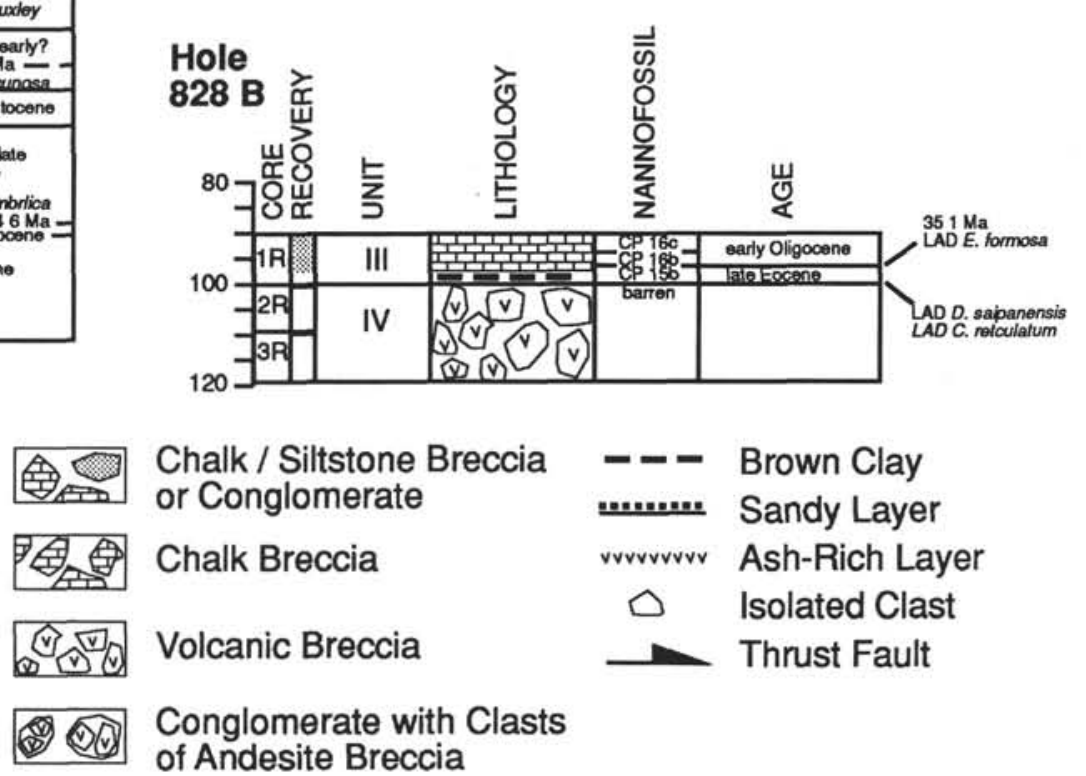

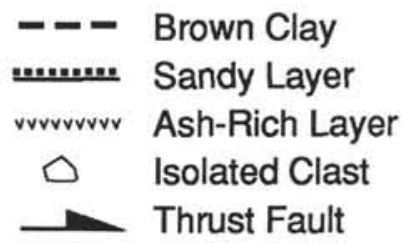

Conglomerate with Clasts of Andesite Breccia

Figure 10. Lithologic columns of (A) Holes 828A, 828B, and (B) 829A showing relationship of thrust sheets with lithologies of the North d'Entrecasteaux Ridge and in the collision zone of the central New Hebrides Island forearc (after Reid et al., this volume). FAD is first appearance datum, LAD is last appearance datum.

along their eastern flanks, which caused these islands to be uplifted as well and to overthrust the adjacent North Fiji Basin as a result of DEZ collision. Geological long-range imaging side-scan sonar (GLORIA) data (Fig. 18; Tiffin et al., 1990) and SeaBeam bathymetric data (Recy et al., 1986) suggest thrust sheets or slumps along the base of the eastern flank of the Eastern Belt. Compressional focal mechanisms from earthquakes and west-dipping slip vectors along the Eastern Belt (Collot et al., 1985; Louat and Pelletier, 1989) suggest that compressive stress is transmitted completely across the arc. Analyses of structural dilation (Krammer et al., this volume) and stress from breakouts (Chabernaud, this volume) substantiate this conclusion.

Many previous authors (e.g., Mallick, 1975; Carney and Macfarlane, 1977; Carney et al., 1985), noted that the central New Hebrides Island Arc is a product of multiple phases of arc evolution. Seismic reflection profiles (Fisher et al., 1988; Greene and Johnson, 1988) indicate that the Central Basins are a product of four (1-4 in Fig. 17) tectonically related sedimentary phases separated by unconformities, although the relationships tend to be more conformable toward the eastern flank of the Central Basins. In addition to the major horsts or upbowed blocks (Western and Eastern belts of islands) and major grabens (North and South Aoba basins), smaller subsidiary fault blocks rose and subsided, alternately allowing erosion and deposition and producing marginal basins to the islands of the Western Belt (Fig. 19).

Erosional and buttress unconformities in the Central Basins attests that vertical tectonism elevated and depressed local hosts and grabens. In addition to the vertical tectonics, transcurrent motion divided the Central Basins through arc-transverse faulting and extrusion of volcanic rocks at Aoba and Ambrym islands (Greene, Macfarlane, John- son, and Crawford, 1988). This segmentation of the Central Basins appears to be the result of the collision of the DEZ with the New Hebrides Island Arc. Onset of the DEZ collision resulted in the uplift of the Western Belt of islands that is reflected in a buttress unconformity (Unconformity 3, Fig. 17) within the Central Basins.

\section{Site 832}

Unconformity 3 (Fig. 17) is thought to represent the approximate time (early Pleistocene) of collision of the DEZ with the arc, and thus was a major objective for drilling at Site 832 . Here, penetration of the unconformity was made near $700 \mathrm{mbsf}$. Uplift of the central part of the Western Belt occurred in response to the collision of the DEZ. However, timing of the uplift and formation of Unconformity 3 are not well constrained, but biostratigraphic analyses of cores from Hole 832B indicate that the hiatus between lithostratigraphic Units IV and V spans an age of from less than $1.89 \mathrm{Ma}$ to more than $1.58 \mathrm{Ma}$ (or 0.31 m.y.) between 654 and $702 \mathrm{mbsf}$, an early Pleistocene age. This correlates with the early to middle Pleistocene or older age given to the oldest thrust fault in the North d'Entrecasteaux Ridge-arc collision zone (Staerker, this volume) and is younger than the late Pliocene or early Pleistocene age assigned to acoustic Unit C (Fig. 17). Cores from Site 832 indicate that the sedimentary fill of the North Aoba Basin is the product of island-arc volcanism, reef erosion, and pelagic deposition.

The clayey foraminiferal and nannofossil limestones interbedded with ash and silty volcanic sandstone of the upper part of lithostratigraphic Unit V (acoustic Unit D in Fig. 17), beneath the unconformity, suggests relatively quiet deep-water sediment deposition devoid of 

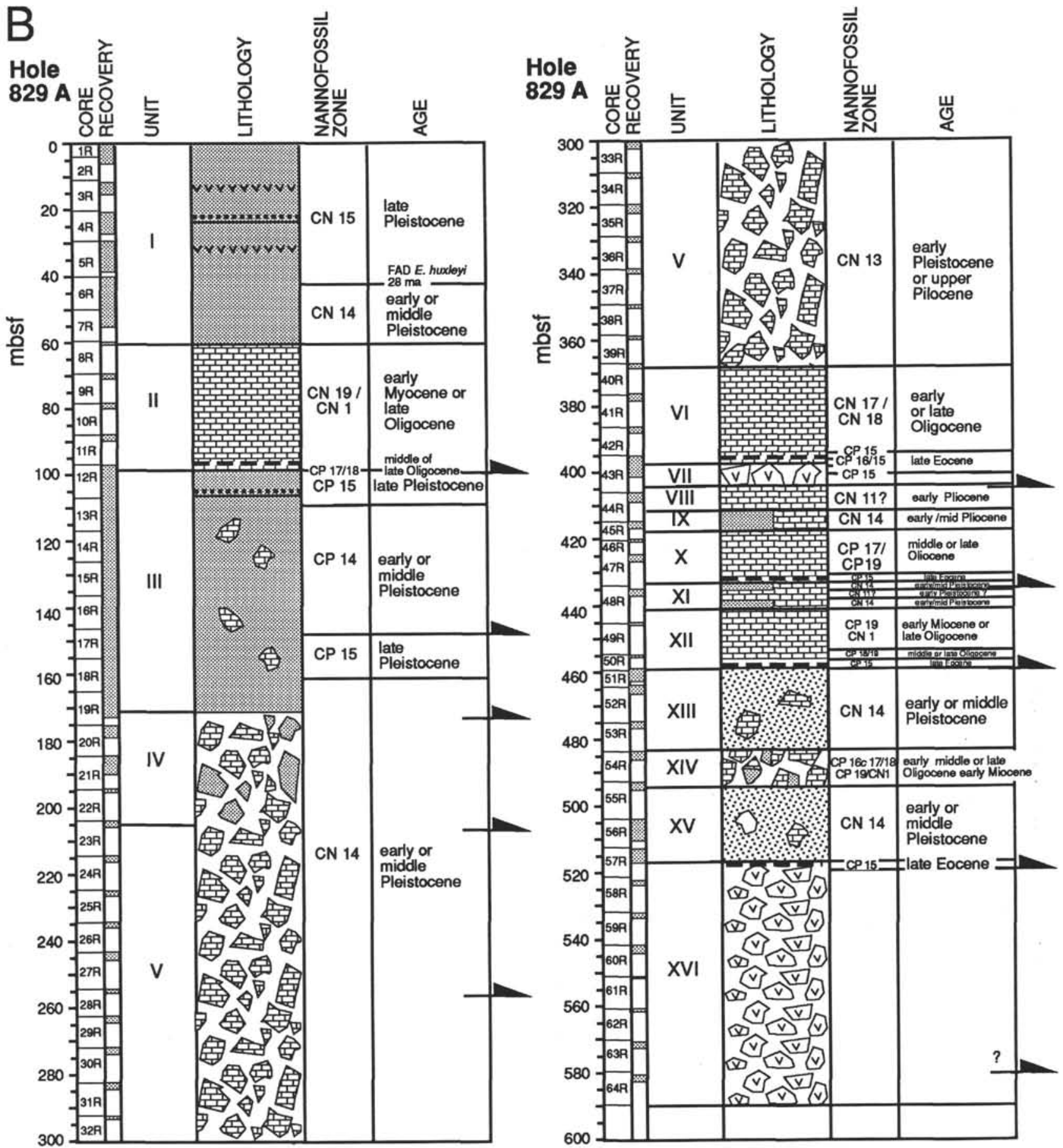

Figure 10 (continued).

coarse-grained volcanic and terrestrially derived material (acoustic Unit C in Fig. 17; Figs. 20 and 21). In contrast, the coarse-grained basaltic breccias of the overlying lithostratigraphic Unit IV suggest uplift of volcanic rocks close to Site 832 .

Lithostratigraphic Unit VII consists of calc-alkaline lavas unlike any recorded from the Central Chain or Eastern Belt but similar to the reported calc-alkaline andesites occurring on Espiritu Santo in the Western Belt (Hasenaka et al., this volume). A K-Ar date of $5.66 \mathrm{Ma}$ for a clast from this unit (Rex, this volume) seems too young in the light of the associated microfossil assemblages for this unit (middle Miocene) and the overlying Unit VI (late Miocene), and probably reflects Ar loss associated with incipient alteration of the dated clast.
Unit VI contains lava clasts essentially similar to the modern Central Chain basalts and andesites, but since Unit VI is late Miocene in age it is likely that this unit is derived from the Eastern Belt. Units IV, III, and II contain clasts that are also compositionally akin to the mediumto high-K basalts and andesites occurring on the adjacent arc volcanoes of Aoba and Santa Maria. Isotopic analyses for clasts from Unit IV indicate a shift towards the strongly "enriched" signature that is shown by Holocene Santa Maria lavas and also by the ashes in Unit $\mathrm{I}$ in Hole 832B. This indicates a commencement of the isotopic compositional shift resulting from DEZ collision, which is probably marked by the major unconformity (unconformity 3 ) at the base of Unit IV. 


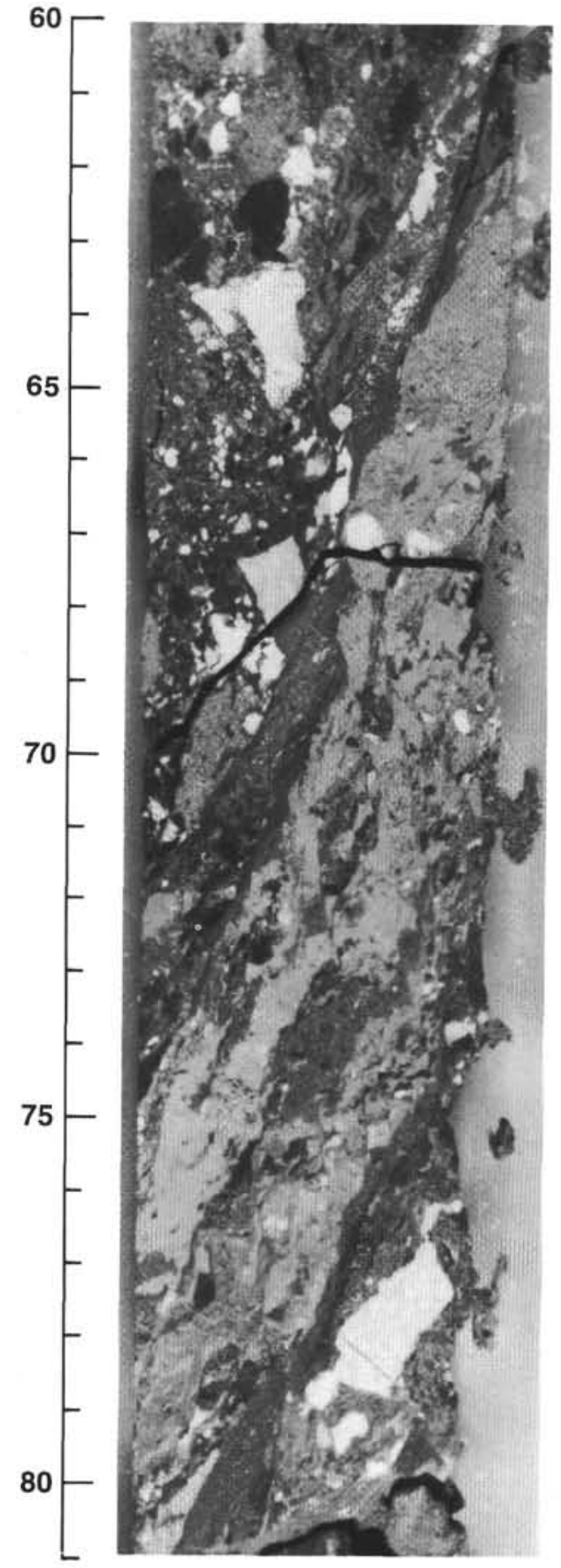

Figure 11. Photograph of Interval 134-829A-2IR-1, 60-81 cm, showing tectonic brecciation in thrust zone.

The upper 385 mbsf (lithostratigraphic Unit I) represents recent (Pleistocene) basin filling from the effusive products of the adjacent Central Chain volcanoes, specifically from Santa Maria and occasional felsic ashes probably from Epi and Tongoa islands (Baker et al., this volume; Gerard and Person, this volume; Briqueu et al., this volume); as well as erosional debris from the Western and Eastern belt islands. The flanks of the basin are covered by unstable Quaternary volcanic ash and pelagic sediment (slumps in Fig. 17; Fisher et al., this volume).

Structural analyses of the cores (Pelletier et al., this volume) indicate that there have been at least two tectonic events, generally correlating with Unconformities 4 (late Miocene) and 3 (early Pleistocene) (Fig. 17). These tectonic events changed the inclination of the

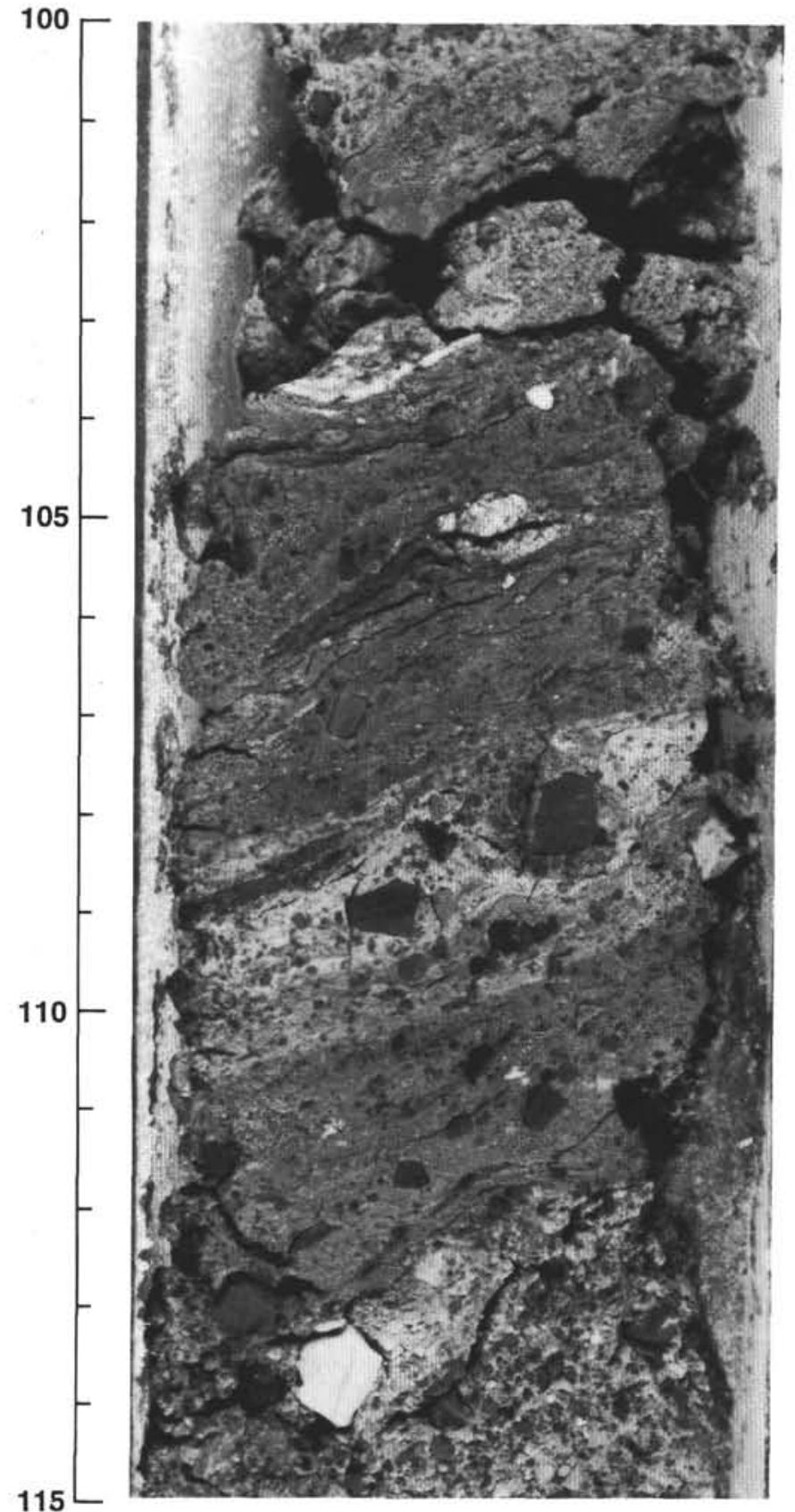

Figure 12. Photograph of Interval 134-829A-58R-1, 100-115 cm, showing shearing of sediment and rock near base of hole.

North Aoba Basin's flanks since late Miocene time, thereby dislodging sediment and forming slumps. These events appear to have been particularly active during the late Miocene and earliest Pleistocene times (Pelletier et al., this volume, their Fig. 5). Although no unconformity was identified between lithostratigraphic Units II and III, a middle Pleistocene disconformity appears to be present as indicated in seismic-reflection profiles (Fig. 17) and by the basal basaltic breccia at the contact between Units II and III. The instability of the western flank of the North Aoba Basin throughout the Neogene is well documented in the cores of Hole 832B (Fig. 22).

\section{Site 833}

Drilling at Site 833 revealed a thick (nearly $400 \mathrm{~m}$ ) Pleistocene volcanic sandstone and ash sequence. Although the sequence is not 


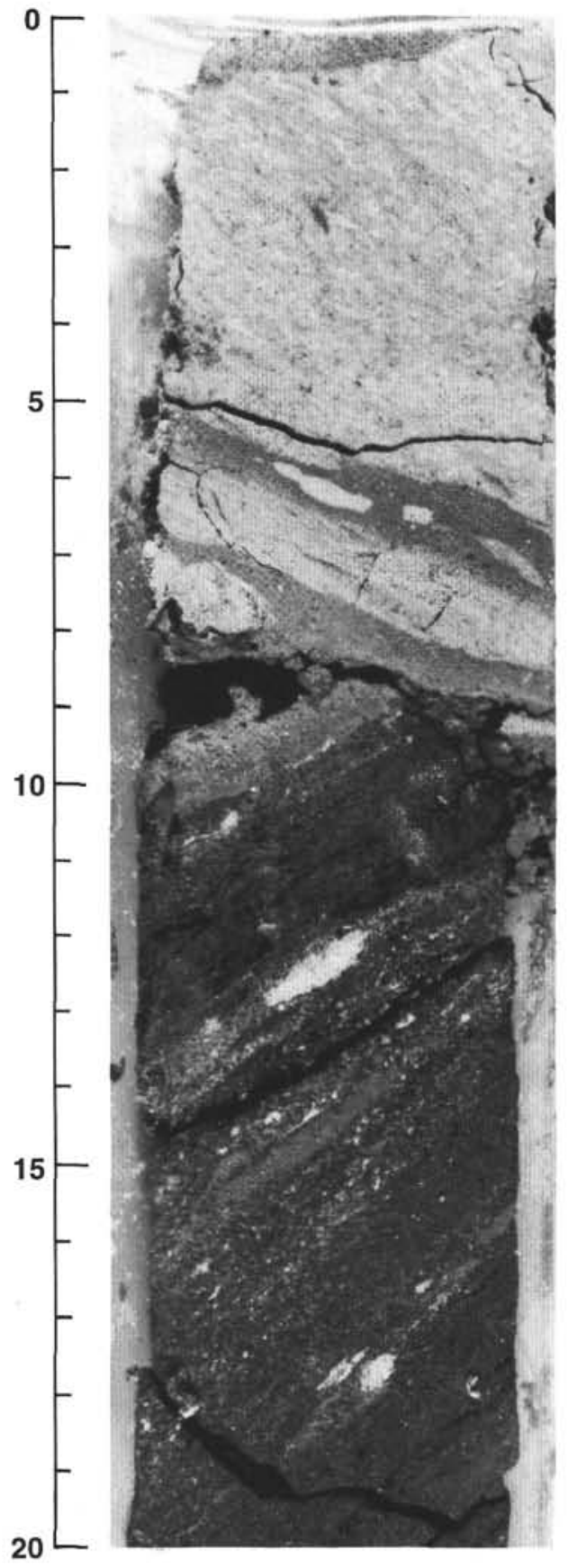

Figure 13. Photograph of Interval 134-829A-51-3, 0-20 cm, showing thrust contact between Oligocene chalk that overlies upper Pliocene or lower Pleistocene calcareous volcanic sandstone. Calcareous brown clay occurs at contact.

as thick as the one drilled at Site 832 (more than $600 \mathrm{~m}$ ), this sequence represents a rapid accumulation of Pleistocene volcanic material and ashes emitted from the active Central Chain volcanoes and erosional products from the adjacent islands. The lithostratigraphic Unit III volcanic breccia drilled at about $400-560$ mbsf suggests uplift and erosion of submarine volcanic rocks compositionally strikingly similar to those on Mare Lava (Hasenaka et al., this volume) and derived from the eastern side of the North Aoba Basin, presumably from mass wasting (slumping and turbidity currents).

In contrast to the 70-m-thick Pliocene sequence found at Site 832, a much thicker (greater than $350 \mathrm{~m}$ thick) Pliocene sequence was revealed at Site 833. Nearly half of the Pliocene sequence at Site 833 is composed of basalt sills that intrude Pliocene sedimentary rocks.

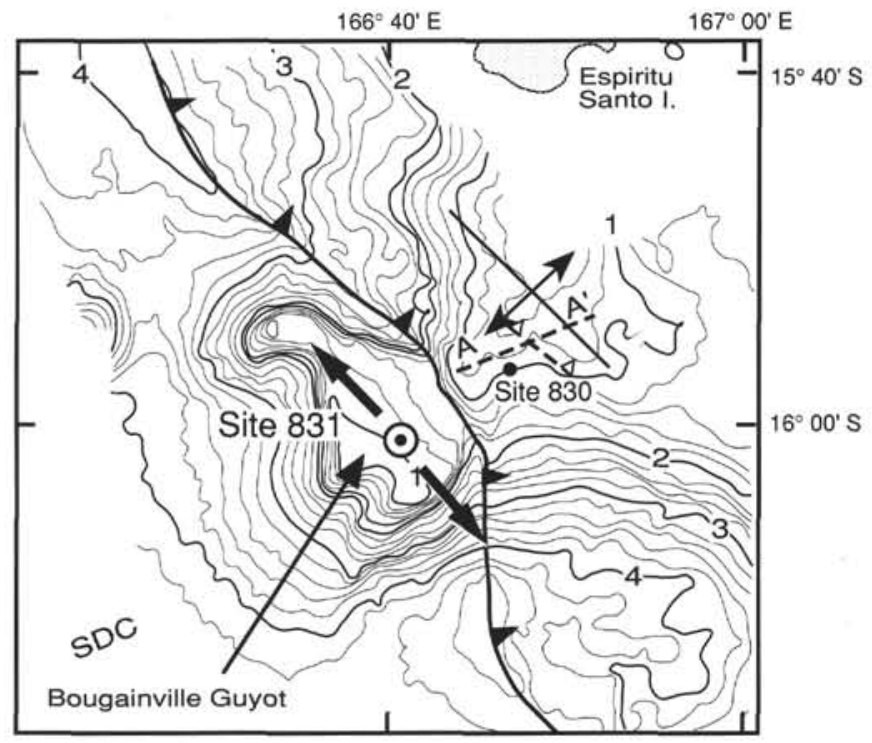

Figure 14. Map showing location of Leg 134 Sites 830 and 831 where the South d'Entrecasteaux Chain (SDC) is colliding with the New Hebrides Island Arc. Heavy barbed line shows seafloor trace of subduction zone and heavy arrows indicate borehole elongation based on BHTV data (Krammer, this volume), which lies nearly perpendicular to convergence direction. Heavy dashed lines with open barbs indicate approximate seafloor trace of thrust faults shown in Figure 15 . Bathymetry contours at $200 \mathrm{~m}$ intervals, numbers indicate depth in $\mathrm{km}$. Dashed bold line shows approximate location of seismic reflection line 01 shown on Fig 15. I. is island.

The sill complex at the base of Hole 833B is important for the interpretation of the petrogenetic history of the arc, as in terms of major and trace elements, it is compositionally akin to basalts and andesites erupted in the modern arc volcanoes of Santa Maria and Aoba. That is, they are relatively high-Ti high- $\mathrm{K}$ to shoshonitic basalts and andesites. However, the sills are isotopically identical to basalts away from the DEZ collision zone, and lack the "enriched" signature of postcollision lavas (Briqueu et al., this volume). As the sills have concordant $\mathrm{K}-\mathrm{Ar}$ ages of 3.3-3.7 Ma (Rex, this volume), they provide a maximum age for the DEZ collision in this part of the arc.

Unit III in Hole 833B contains clasts of unusual low-K composition that have strong compositional similarities to Mere Lava volcano, on the northeastern edge of the North Aoba Basin. It is possible that lavas with similar compositions occur in the Maewo Group, but adequate trace element data are lacking for the extensive volcanic rocks in this formation.

In contrast to Site 832 , fewer large-scale slump features were found at Site 833, although there is evidence (Wong and Greene, 1988) of unstable slopes in the Pleistocene when the Eastern Belt was actively uplifted. Cores recovered at Site 832 also indicate unstable slope conditions (Fig. 23).

\section{DISCUSSION}

Drilling during Leg 134 provided new evidence for constraining the rates of relative plate motion at the eastern Australian (AustraliaIndia) Plate boundary and fixing the time of collision of the DEZ with Espiritu Santo Island. In addition, the working tectonic model for the evolution of the New Hebrides Island Arc was refined by constraining late Tertiary tectonic events. The working tectonic model is briefly stated below; a more detailed description follows.

Magnetic anomalies and SeaBeam maps of parts of the North Fiji Basin (Auzende et al., 1988) support the hypothesis that at about 10 Ma the Vitiaz Arc was located between the Australian and Pacific plates (Gill and Gorton, 1973; Falvey, 1978; Malahoff et al., 1982; Figs. 6A 


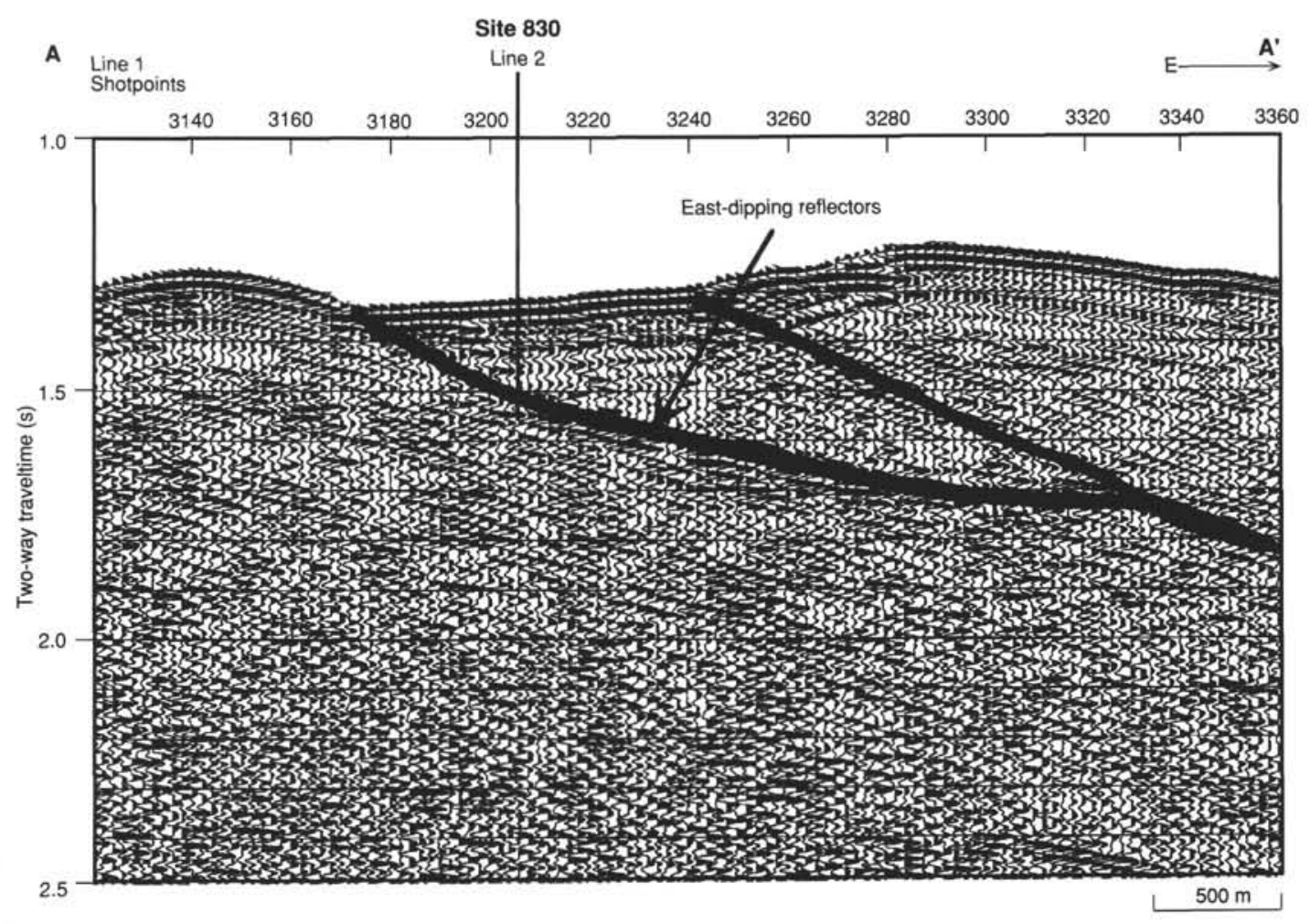

Figure 15. Part of single-channel seismic reflection line 01 that crosses just north of Site 830 showing thrust faults in the vicinity of the drill holes; collected aboard the JOIDES Resolution. Location shown on Figure 14.

and 24A). The Ontong Java Plateau first collided with the Solomon Islands Arc in early Miocene ( $22 \mathrm{Ma})$ with the arc staying inactive until $\sim 10 \mathrm{Ma}$ (Fig. 25). From about 8-10 Ma the Solomon Islands Arc collided with Ontong Java Plateau when subduction of the Australian plate beneath the Pacific Plate began (Kroenke, 1984; Fig. 26A). Consequently subduction direction reversed from southwestward along the Vitiaz Arc to northeastward along the New Hebrides Island and Solomon Islands Arc. This was followed by the opening of the North Fiji Basin along spreading centers, and clockwise rotation of the New Hebrides Island Arc and counterclockwise rotation of the Fiji Islands (Falvey, 1975, 1978; Figs. 6B and 26B). At $\sim 1.5-3 \mathrm{Ma}$, the forearc of the New Hebrides Island Arc appears to have collided with the DEZ (Fig. 26C). At $0.7 \mathrm{Ma}$ rearrangements of the axial spreading zone and the triple junction of the North Fiji Basin occurred (Auzende et al., 1988) and the North Fiji Fracture Zone formed.

\section{Late Oligocene to Early Middle Miocene}

A major geologic event recognized in the central New Hebrides Island Arc is the late Oligocene and early Miocene volcanic eruption of lavas onto the ocean floor, all along the arc (Carney et al., 1985). Block faulting and deposition of volcanogenic sediment into basins adjacent to the arc accompanied the volcanism. Compression at the beginning of the middle Miocene ( 20 Ma), possibly associated with a change in motion of the Australian (Australia-India) Plate, ended volcanism after emplacement of stocks into a wrench-fault system subparallel to the arc (Fig. 26A; Carney et al., 1985). Prior to the opening of the North Fiji Basin, volcanism was active along the Western Belt during latest Oligocene to early middle Miocene ( 25-14 $\mathrm{Ma}$; Fig. 25) as indicated by 25 -m.y.-old volcanic rocks from the Torres Islands (Carney and Macfarlane, 1978, 1982; Carney et al., 1985) and a $\mathrm{K} / \mathrm{Ar}$ age as old as $21 \mathrm{Ma}$ from volcanic rocks on Espiritu Santo and Malakula islands (Gorton, 1974; Mitchell, 1971; Carney and Macfarlane, 1982; Carney et al., 1985). During this time, the Western
Belt was shallowly submerged in general but locally emergent and reef fringed. On the Cumberland Peninsula (Fig. 5) of Espiritu Santo large allochthonous limestone blocks slumped down into a small marginal basin, indicating fairly steep slopes and the basin's close proximity to carbonate platforms (Greene, Macfarlane, Johnson, and Crawford, 1988). Limestone blocks from this same area appear to have been carried even further down the slope into the yet to form intra-arc North Aoba Basin as noted by Fisher et al. (this volume).

\section{Middle Miocene Time}

During the middle Miocene ( $14-11 \mathrm{Ma})$ volcanism ceased along the Western Belt suggesting that subduction at the Vitiaz Trench may have slowed causing the emergence of the Western Belt (Macfarlane et al., 1988; Greene, Macfarlane, Johnson, and Crawford, 1988). East of the Western Belt, a late middle Miocene phase of normal faulting formed grabens, and volcanogenic sediment was deposited into these basins directly (Fig. 24B). At that time, the Eastern Belt islands was the site of deep-water sedimentation and deposition of terrigenous clasts derived from an uplifted (emergent) and eroding volcanic Vitiaz Arc to the northeast. Initial sedimentation was, therefore, contemporaneous with tholeiitic eruptions onto the Oligocene(?) North Fiji Basin ocean floor in the vicinity of the Eastern Belt (Fig. 24B; Macfarlane et al., 1988), which are now exposed as ophiolites on Pentecost Island.

Detritus generated by mass wasting along the emerging flanks of Espiritu Santo Island and areas to the northwest was transported down the eastern slopes into the proto-North Aoba Basin where they were deposited as graywackes (Macfarlane et al. 1988; Greene, Macfarlane, Johnson, and Crawford, 1988). From this area sediment was supplied to the channeled-fan complex described by Fisher et al. (this volume) that lies just beneath the bottom of Hole 832B. Seismic reflection data, suggest that slumped reef rocks are incorporated into the fan deposits (Fisher et al., this volume). Furthermore, geochemical data for clasts 
in lithostratigraphic Unit VII indicate that they have calc-alkaline affinities, and are almost certainly derived from exposed Western Belt rocks on Espiritu Santo. A middle Miocene unconformity on Espiritu Santo Island (Macfarlane et al., 1988) indicates a major erosional event during that time, but whether the erosion resulted from tectonic uplift or from sea level drop is speculative. Pigram et al. (1992) estimate from cores drilled on the Great Barrier Reef (ODPLeg 133) that during the middle to late Miocene sea level fell $180 \mathrm{~m}$. This regional fall in sea level could be recorded in low-standing islands of the southwest Pacific.

\section{Early Late to Middle Late Miocene}

In early-late to middle-late Miocene time ( 11-8 Ma), the tectonic regime along the Western Belt switched from tension to compression and the entire region underwent active structural flexuring and uplift, as indicated by the paucity of sediment of this age and by an irregular topography (eroded, unconformable surface and transverse folding) on Espiritu Santo Island and reverse faulting and folding on Malakula Island (Carney and Macfarlane, 1982; Macfarlane et al., 1988; Greene, Macfarlane, Johnson, and Crawford, 1988). The entire Western Belt was emergent at this time, yet with the exception of an enigmatic volcanism on the southeast part of Malakula dated at 10.7-7.5 Ma (Gorton, 1974), no volcanic activity occurred (Kroenke, 1984; Carney et al., 1985; Macfarlane et al., 1988). Strong coupling between the newly subducting Australian Plate and the new Pacific/North Fiji Basin probably caused uplift of the Western Belt. Folding and transverse wrench faulting occurred, and subduction at the Vitiaz Trench appears to have ceased (Fig. 24C). Compressional deformation is speculatively based on the terrigenous pelagic Red Mudstone Formation against the Matanui Group of volcanic rocks of northwest Malakula Island that also took place in early to middle late Miocene time (Carney and Macfarlane, 1982; Fig. 5). Uplift did not occur along the Eastern Belt during the middle to late Miocene, as evidenced by middle Miocene terrigenous sediment derived from the Vitiaz Arc that is conformably overlain by upper Miocene pelagic sediment on Maewo and Pentecost (Carney and Macfarlane, 1982; Carney et al., 1985; Macfarlane et al., 1988).

In the Central Basins region, deep-water deposition occurred; sediment eroded from the Western Belt was deposited along the site of the Eastern Belt as the Tafwutmuto Formation of central Maewo (Greene, Macfarlane, Johnson, and Crawford, 1988; Fig. 5). Submarine volcanism active at the site of the Eastern Belt as indicated by $\mathrm{K} / \mathrm{Ar}$ dates of $7 \mathrm{Ma}$ on Maewo Island (Macfarlane et al., 1988) and 6-3 Ma on Pentecost Island (Mallick and Neef, 1974; Gorton, 1974).

Opening of the North Fiji Basin and westward displacement rotated the New Hebrides Island Arc beginning sometime between about 8 and $12 \mathrm{Ma}$ (Auzende et al., 1988; Taylor et al., this volume), when the Solomon Islands Arc collided with the Ontong Java Plateau (8-10 Ma) and the Vitiaz subduction ceased (Kroenke, 1984). Western Belt rocks migrated westward, rotating in a clockwise fashion from a pole somewhere north and east of Erromango (Musgrave and Firth, 1993), and splitting away from Fiji and Tonga, with Fiji rotating anti-clockwise (Figs. 6A and 26). Extensional tectonics associated with the opening of the North Fiji Basin during the late Miocene brought about subsidence of the Western Belt and new arc volcanism along the Eastern Belt, which was built upon the ocean floor of the North Fiji Basin (Fig. 24D).

\section{Late Miocene to Pliocene}

The earliest known eruptions along the Central Chain occurred on Erromango ( 5.8 Ma, Colley and Ash, 1971; Bellion et al., 1984). Penecontemporaneous with volcanism along the Eastern Belt during the late Miocene were volcanic eruptions on Vot Tande (Ash et al., 1980) and south of Futuna, along the scarps and floors of the Coriolis Trough (Dugas et al., 1977), during the middle Pliocene (Fig. 24E).

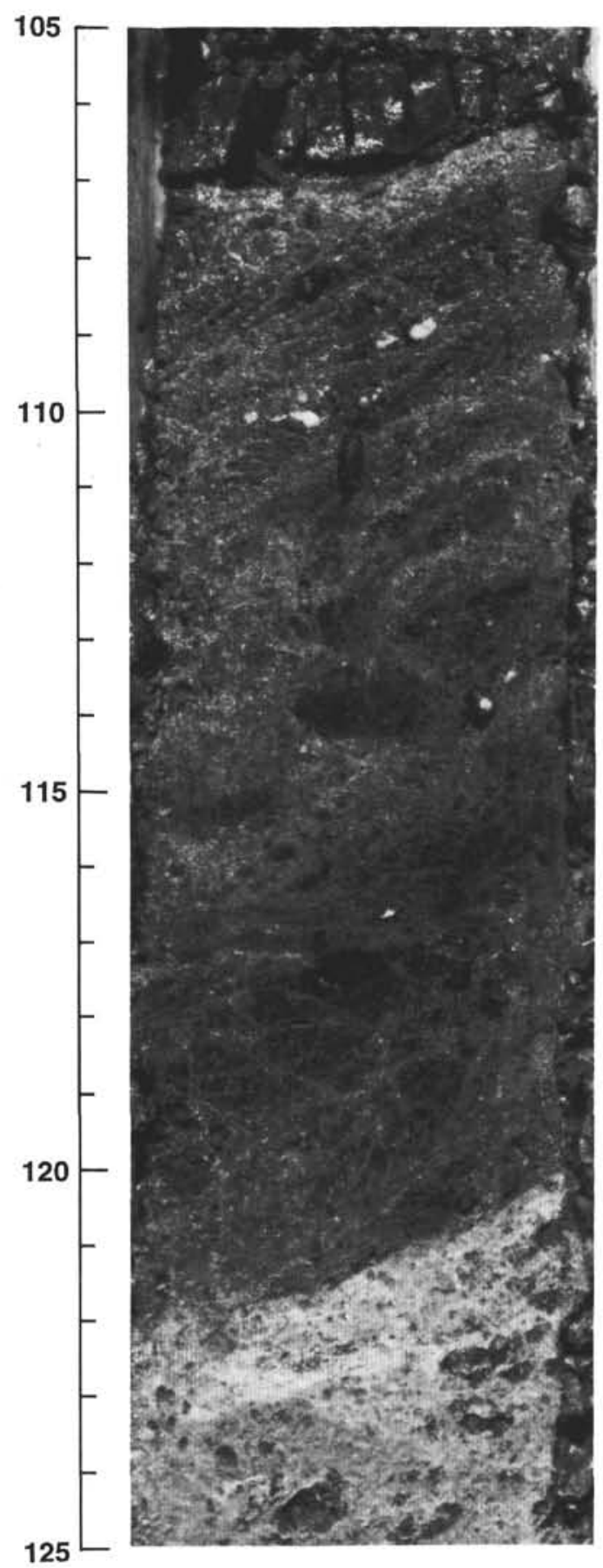

Figure 16. Photograph of Interval 134-830B-20R-1, 105-125 cm, showing cataclasite near bottom of hole.

Volcanism during the Pliocene ( 5-2 Ma) was short-lived, appearing to have ceased along the Eastern Belt, ceased first on Maewo ( $\sim \mathrm{Ma})$ and then shifted to the Central Chain with volcanic activity occurring along Central Chain islands south of Efate (Ash et al., 1980; Macfarlane et al., 1988). However, basaltic sills (Hole 833B) indicate that magmatic injection occurred along the western flank of Maewo Island during this time as well, based on $\mathrm{K} / \mathrm{Ar}$ dates of $3.30 \pm 0.4$ and 3.65 $\pm 0.30 \mathrm{Ma}$ (Rex, this volume).

Based on rates of opening $(\sim 6 \mathrm{~cm} / \mathrm{yr})$ as proposed by Taylor et al. (this volume) and an assumed distal end of the DEZ located somewhere near $17^{\circ} \mathrm{S}, 168^{\circ} \mathrm{E}$ (Fig. 26B), we speculate that collision of the DEZ 
Site 832

Site 833

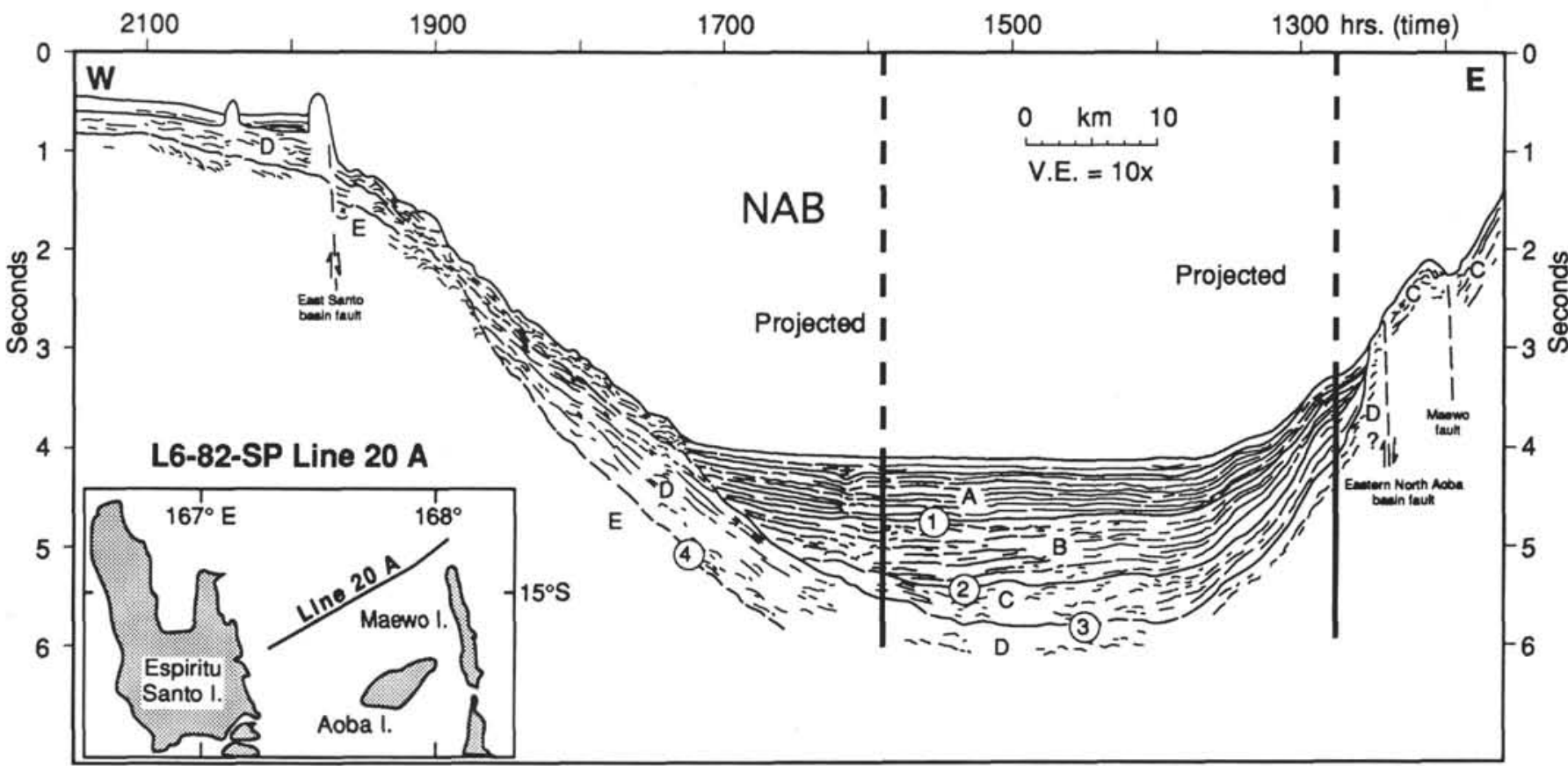

Figure 17. Line drawing of single-channel seismic reflection profile collected across the North Aoba Basin (NAB). See text for definition of units (modified after Greene and Johnson, 1988, and Johnson and Greene, 1988). V.E. is vertical exaggeration, I. is island.

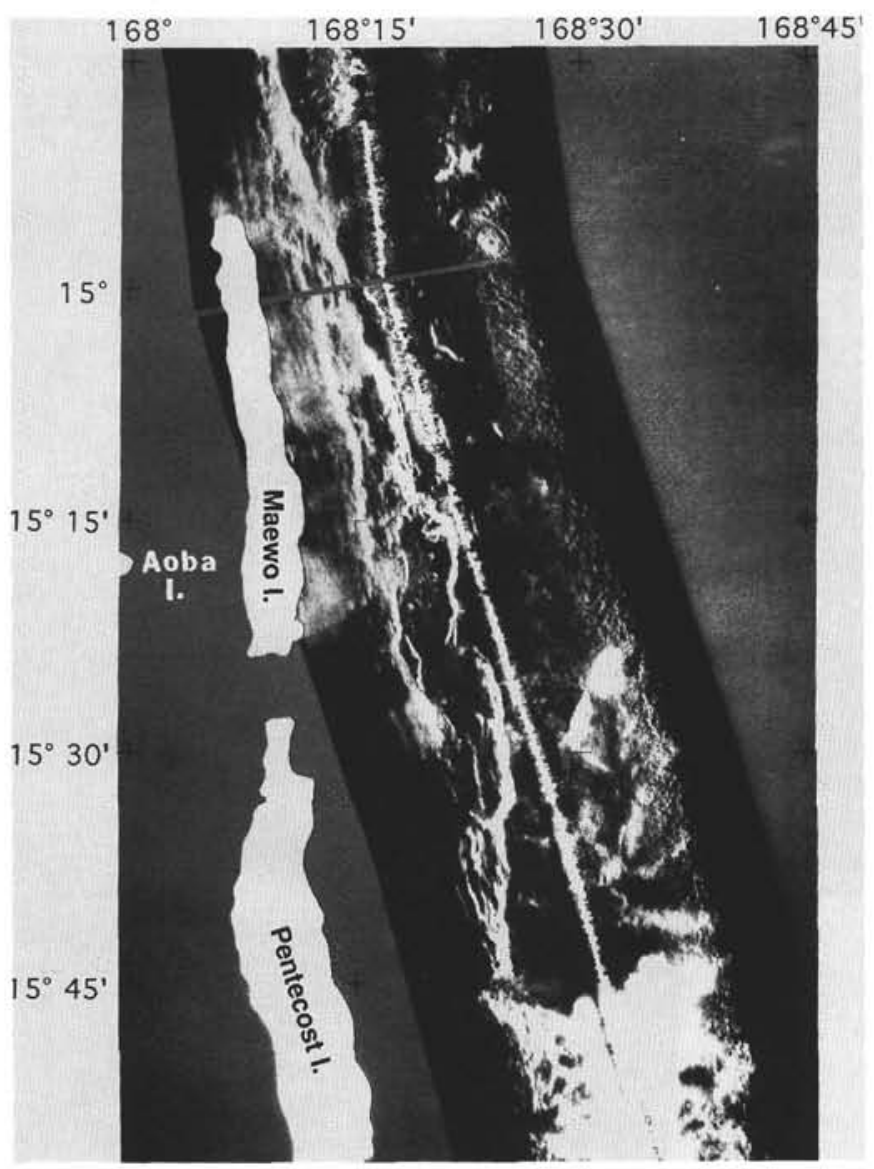

Figure 18. GLORIA image of backarc region of Central New Hebrides Island Arc showing interpreted thrust fault (sinuous high reflective line). Image courtesy of SOPAC (also see Tiffin, 1990; Price et al., 1993). I. is island. proper with the Western Belt island of Malakula occurred during the late Pliocene $(\sim 2-3 \mathrm{Ma})$ and caused uplift of both the Western and Eastern belts, along with emplacement and unroofing of ultrabasic rocks and cessation of arc volcanism on Pentecost Island (Carney and Macfarlane, 1982). Another response to localized compression caused by the DEZ collision was the interruption of the formation of back arc troughs, in contrast to the inception of the Vot Tande and Coriolis troughs north and south of the Central Basins area. The Coriolis Trough evidently started to form between 2.6 and $2 \mathrm{Ma}$ and the Vot Tande Trough formed about $2.8 \mathrm{Ma}$ (Fig. 25), based on volcanic dredge samples and structural considerations by Recy et al. (1990). Large reef-derived carbonate lenses in the pelagic sequence on Espiritu Santo Island suggest that periodic uplift interrupted the general subsidence of the Western Belt during late Miocene and Pliocene (Fig. 24E; Carney et al., 1985).

Extensive marine sedimentation took place during the late Miocene to late Pliocene, and only a few areas were emergent along the central New Hebrides Island Arc. Emergent areas consisted of small areas on Espiritu Santo Island and on Maewo, and a larger area on central Pentecost (Macfarlane et al., 1988; Greene, Macfarlane, Johnson, and Crawford, 1988). Globigerina oozes and calcareous sediment of the Marino and Nasawa Formations (Fig. 5) on and around northern and central Maewo Island, and the Raga Group carbonates of Pentecost Island indicate that subsidence and deposition on the Eastern Belt took place during this time. Calcarenites of the Tawoli Formation on Espiritu Santo and sandstone and siltstone of the Malua and Wintua Formations on Malakula indicate shallow-water deposition on the Western Belt during the late Miocene to Pliocene (Macfarlane et al., 1988; Fig. 5).

In the developing intra-arc (North and South Aoba basins) basin, turbidite and debris flow deposition and deep pelagic sedimentation occurred, and volcanic ash began to accumulate within the intra-arc basins. Of the two sites drilled in the North Aoba Basin, Site 832 (lithostratigraphic Units VI and VII, 866-1101 mbsf, Hole 832B) revealed the oldest sedimentary rocks, which are composed of volcaniclastic debris-flow deposits, turbidites, and some hemipelagic sediment (Collot, Greene, Stokking, et al., 1992; Goud Collins, this volume). Calc-alkaline lavas recovered from lithostratigraphic Unit 
VII is similar to calk-alkaline andesites found on Espiritu Santo (Hasenaka et al., this volume). Dates obtained from microfossils in sedimentary rocks of Unit VII ranged from early to middle Miocene, but the microfossils are thought to be reworked (Staerker, this volume; Goud Collins, this volume). However, microfossils give a late Miocene age for sedimentary rocks of Unit VI. A basaltic clast was dated at $5.66 \pm 0.85 \mathrm{Ma}$ (Rex, this volume), giving an age of no earlier than latest Miocene for the strata of lithostratigraphic Unit VII (Site 832), but this seems too young in light of the microfossil assemblage and probably reflects Ar loss.

Goud Collins (this volume) interprets these uppermost Miocene units as sediment that was emplaced by debris flow originating in shallow water, with some turbidites originating near Maewo Island, because source rocks of latest Miocene age are exposed on the island and are petrologically similar to the basaltic clast recovered in Hole 832B. However, Pelletier et al. (this volume) proposes that the debrisflow deposits and turbidites of Unit VII originated primarily from the Western Belt because of the existence of a major unconformity of Miocene age on Espiritu Santo and Malakula and flow breccia of similar age on Malakula. Based on the above studies, we interpret Unit VII lavas to have originated from Espiritu Santo and Unit VI sedimentary rock from the Eastern Belt because of its late Miocene age. Santa Maria and Aoba, which are close to Sites 832 and 833 , have exposures of high-K basalts and andesites that are similar to clasts found in Units IV, III, and II. These uppermost Miocene deposits were rapidly supplied to the North Aoba Basin during the initial volcanic build up of the Eastern Belt, which formed the eastern side of the basin. Akimoto (this volume) states that during the early Pliocene ( 5.4 Ma), the North Aoba Basin floor gradually shallowed from below the carbonate compensation depth (CCD), $4500 \mathrm{~m}$, to the lower part of the lower bathyal zone (3400-3500 m; Fig. 27). The lower Pliocene Maewo Group are lower mid-bathyal (1800-3000 m) deposit.

On the basis of new mean northward migration rates $(3.2-4 \mathrm{~cm} / \mathrm{yr}$; Taylor et al. this volume), for the DEZ along the arc, we speculate that in the late Pliocene (2-3 Ma), the earliest collision of the DEZ occurred along the central part of the New Hebrides Island Arc between Epi and Efate islands (Figs. 25 and 26C). Evidence of this collision may exist near Epi Island, where a large bathymetric reentrant is located (Collot and Fisher, 1991) and may be the result of forearc erosion from the subduction of a seamount, perhaps one associated with the South d'Entrecasteaux Chain (Greene, Macfarlane, Johnson, and Crawford, 1988). The North d'Entrecasteaux Ridge would, therefore, at that time, be impinging upon the forearc slope near the southern part of Malakula and southwest of Epi Island (Fig. 26C). Marthelot et al. (1985) and Louat et al. (1988) suggested that the DEZ once curved to the south and Greene, Macfarlane, Johnson, and Crawford (1988) suggested that the southeastern part of the DEZ was first to come into contact with the arc with a seamount deeply indenting the forearc slope and initiating counter-clockwise rotation of Malakula Island. Pascal et al. (1978) proposed that the DEZ today is subducting along a trend of $\mathrm{N}^{\circ} \pm$ $11^{\circ} \mathrm{E}$ with respect to the Pacific Plate and the New Hebrides Island Arc.

During collision of the DEZ with the central New Hebrides Island Arc at Malakula Island, the continued opening of the North Fiji Basin rotated the arc with a hinge located somewhere north and east of Erromango (Musgrave and Firth, 1993), increasing the migration rate of the DEZ to the north, perhaps at fluctuating rates reflecting the changes in opening rates as described by Taylor et al. (this volume). The impact and subsequent subduction of the DEZ caused uplift of Western Belt islands as the DEZ passed by, beginning in the south with uplift of southern Malakula, perhaps associated with the subduction of the seamount that formed the Malakula bathymetric reentrant (Collot and Fisher, 1991), then uplift of northern Malakula, southern Espiritu Santo, and today central and northern Espiritu Santo Island. According to Mallick (1973), Malakula Island experienced greater early deformation, whereas Espiritu Santo Island experienced greater late uplift resulting in higher mountains. This would fit with the collision and

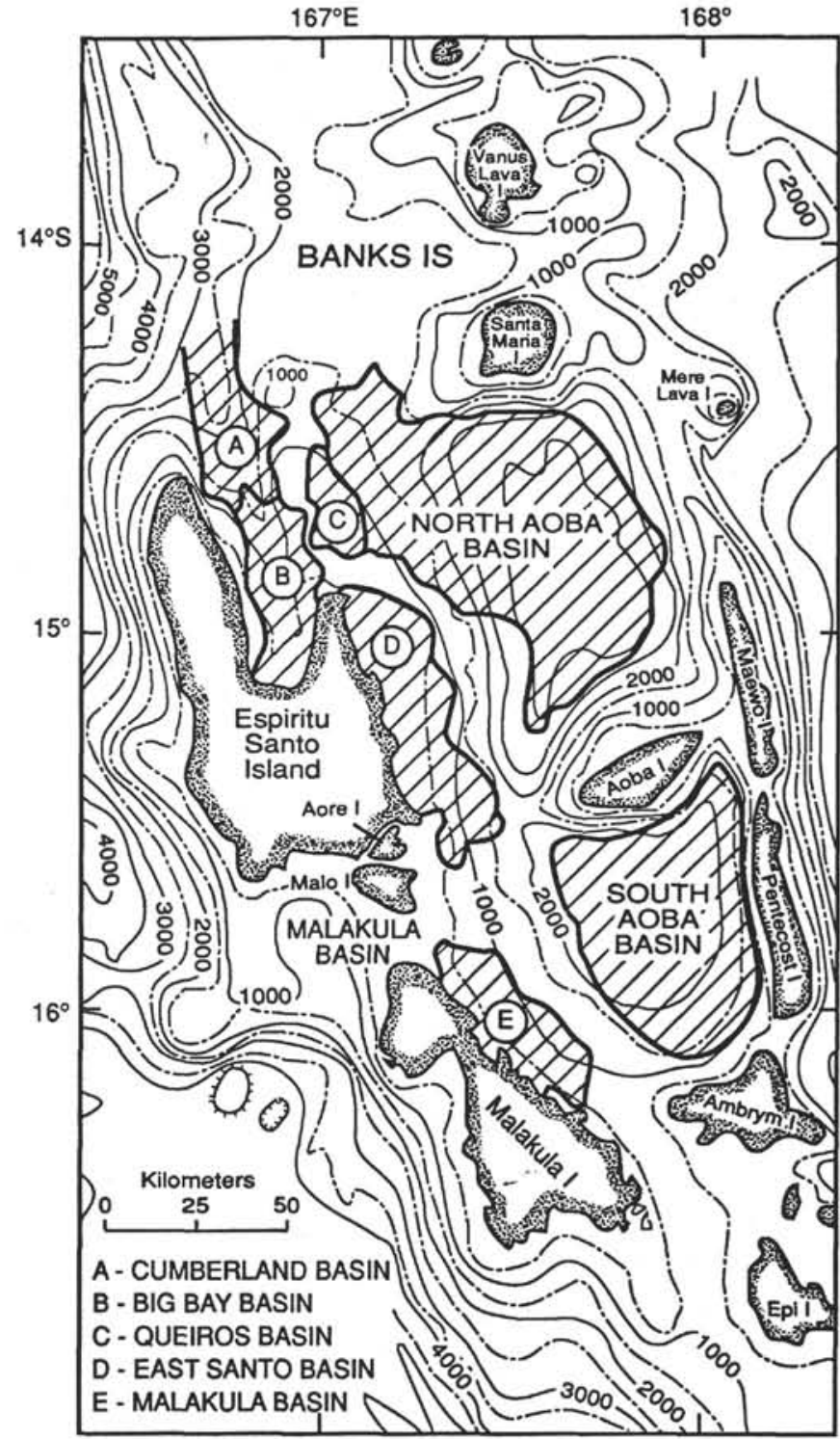

Figure 19. Sedimentary basins of the summit area of the central New Hebrides Island Arc. Bathymetry in meters (after Greene and Johnson, 1988). I is island.

northward passage of the DEZ. Malakula was elevated during collision of the DEZ when the DEZ was directly west of the island, and now is subsiding and eroding because the DEZ has moved on to collide with Espiritu Santo. Malakula Island remained elevated until the early Pliocene time before subsiding when a transgressing sea deposited the Wintua and Malua formations (Macfarlane et al., 1988).

The northward migration of the DEZ progressively deformed the forearc of the central New Hebrides Island Arc through collision and subduction. Greene, Macfarlane, Johnson, and Crawford (1988), Collot and Fisher (1988), and Daniel et al. (1989) suggest that this impact and northward migration of the DEZ fragmented the arc and caused transverse fracture zones to form transverse to the arc. The first to form was the Epi fracture zone; subsequently northward formation of the Ambrym, Aoba, and Santa Maria fracture zones occurred with the northward migration of the DEZ (Fig. 4). These fractures zones eventually tapped mantle magma sources allowing relative fast migration of primitive, picritic magmas to build volcanic islands. In addition, these fracture zones and volcanic intrusions divided the central intraarc basin (Fig. 24F), forming the North Aoba and South Aoba basins. 


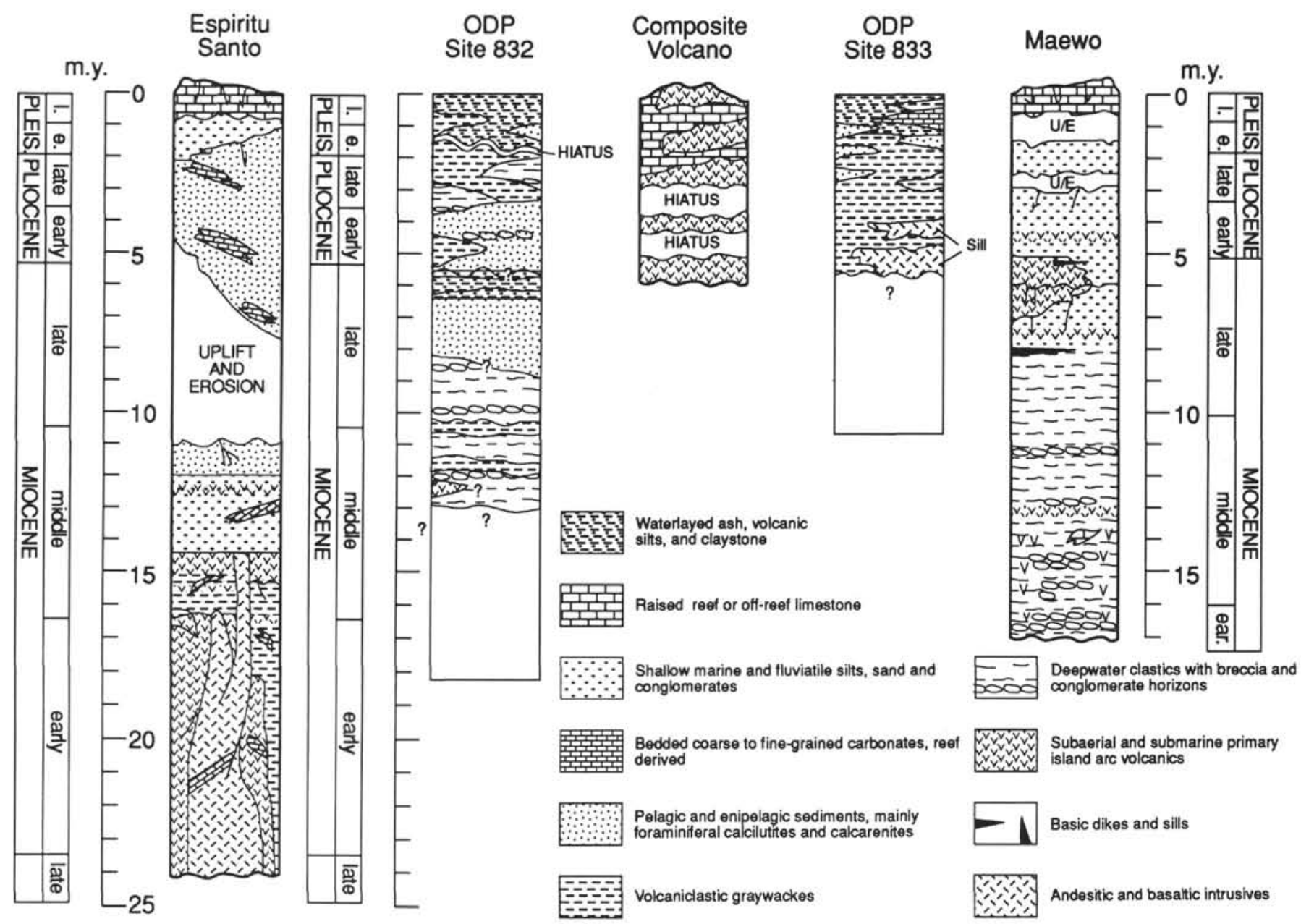

Figure 20. Correlation of stratigraphic columns in the North Aoba Basin based on seismic and drill data collected during Leg 134, and showing relationship of island and basin stratigraphy (modified after Greene, Johnson, Macfarlane, and Wong, 1988, and Fisher et al., this volume). 1. is late, e. and ear. are early.

\section{Latest Pliocene to Early Pleistocene}

During the late Pliocene to early Pleistocene $(\sim 2.0-0.4 \mathrm{Ma})$, the North Fiji Basin continued to spread, with the spreading center initiating northward propagation and pushing both the northern and southern New Hebrides Island Arc further to the west (Musgrave and Firth, 1993; Fig. 26D). Uplift of the Western and Eastern belt islands and onset of full-scale, nearly orthogonal collision of the DEZ and arc accompanied this spreading, and resulted in formation of the present-day central islands of Vanuatu. During the late Pliocene, Central Chain volcanism appears to have been distributed over a much wider belt-at least in the southern part of the arc (e.g., between Erromango, Tanna, and Futuna islands) - than at present; this difference argues for a more gently dipping Benioff zone at that time (Carney et al., 1985; Louat et al., 1988). Continued subduction of the DEZ during the latest Pliocene caused rapid uplift of both the Western and Eastern belts during the Quaternary and formation of the Aoba basins. During the earliest Pleistocene to the present, volcanism at the rear of the summit platform (Futuna Island) slowed, the seismic zone steepened to its present inclination of $70^{\circ}$, and a narrow belt of Central Chain volcanic activity spread along the length of the arc. However, the recently active Mere Lava volcano in the Banks Island Group (Fig. 3 ), which lies east of the present volcanic line, is thought to have originated from magmatism associated with incipient backarc rifting at the Vot Tande Trough (Fig. 24F; Macfarlane et al., 1988).

During the late Pliocene to early Pleistocene, the New Hebrides Island Arc was undergoing uplift, the active volcanic belt narrowed, the Central Basins were accumulating sediment, and rifting and crustal extension occurred in the backarc (Carney and Macfarlane, 1982). These authors also found that this scenario follows Chung and Kanamori's (1978) model of lithospheric flexing of the upper plate against the subducting, buoyant, aseismic ridge: in this case the subducting DEZ.

Westward compression and rotation of structural wedges across the central summit platform of the arc (Greene, Macfarlane, Johnson, and Crawford, 1988) continued throughout the Pliocene to Pleistocene, with compression occurring in the North Aoba Basin. East-west compression is shown by folding and thrusting along the western flank of Maewo Island on the Eastern Belt (Greene, Macfarlane, Johnson, and Crawford, 1988; Daniel et al., 1989; Pelletier et al., this volume). Along the Western Belt, uplift (Taylor et al., 1985, 1987) and dilatational stresses in drill holes in the DEZ-arc collision zone (Figs. 7 and 28) indicate east-west compression. Krammer and Chabernaud (this volume) state that borehole televiewer (BHTV) and formation microscanner (FMS) data show preferred elongation (east-northeast-westsouthwest) in the boreholes. These authors show a strong correlation with seafloor morphology and structural features in Hole 829A, formed by convergent compression ( $\mathrm{N} 33^{\circ} \mathrm{E}, \mathrm{DEZ}$ collision), and with the direction of plate convergence $\left(\mathrm{N} 58^{\circ} \mathrm{E}\right)$ in Hole $831 \mathrm{~B}$. Chabernaud (this volume) uses FMS data to show the imbricated structure of the thrust sheets in the accretionary complex. With compressional stress information inferred from breakout analyses and hydraulic fractures in holes of the North Aoba Basin, he shows east-northeast-west-southwest compression associated with latest Pliocene to Pleistocene uplift of the eastern flank of the basin. 


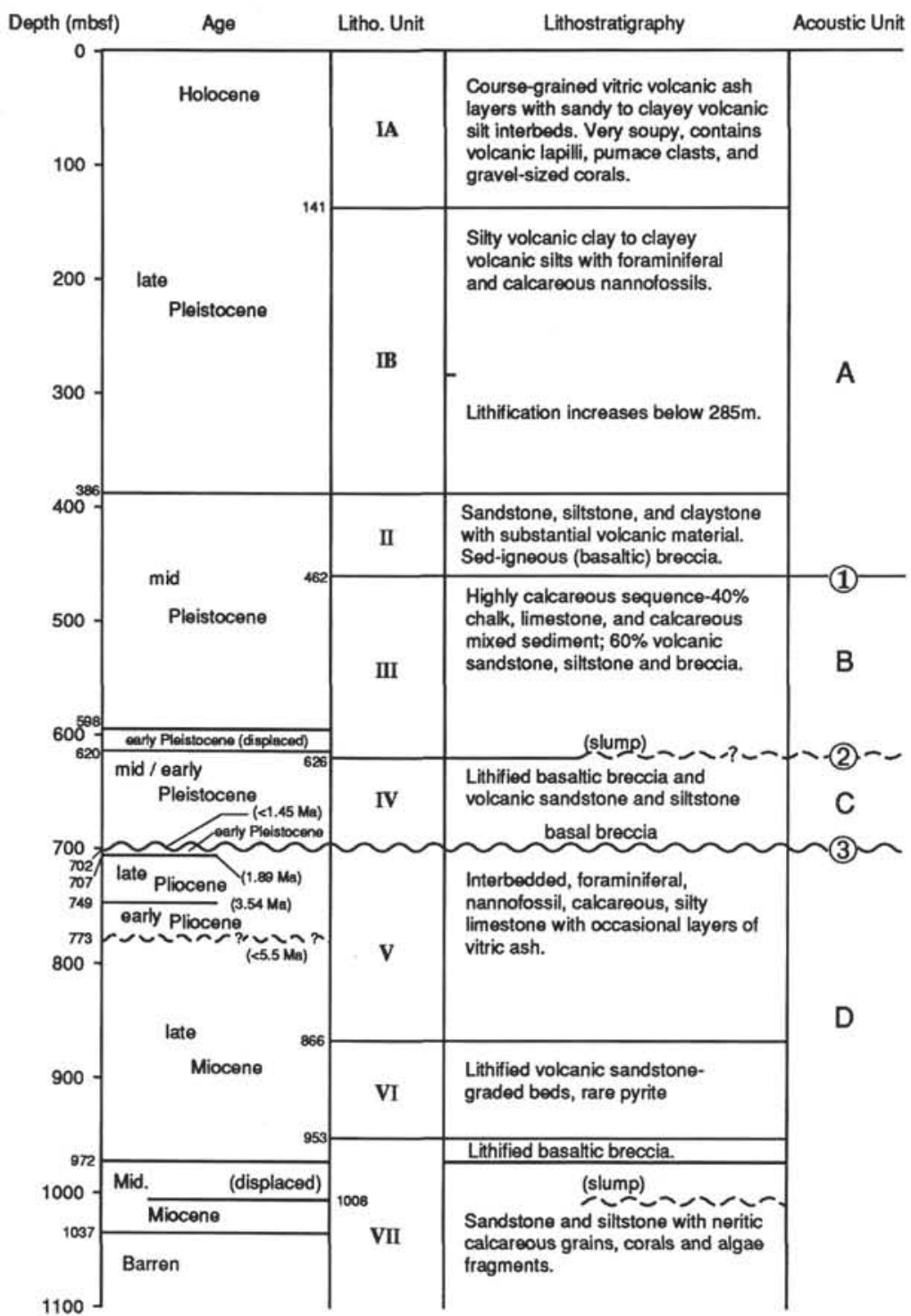

Figure 21. Lithologic column relating age and lithostratigraphy at Site 832 with seismic reflection acoustic units referred to in Figure 17. Circled numbers refer to unconformities identified in Figure 17 and wavy lines refer to unconformities found at Site 832, queried where questionable.

Volcanic activity from the late Pliocene onward was concentrated along the Central Chain. Isotopic data indicate that the DEZ collision had a profound effect on the composition of erupted magmas (Briqueu et al., this volume). Post-collision magmas carry an unusual "enriched" component indicating derivation from a very different isotopic reservoir than the pre-collision arc magmas, and lavas currently erupted away from the collision zone. Interestingly, the collision has had almost no effect on the major and trace element compositions of lavas (Hasenaka et al., this volume), with pre-collision sills and clasts having essentially identical range of compositions as the post-collision magmas.

Uplifted at the end of the Pliocene, extensive areas of both the Eastern and Western belts emerged to form shallow-water banks (Carney and Macfarlane, 1982; Fig. 29). In the Eastern Belt, carbonate rocks of the Raga Group continued to be deposited on Pentecost, accumulations of carbonate from reef growth occurred on Maewo (Fig. 5), and Vot Tande was emergent.

Basaltic sills drilled at Site 833B have striking compositional similarities, despite their greater age, to the high-Ti series lavas described by Eggins (1993) from Aoba volcano. They are probably associated with the transition from Eastern Belt magmatism to the generally higher-K Central Belt magmatism, and have provided key evidence for the pre-collision isotopic identity of arc magmatism in the central New Hebrides Island Arc (Briqueu et al., this volume).

Submergence began along the Western Belt near the Torres Island during the Pliocene to Pleistocene, with reef growth actively building a carbonate cap upon the older Tertiary volcanic and sedimentary rocks. During late Pliocene, the Tawoli Formation of Espiritu Santo Island was being deposited in mid-bathyal depths (1200-3000 m), Maewo Island was situated in lower mid-bathyal depths (1000-2000 m) (Fig. 27 ) and the depth of the North Aoba Basin during the Pliocene was probably between 3000 and $3500 \mathrm{~m}$ (Akimoto, this volume). The eastern part of Espiritu Santo, including the Cumberland Peninsula, was emerging as a horst block (Macfarlane et al., 1988). East of the island, the small half-graben basin (East Santo Basin; Fig. 19) was intercepting erosional sediment from the island, preventing a continuous flow of sediment to the North Aoba Basin. The Navaka Sands Formation and fringing carbonate reefs were forming in shallow waters on and around the southern part of the island, and most of Malakula Island lay in shallow water in which thick carbonate reefs were built up (Macfarlane et al., 1988). 


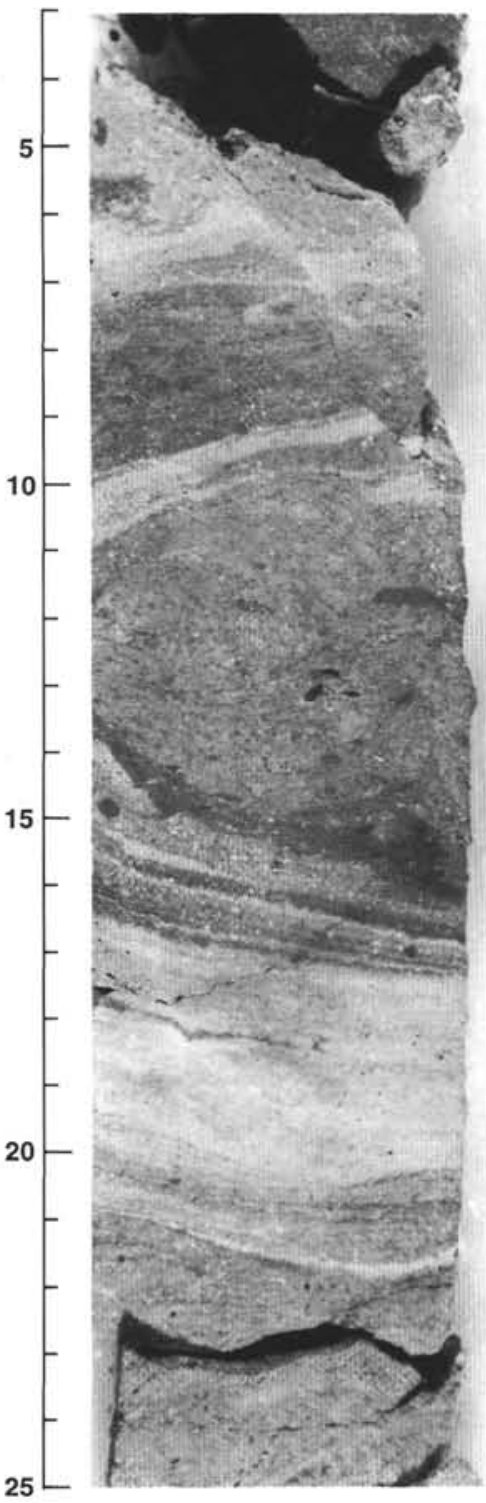

Figure 22. Photograph of a slump fold observed in Interval 134-832B-36R-2, $3-25 \mathrm{~cm}$. Fold occurs in upper Pliocene silty volcanic sandstone.

The full impact of the collision of the DEZ with the arc, at Espiritu Santo occurred from the late Pliocene onward. Buoyant upbowing from the subduction process, including the collision and subduction of the DEZ, localized tensional stress along the western part of the crest of the arc. This upbowing is reflected in the continued uplift along the arc-parallel normal faults (Fig. 4). Eventually the stress led to the present-day emergence of the Western and Eastern belts, slight downdropping of the Central Basins (North and South Aoba basins) in a synclinal fashion, and eastward tilting of the Western and Eastern belts (Greene, Macfarlane, Johnson, and Crawford, 1988; Pelletier et al., this volume; Goud Collins, this volume). The deepening Central Basins rapidly began in the Quaternary to accumulate volcanic ash from the active volcanic emissions of Ambrym, Aoba, and Santa Maria islands, as well as debris flows and turbidites originating from the steepening flanks of the Western and Eastern belt islands.

\section{Late Pleistocene to Holocene (Quaternary)}

The DEZ continued its northward migration during the Quaternary, with the North d'Entrecasteaux Ridge colliding with, and sub-

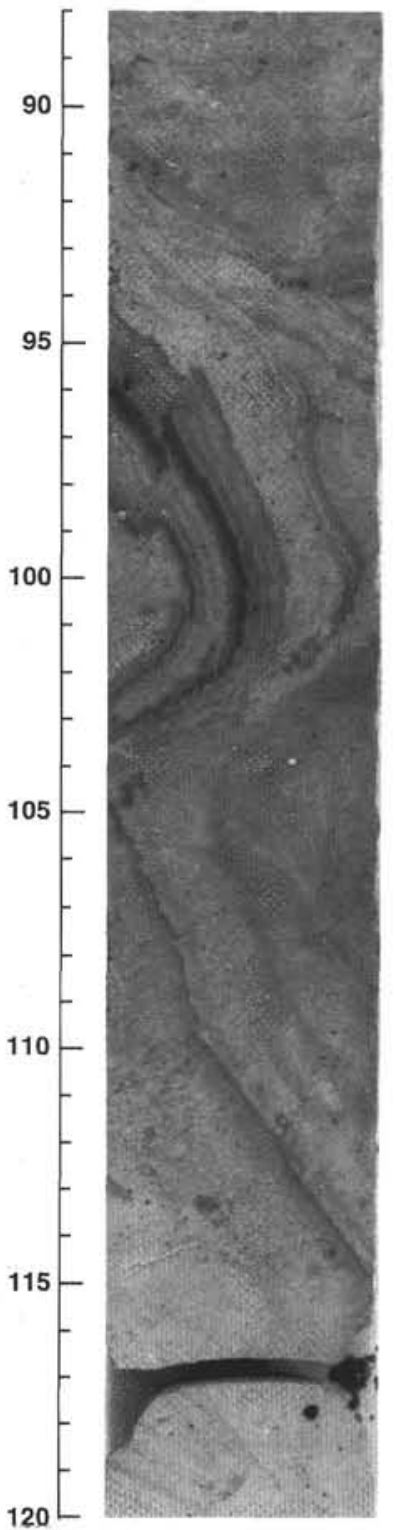

Figure 23. Photograph of Interval 134-833B-22R-2, 88-120 cm, showing faulted slump fold indicating slope instability along the eastern flank of the North Aoba Basin (NAB).

ducting beneath, Espiritu Santo Island (Fig. 26F). Offscraping of the sediment cover and surficial basement rocks of the North d'Entrecasteaux Ridge produced the small accretionary prism on the central forearc slope of the island and formed Wousi Bank. This northward migration has had a bow-wave effect on the seafloor and sediment of the forearc north of the North d'Entrecasteaux Ridge, as described by Collot and Fisher (1991). These authors also describe the effect as forearc uplift at the point of impact, where a compressional regime exists, and the effect as subsidence south of the North d'Entrecasteaux Ridge, where a tensional regime exists, in the wake of the passage of the ridge (Fig. 30). Taylor et al. (1985) state that Espiritu Santo and Malakula islands are physiographically equivalent to the Torres Islands further north, and that these islands are the expression of a former axis of an area that has a maximum uplift rate during this time. They also observed that the trace of subduction shifted westward because of the collision of the DEZ. The Bougainville Guyot of the South d'Entrecasteaux Chain started to be subducted (Fisher et al., 


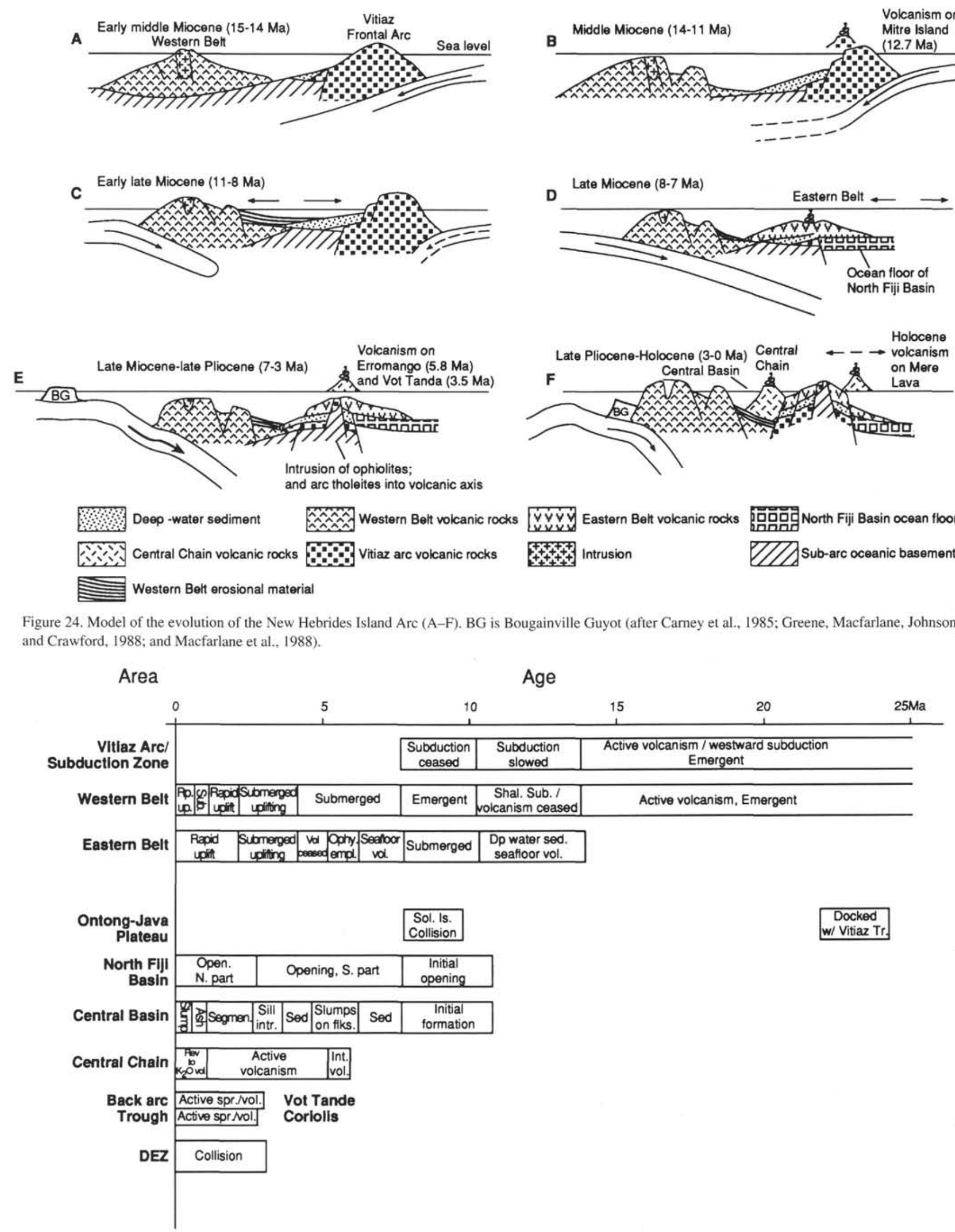

Figure 25. Chart showing timing ( age) of major tectonic events associated with the evolution of the New Hebrides Island Arc. Rp. is rapid, up. is uplift, sub. is submerged, shal. sub. is shallow subsidence, vol. is volcanism, Dp is deep, sed. is sedimentation, Sol. Is. is Solomon Islands, segmen. is segmentation, intr. is intrusion, flks. is flanks, Rev is reversion. Int. vol. is intrusive volcanics, active spr/vol. is active/spreading volcanism, Ophy. is ophiolite, empl. is emplaced. 

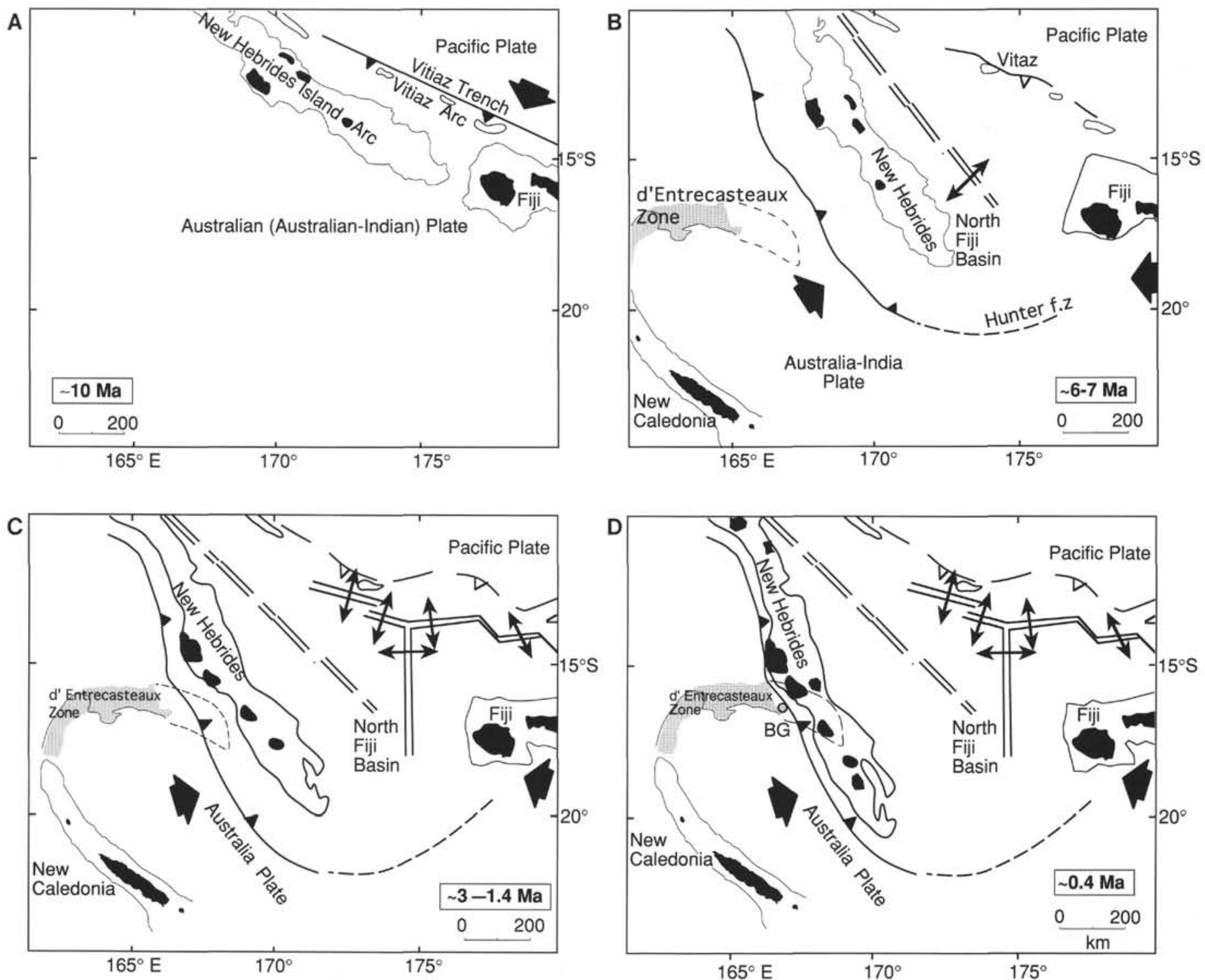

Figure 26. Neogene paleoconstruction of the New Hebrides Island Arc. A. 10 Ma when New Hebrides Island and Vitiaz arcs (outer Melanesian Arc of Packham and Falvey, 1971) were one arc. B. 6-7 Ma when initial splitting of the outer Melanesian Arc is estimated with a hinge point north and east of Erromango Island (Musgrave and Firth, 1993). C. 3-1.42 Ma when Western Belt of New Hebrides Island Arc is estimated to come in contact with the d'Entrecasteaux Zone (DEZ) based on relative spreading rates of Taylor et al. (this volume). Paleogeographic position of all physiographic features are drawn relative to a fixed Pacific Plate. BG is Bougainville Guyot (modified after Carney et al., 1985; Auzende et al., 1988; Macfarlane et al., 1988; and Greene, Macfarlane, Johnson, and Crawford, 1988). F.z. is fracture zone. D. 0.4 Ma, when North d'Entrecasteaux Ridge initiated collision with southern Espiritu Santo Island. E. Present-day tectonic setting of the New Hebrides Island Arc and North Fiji Basin.

1986; Fisher, 1986; Collot and Fisher, 1988) along the forearc slope south of Espiritu Santo Island at this time.

The forearc slope of the New Hebrides Island Arc is composed of offscraped North d'Entrecasteaux Ridge materials in discrete and finite thrust sheets. Speculation based on this and the varying deformation occurring today from the impact of the DEZ leads us to suggest that the thrust-staked forearc slope is representative of the evolving forearc since inception of collision. Therefore, we suspect that the forearc slope from offshore Epi Island to central Espiritu Santo Island is composed of lenses or "flakes" of accreted and distorted thrust sheets of Oligocene to lower Miocene chalks and Pliocene to Pleistocene volcanic siltstones (Figs. 9 and 30). According to seismic reflection data (Collot et al., this volume), these "flakes" would be on the order of 3-5 km wide and composed of imbricated thrust sheets of $300-500 \mathrm{~m}$ or so thick, which cover the forearc slope with shingled layers of thrust sheets. Deformation of these "flakes" would occur where seamounts of the South d'Entrecasteaux Chain impinge upon the forearc slope, docking or subduction of seamounts of the South d'Entrecasteaux Chain probably overprint or erode the offscraped materials from the North d'Entrecasteaux Ridge. In the area where the Bougainville Guyot is impacting the forearc slope, we speculate that previously deposited "flakes" are severely deformed and some are carried deep into the forearc with the leading edge of the guyot.

Taylor et al. (1985) proposed that underthrusting of the higher ocean floor of the DEZ accounts for a fairly high rate of uplift along the trend of the Western Belt (Espiritu and Malakula islands) and that the irregular topography of the DEZ influences both the pattern of the block-controlled uplift and segmentation of the arc in terms of concentration of seismicity. Tilts of once flat erosional surfaces of the central Western Belt islands are perpendicular to the arc trend of 


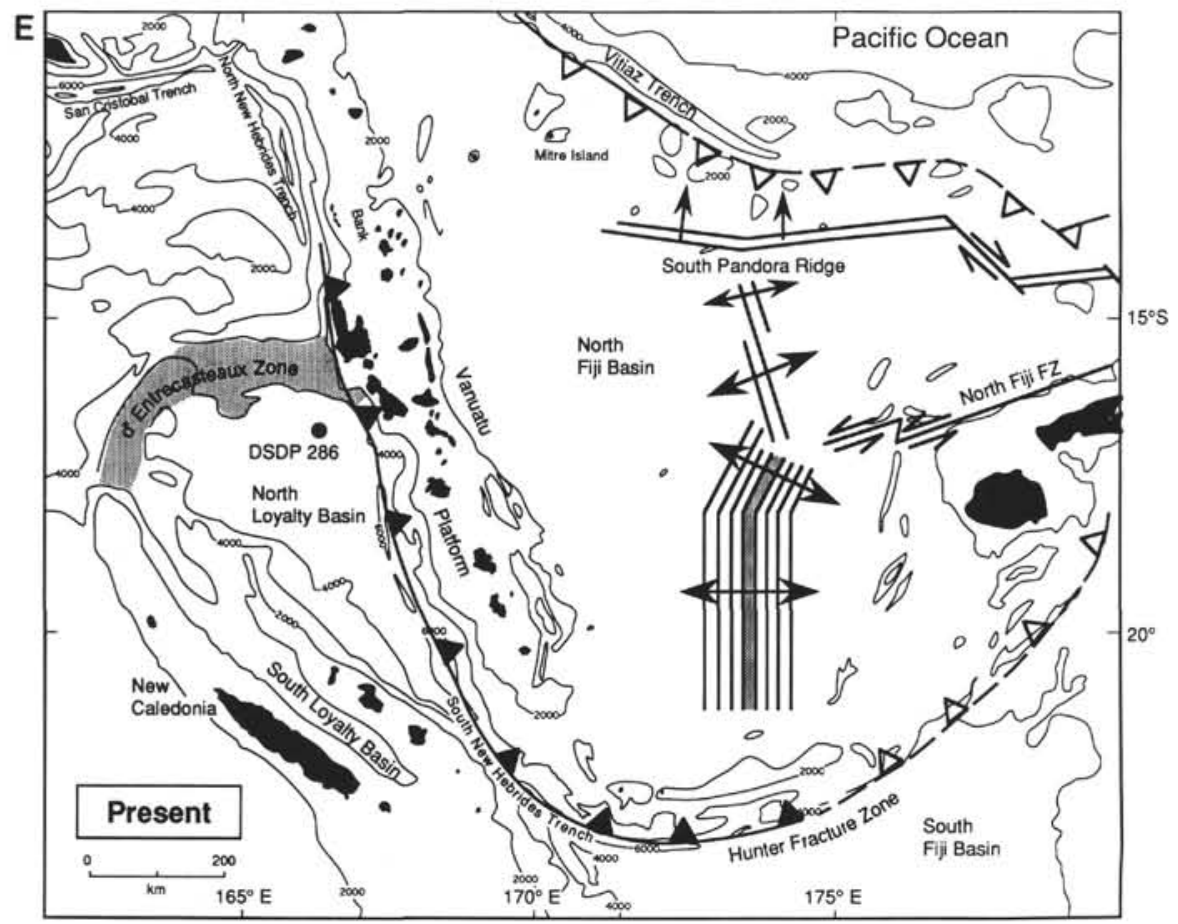

Figure 26 (continued).
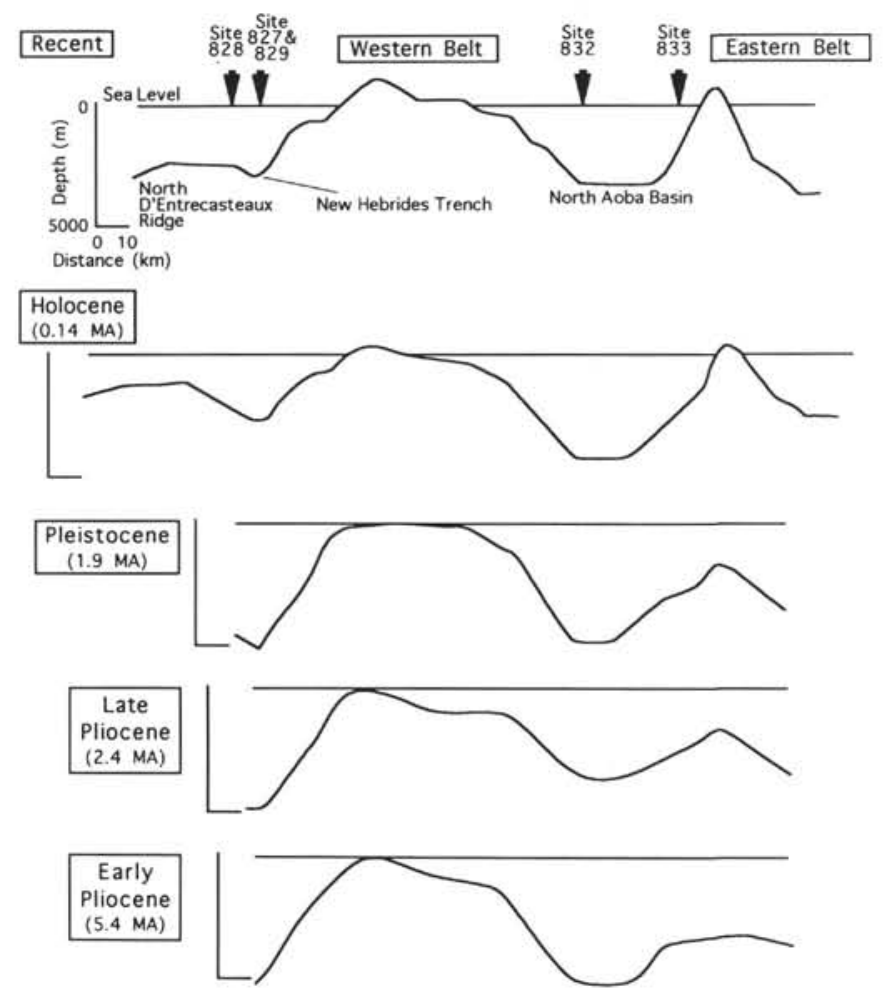

Figure 27. Schematic cross sections of the central New Hebrides Island Arc showing paleodepths and elevations from early Pliocene time (modified after Akimoto, this volume).

$\mathrm{N} 20^{\circ} \mathrm{W}$ and probably represent the influence of the DEZ collision along Espiritu Santo Island (Taylor et al., 1985).

The collision of the DEZ has modified the Central Basins area, including the North Aoba Basin, dramatically. The Ambrym and Aoba fracture zones have offset structural elements and allowed the intrusion of magma from depth (Fig. 4; Greene, Macfarlane, Johnson, and Craw-

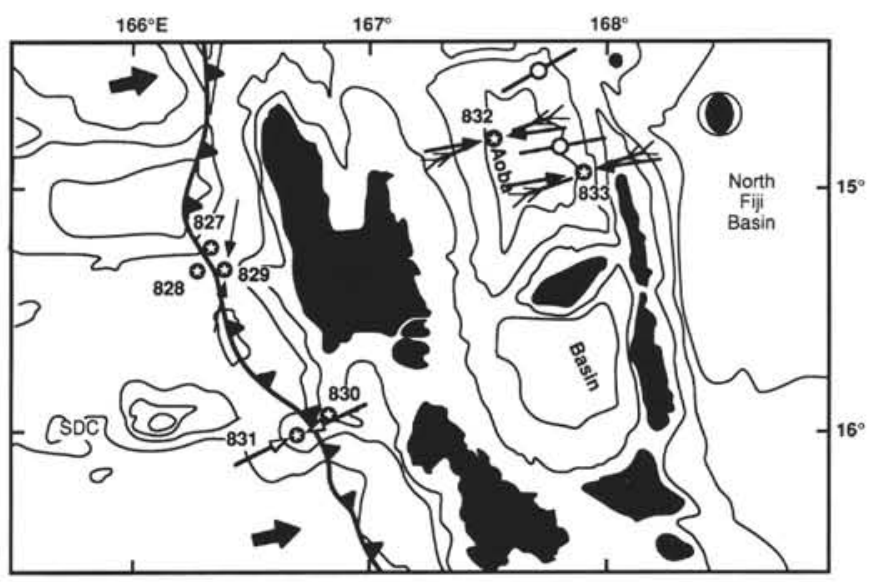

Figure 28. Breakouts and other structural stresses observed in drill holes and interpreted from seismicity data (Louat and Pelletier, 1989). These measurements indicate nearly orthogonal collision. Starred dots are drill sites; doubletailed lines indicate vertically induced fractures; thin lines with arrows give orientation of stress from breakouts (Chabernaud, this volume); open arrowed lines give orientation of stress from breakouts (Krammer et al., this volume); open circled lines give orientation of stress from seismic studies (Louat and Pelletier, 1989); beach ball indicates thrust motion from average focal mechanism solutions (Louat and Pelletier, 1989); barbed line indicates seafloor trace of subduction zone; filled large arrows indicate direction of plate motion; brick pattern is limestone; dotted pattern indicate areas of marine sedimentation (after Krammer et al., this volume.).

ford, 1988). The subdivision of the Central Basins appears to have started sometime after 1.0-1.8 Ma, when the islands of Ambrym and Aoba began to form as submarine edifices, based on the rate $(\sim 3-4 \mathrm{~cm} / \mathrm{yr})$ of DEZ northward migration defined by Taylor et al. (this volume).

During the Quaternary, when the Western and Eastern belts in the central part of the New Hebrides Island Arc were being uplifted, the Central Basins evolved from open-ocean to more restrictive enclosed conditions. Due primarily to tectonic activity, depths of the basins 


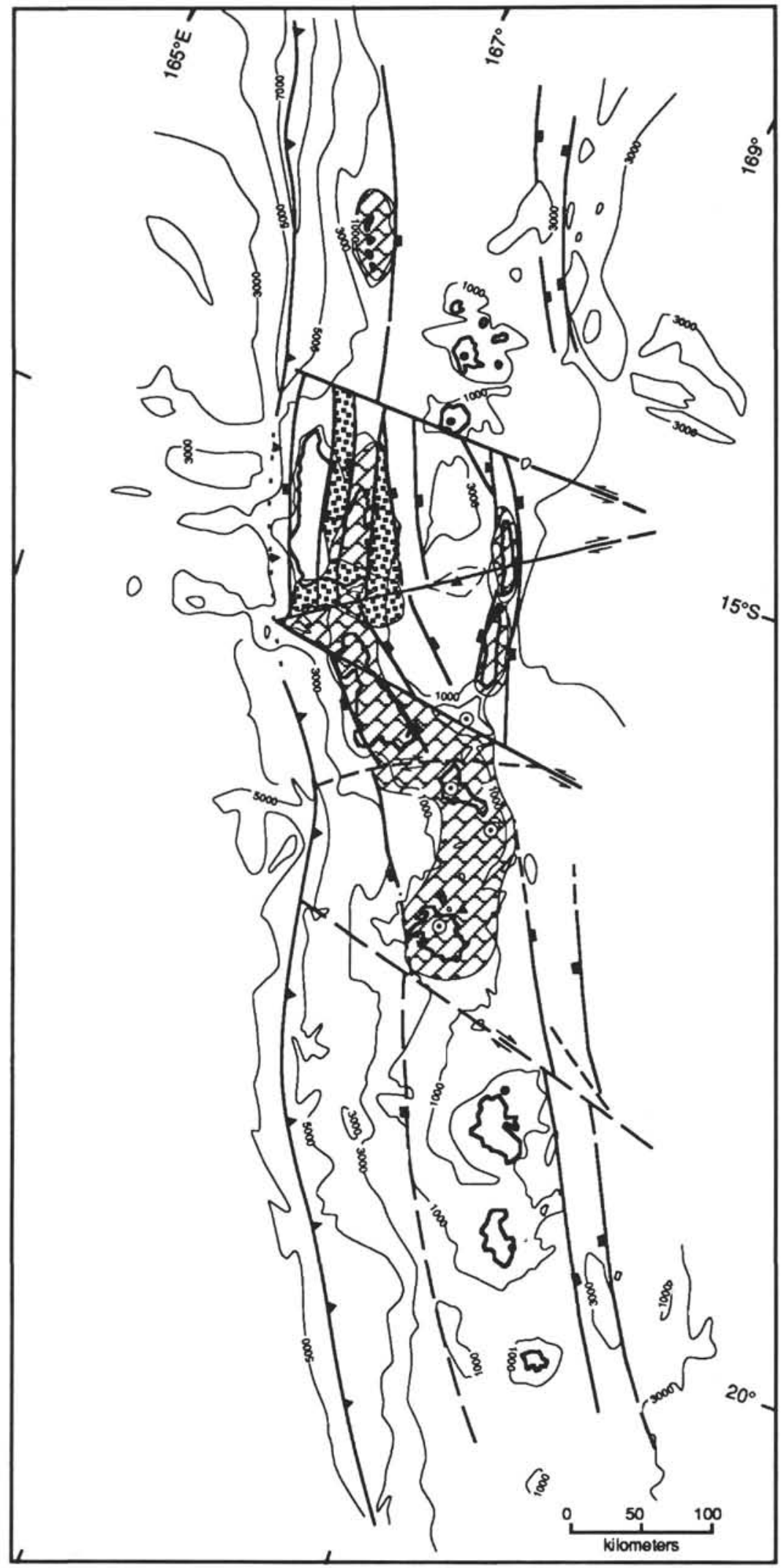

Figure 29. Map showing extensive area of shallow-water carbonate deposition during the phase of Pliocene to Pleistocene submergence. Bold and dashed (inferred) lines show location of faults and fracture zones, boxes on downdropped side, arrows indicate direction of motion; barbed line shows trace of subduction zone, dotted where no physiographic expression exists. Bathymetry in meters (modified after Greene, Macfarlane, Johnson, and Crawford, 1988). 


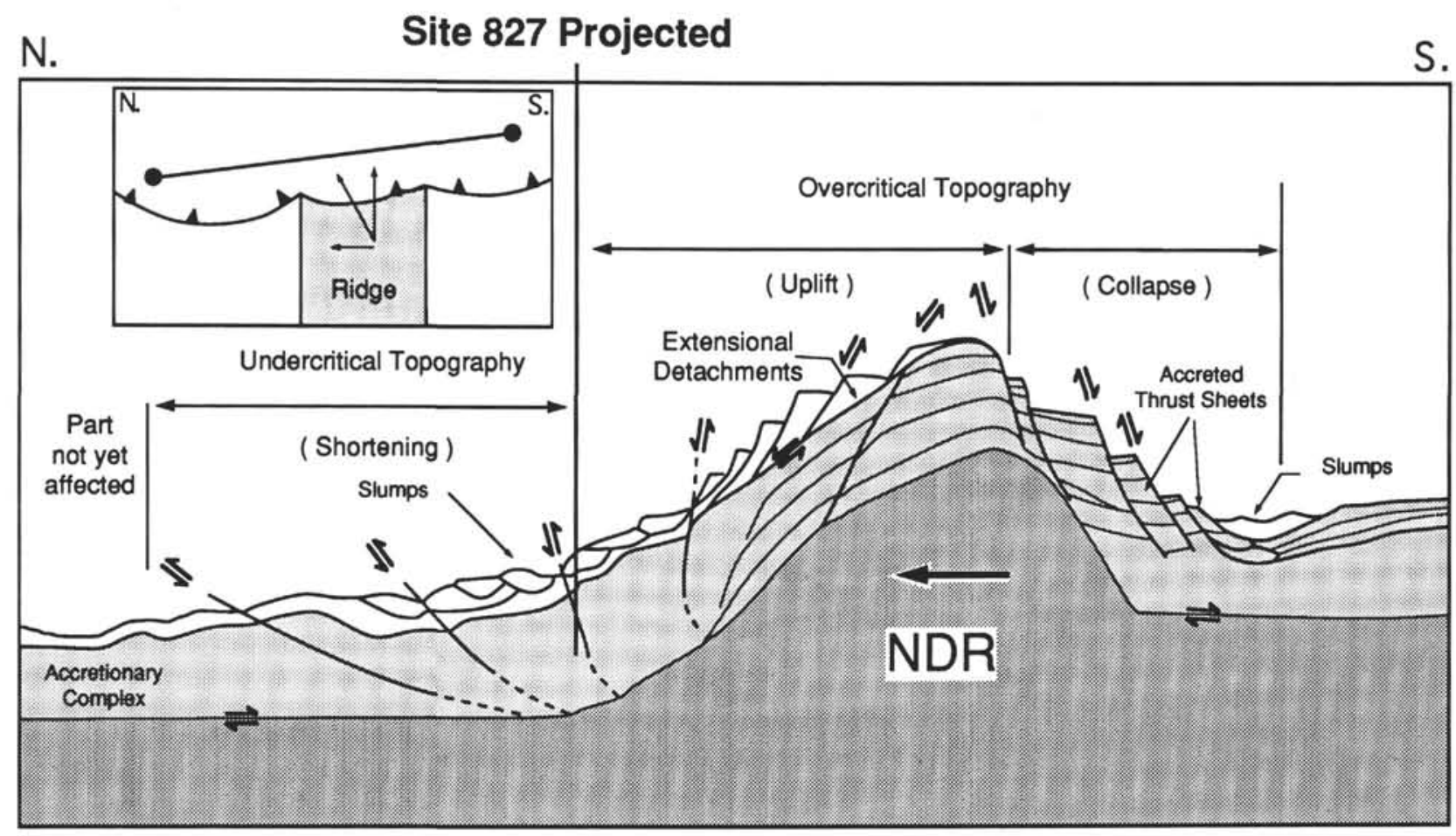

Figure 30. Conceptual model of North d'Entrecasteaux Ridge (NDR) obliquely subducting beneath the New Hebrides Island Arc and showing accumulation and distortion of NDR accreted material ("flakes") being deposited in the wake of the northward migration of the NDR (modified after Collot and Fisher, 1991).

fluctuated greatly. Akimoto (this volume), on the basis of analyses of large benthic foraminifers, shows that during the early Pleistocene the paleodepths of the North Aoba Basin subsided 500-1500 m, ultimately reaching abyssal depths of $4000-4500 \mathrm{~m}$ before shallowing. During late Pleistocene, the North Aoba Basin paleodepths changed from abyssal depths $(\sim 4000 \mathrm{~m})$ to the present depth of $3100 \mathrm{~m}$ (Akimoto, this volume).

Goud Collins (this volume) states that in the late Pleistocene sedimentation was dominated by volcanic ash flows as the Central Chain volcanoes built depositional aprons. Effusive ash falls also occurred, and this, along with hemipelagic deposition rapidly filled the North Aoba Basin to its present level.

\section{CONCLUSIONS}

Significant new data from this drilling contributes to the understanding of how arc-ridge collision deformation occurs and further constrains timing of DEZ collision, opening of North Fiji Basin, and relative convergence rates for the northeastern part of the Australian (Australia-India) Plate.

Westward transport of the arc occurred with the opening of the North Fiji Basin and the separation of the New Hebrides Island Arc from the Vitiaz Trench (Fig. 26). This counterclockwise transport of the New Hebrides Island Arc initiated sometime in the middle Miocene (10-12 Ma).

Normal forearc accretion and deformation probably occurred during the initial westward passage of the New Hebrides Island Arc, although this is not well documented and we were unable to detect early subduction deformation (deformation before the arrival of the DEZ) in our drill holes. Pleistocene as well as present-day offscraping of the North d'Entrecasteaux Ridge material onto the forearc slope of the central New Hebrides Island Arc is documented by the nine major and four minor thrust sheets penetrated during drilling at Site 829. Comparable lithologies found at Sites 828 and 829 document the offscraping.
Assuming that a substantial part (at least $250 \mathrm{~km}$ ) of the eastern DEZ has been subducted and that this subducted portion mimicked the present-day arcuate shape, we propose that the New Hebrides Island Arc first came into contact with the DEZ near the present location of Epi Island, sometime during the late Pliocene to early Pleistocene ( 1.5-3 Ma, using an average net convergence rate of 14-16 $\mathrm{cm} / \mathrm{yr}$ proposed by Taylor et al., this volume). Since that time, and because of the progressive clockwise rotation of the New Hebrides Island Arc and northwestward convergence of the Australian Plate, the arcuate DEZ has been migrating northward along a $250 \mathrm{~km}$ expanse of forearc slope at a rate of between 3.2 and $4.1 \mathrm{~cm} / \mathrm{yr}$ (Taylor et al., this volume), leaving accreted North d'Entrecasteaux Ridge material and deformed thrust sheets on the forearc slope (Fig. 30).

Because of the double-spined nature of the DEZ, at any given point on the arc where the collision occurs, the first offscraping of the North d'Entrecasteaux material and accretion to the forearc slope, is followed by subsidence and mass wasting of the forearc with the passage of the ridge. Further deformation occurs with the collision of the South d'Entrecasteaux Chain, which presently indents the forearc slope some $10 \mathrm{~km}$, creating severe mechanical stress that results in bedding plain thrust faults and forearc shortening.

The intra-arc North Aoba Basin is the product of multiple arc evolutionary processes consisting of downbowing in the central part and marginal uplift from subduction, fracturing and bifurcation of the original central basin. These processes formed the North and South Aoba basins, which are the direct product of subsidence between two uplifting island belts associated with the continued collision of the DEZ. Information obtained from the North Aoba Basin drill holes indicates that the proto-North Aoba Basin floor fluctuated in depth and received eroded terrigenous sediment and slump material from Espiritu Santo and Maewo islands (Pelletier et al., this volume; Goud Collins, this volume). The proto-North Aoba Basin underwent several episodes of hemipelagic, volcaniclastic, and effusive volcanic sedimentation in the Miocene time. One, possibly two, unconformities identified in the North Aoba Basin drill sites indicate tectonic events 
that changed the inclination of the North Aoba Basin flanks since Miocene time, initiating extensive mass wasting. A major unconformity at $\sim 700$ mbsf in Hole $832 \mathrm{~B}$ is a $0.13-0.44 \mathrm{~m}$.y. hiatus, which dates from 1.45 to 1.58 or $1.89 \mathrm{Ma}$ (Fig. 21) and results from an early Pleistocene DEZ collision with the arc at Espiritu Santo Island.

In addition, Leg 134 provided important geochemical data to show that the DEZ collision, which occurred more recently than $3.3 \mathrm{Ma}$ introduced to the magma source region of the post-collision magmas an isotopically "enriched" component. Crawford et al. (1988) indicated that the collision of the DEZ modified the distribution of arc volcanoes in that part of the arc affected by the collision. This component is increasingly evident in post-collisional magmas, despite showing no significant major and trace element differences from the pre-collision magmas. New data (Briqueu, this volume) indicate that the DEZ itself could not be the source of this enriched component, as drilled DEZ lavas are rather depleted in composition and show little difference from the southern New Hebrides Island Arc volcanoes. The identity and source of this component remain a puzzle.

Thick volcanic sandstone and ash sequences found at Site 833 represent rapid accumulation of Pleistocene volcaniclastic material from the active Central Chain volcanoes and erosional material from Espiritu Santo and Maewo. From early Pliocene to present, the paleobathymetry of the North Aoba Basin fluctuated (Akimoto, this volume). The North Aoba Basin gradually shallowed from below the CCD $(\sim 4500 \mathrm{~m})$ to the lower part of the lower bathyal $(3000-3500 \mathrm{~m})$.

Collision and subduction of the DEZ continues along with the offscraping of North d'Entrecasteaux Ridge material and formation of Wousi Bank, uplift of the Western Belt and Eastern Belt islands. fragmentation of the arc with arc transverse, transcurrent faulting, and active volcanism along the Central Chain. Accretion of the forearc is progressively moving to the north with the lateral migration of the North d'Entrecasteaux Ridge. Tectonic indentation and erosion are occurring where the Bougainville Guyot of the South d'Entrecasteaux Chain is colliding with the forearc slope. The forearc slope continues to be plated with the "flakes" of North d'Entrecasteaux Ridge accreted material. In the North Aoba Basin deposition of eroded and effusive volcanic material is proceeding to fill the basin at a rate of $286 \mathrm{~m} / \mathrm{m}$.y. (based on biostratigraphic analyses used to estimated sediment accumulation for the interval of 0-711 mbsf at Site 832; Collot, Greene, Stokking, et al., 1992).

At a mean relative convergence rate of $\sim 13 \mathrm{~cm} / \mathrm{yr}$, collision of the West Torres Massif off the north-central part of the New Hebrides Island Arc and the Loyalty Islands off the southern part of the arc is expected to occur in about 0.5 m.y. This future onset of collision and subduction will initiate new episodes of island building, intra-arc basin formation, arc fragmentation, and forearc accretion. Conceivably, the collision of the DEZ, West Torres Massif, and the Loyalty islands may prove too resistant to subduction, resulting in another episode of reversal in subduction polarity.

\section{ACKNOWLEDGMENTS}

We wish to thank all of our shipboard colleagues for their enthusiasm and hard work. Special thanks goes to Terry R. Bruns, Michael S. Marlow, Laura B. Stokking, and Robert J. Musgrave for their very thorough reviews and excellent suggested revisions; this manuscript benefited tremendously from their efforts. We also appreciate the dedication and assistance given to us by Susan Kalb of the U.S. Geological Survey in typing the manuscript and by Lynne McMasters and Diedra Sullivan of Moss Landing Marine Laboratories for drafting of figures and photographic work. The ODP staff, especially Gigi Delgado, were very helpful and patient in guiding us in the preparation of the manuscript and we appreciate this very much. This manuscript preparation was supported by U.S. Science Advisory Council Award \#8489.7795, administered through Moss Landing Marine Laboratories.

\section{REFERENCES}

American Association of Petroleum Geologists, 1985. Plate tectonic map of the Circum-Pacific region, southwest quadrant. Circum-Pacific Map Project (scale 1:10,000,000).

Ash, R.P., Carney, J.N., and Macfarlane, A., 1980. Geology of the northern Banks Islands. New Hebrides Geol. Surv. Reg. Rep., 52.

Auzende. J.-M., Lafoy, Y., and Marsset, B., 1988. Recent geodynamic evolution of the North Fiji Basin (Southwest Pacific). Geology, 16:925-929.

Bellon, H., Marcelot, G., Lefevre, C., and Maillet, P., 1984. Le volcan de l'île d'Erromango (République de Vanuatu): calendrier de l'activité (données $\left.{ }^{40} \mathrm{~K}-{ }^{40} \mathrm{Ar}\right)$. C. R. Acad. Sci. Ser. 2, 299:257-262.

Briqueu, L., and Lancelot, J.R., 1982. Sr isotopes and K, Rb, Sr balance in sediments and igneous rocks from the subducted plate of the Vanuatu New Hebrides active margin. Geochim. Cosmochim. Acta, 47:191-207.

Brocher, T.M., and Holmes, R., 1985. The marine geology of sedimentary basins south of Viti Levu, Fiji. In T.M. Brocher (Ed.), Geological Investigations of the Northern Melansian Borderland. Circum-Pac. Counc. Energy Miner. Resour., Earth Sci. Ser., 3:123-138.

Burne, R.V., Collot, J.-Y., and Daniel, J., 1988. Superficial structures and stress regimes of the downgoing plate associated with subduction-collision in the Central New Hebrides Arc (Vanuatu). In Greene, H.G., and Wong, F.L. (Eds.), Geology and Offshore Resources of Pacific Island Arcs-Vanuatu Region. Circum-Pac. Counc. Energy Miner. Resour., Earth Sci. Ser., 8:357-376.

Carney, J.N., and Macfarlane, A., 1977. Volcano-tectonic events and prePliocene crustal extension in the New Hebrides. Int. Symp. on Geody namics in South-west Pacific, Noumea, New Caledonia, 1976, 91-104.

1978. Lower to middle Miocene sediments on Maewo, New Hebrides, and their relevance to the development of the Outer Melanesian Arc system. Aust. Soc. Explor. Geophys. Bull., 9:123-130.

1979. Geology of Tanna, Aneityum, Futuna and Aniwa. New Hebrides Geol. Surv. Rep.

1980. A sedimentary basin in the central New Hebrides Arc. Tech Bull.-U.N. Econ. Soc. Comm. Asia Pac., Comm. Co-ord. Jt. Prospect Miner. Resour. South Pac. Offshore Areas, 3:109-120.

- 1982. Geological evidence bearing on the Miocene to Recent structural evolution of the New Hebrides Arc. Tectonophysics, 87:147175.

Carney, J.N., Macfarlane, A., and Mallick. D.I.J., 1985. The Vanuatu island arc: an outline of the stratigraphy, structure, and petrology. In Nairn, A.E.M., Stehli, F.G., and Uyeda, S. (Eds.), The Ocean Basins and Margins (Vol. 7): New York (Plenum), 685-718.

Charvis, P., and Pelletier, B., 1989. The northern New Hebrides back-arc troughs: history and relation with the North Fiji basin. Tectonophysics, 170:259-277.

Chase, C.G., 1971. Tectonic history of the Fiji plateau. Geol. Soc. Am. Bull. 82:3087-3110.

Chung, W.Y., and Kanamori, H., 1978. A mechanical model for plate deformation associated with aseismic ridge subduction in the New Hebrides arc. Tectonophysics, 50:29-40.

Coleman, P.J., and Packham, G.H., 1976. The Melanesian borderlands and India-Pacific plate boundaries. Earth-Sci. Rev., 12:197-233.

Colley, H., and Ash, R.P., 1971. The geology of Erromango. Reg. Rep.-New Hebrides Geol. Surv.

Collot, J.-Y., Daniel, J., and Burne, R.V., 1985. Recent tectonics associated with the subduction/collision of the d'Entrecasteaux zone in the central New Hebrides. Tectonophysics, 112:325-356.

Collot, J.-Y., and Fisher, M.A., 1988. Crustal structure from gravity data of a collision zone in the central New Hebrides Island Arc. In Greene, H.G., and Wong, F.L. (Eds.), Geology and Offshore Resources of Pacific Island Arcs-Vanuatu Region. Circum-Pac. Counc. Energy Miner. Resour., Earth Sci. Ser., 8:125-140.

1991. The collision zone between the North d'Entrecasteaux Ridge and the New Hebrides island arc. Part I: Sea Beam morphology and shallow structure. J. Geophys. Res., 96:4457-4478.

Collot, J.-Y., Greene, H.G., Stokking, L.B., et al., 1992. Proc. ODP, Init. Repts., 134: College Station, TX (Ocean Drilling Program).

"Abbreviations for names of organizations and publications in ODP reference lists follow the style given in Chemical Abstracts Service Source Index (published by American Chemical Society). 
Collot, J.-Y., Lallemand, S., Pelletier, B., Eissen, J.-P., Glaçon, G., Fisher, M.A., Greene, H.G., Boulin, J., Daniel, J., and Monzier, M., 1992. Geology of the d'Entrecasteaux-New Hebrides Arc collision zone: results from a deep submersible survey. Tectonophysics, 212:213-241.

Collot, J.-Y., Pelletier, B., Boulin, J., Daniel, J., Eissen, J.P., Fisher, M.A., Greene, H.G., Lallemand, S., and Monzier, M., 1989. Premiers résultats des plongees de la campagnee SUBPSOI dans la zone de collision des rides d'Entrecasteaux et de l'arc des Nouvelles Hébrides. C. R. Acad. Sci. Ser. 2, 309:1947-1954.

Crawford, A.J., Greene, H.G., and Exon, N.J., 1988. Geology, petrology and geochemistry of submarine volcanoes around Epi Island, New Hebrides Island Arc. In Greene, H.G., and Wong, F.L. (Eds.), Geology and Offshore Resources of Pacific Island Arcs-Vanuatu Region. Circum-Pac. Counc. Energy Miner. Resour., Earth Sci. Ser., 8:301-327.

Daniel, J., 1978. Morphology and structure of the southern part of the New Hebrides island arc system. J. Phys. Earth, 26:S181-S190.

Daniel, J., Gérard, M., Mauffret, A., Boulanger, D., Cautin, B., Collot, J.-Y., Durand, J., Fisher, M., Greene, H.G., Michaux, P., Pelletier, B., Pezzimenti, A., Renard, V., Schaming, M., and Tissot, J.D., 1989. Déformation compressive d'un bassin intra-arc dans un contexte de collision ride/arc: le bassin d'Aoba, arc des Nouvelles-Hébrides. C. R. Acad. Sci. Ser. 2. 308:239-245

Daniel, J., Jouannic, C., Larue, B., and Récy, J., 1977. Interpretation of d'Entrecasteaux zone (north of New Caledonia). Int. Symp. on Geody. namics in South-west Pacific. Noumea, New Caledonia, 1976. Paris (Editions Technip), 117-124.

Daniel, J., and Katz, H.R., 1981. D'Entrecasteaux zone, trench and western chain of the central New Hebrides island arc: their significance and tectonic relationship. Geo-Mar. Lett., 1:213-219.

Demets, C., Gordon, R.G., Argus, D.F., and Stein, S., 1990. Current plate motions. Geophys. J. Int., 101:425-478.

Dickinson, W.R., 1973. Widths of modern arc-trench gaps proportional to past duration of igneous activity in associated magmatic arcs. J. Geophys. Res. 78:3376-3389.

Dubois, J., Dugas, F., Lapouille, A., and Louat, R., 1975. Fossés d'effondrement en arrière de l'arc des Nouvelles-Hébrides-mécanismes proposés. Rev. Geogr. Phys. Geol. Dyn., 17:73-94.

1978. The troughs at the rear of the New Hebrides island arc - possible mechanisms of formation. Can. J. Earth Sci., 15:351-360.

Dubois, J., Launay, J., and Recy, J., 1974. Uplift movements in New Caledonia-Loyalty Islands area and their plate tectonics interpretation. Tectonophysics, 24:133-150.

Dugas, F., Dubois, J., Lapouille, A., Louat, R., and Ravenne, C., 1977. Structural characteristics and tectonics of an active island arc: The New Hebrides. Int. Symp. on Geodynamics in South-west Pacific. Noumea, New Caledonia, 1976. Paris (Editions Technip), 79-90.

Eggins, S.M., 1993. Origin and differentiation of picritic arc magmas, Ambac and Aoba, Vanuatu. Contrib. Mineral. Petrol., 114:79-100.

Falvey, D.A., 1975. Arc reversals, and a tectonic model for the North Fiji Basin. Australas. Soc. Explor. Geophys. Bull., 6:47-49.

1978. Analysis of paleomagnetic data from the New Hebrides. Australas. Soc. Explor: Geophys. Bull., 9:117-123.

Falvey, D.A., and Greene, H.G., 1988. Origin and evolution of the sedimentary basins of the New Hebrides Arc. In Greene, H.G., and Wong, F.L. (Eds.) Geology and Offshore Resources of Pacific Island Arcs-Vanuatu Region. Circum-Pac. Counc. Energy Miner. Resour., Earth Sci. Ser., 8:413-442.

Fisher, M.A., 1986. Tectonic processes at the collision of the d'Entrecasteaux zone and the New Hebrides island arc. J. Geophys. Res., 91:10470-10486.

Fisher, M.A., Collot, J.-Y., and Geist, E.L., 1991. The collision zone between the North d'Entrecasteaux Ridge and the New Hebrides Island Arc. Part 2: structure from multichannel seismic data. J. Geophys. Res., 96:44794495.

Fisher, M.A., Collot, J.-Y., and Smith, G.L., 1986. Possible causes for structural variation where the New Hebrides island arc and the d'Entrecasteaux zone collide. Geology, 14:951-954.

Fisher, M.A., Falvey, D.A., and Smith, G.L., 1988. Seismic stratigraphy of the summit basins of the New Hebrides island arc. In Greene, H.G., and Wong, F.L. (Eds.). Geology and Offshore Resources of Pacific Island ArcsVanuatu Region. Circum-Pac. Counc. Energy Miner. Resour., Earth Sci. Ser., 8:201-223.

Gill, J.B., and Gorton, M.P., 1973. A proposed geological and geochemical history of eastern Melanesia. In Coleman, P.J. (Ed.), The Western Pacific: Island Arcs, Marginal Seas and Geochemistry: Perth (Univ. of Western Australia Press), 543-566.
Gorton, M.P., 1974. The geochemistry and geochronology of the New Hebrides [Ph.D. dissert.]. Australian National Univ., Canberra.

Greenbaum, D., Mallick, D.I.J., and Radford, N.W., 1975. Geology of the Torres Islands. Reg. Rep.- New Hebrides Geol. Surv.

Greene, H.G., Collot, J.-Y., Pelletier, B., and Lallemand, S., 1992. Observation of forearc seafloor deformation along the north d'Entrecasteaux RidgeNew Hebrides Island Arc collision zone from Nautile submersible. In Collot, J.-Y., Greene, H.G., Stokking, L.B., et al., Proc. ODP, Init. Repts., 134: College Station, TX (Ocean Drilling Program), 43-53.

Greene, H.G., and Johnson, D.P., 1988. Geology of the central basin region of the New Hebrides arc inferred from single-channel seismic-refraction data. In Greene, H.G., and Wong, F.L. (Eds.), Geology and Offshore Resources of Pacific Island Arcs-Vanuatu Region. Circum-Pac. Counc. Energy Miner. Resour., Earth Sci. Ser., 8:117-199.

Greene, H.G., Johnson, D.P., Macfarlane, A., and Wong, F.L., 1988. Geologic map of the central basin region, Vanuatu, Southern Pacific. In Greene, H.G. and Wong, F.L. (Eds.), Geology and Offshore Resources of Pacific Island Arcs-Vanuatu Region. Circum-Pac. Counc. Energy Miner. Resour., Earth Sci. Ser., 8: plate 1.

Greene, H.G., Macfarlane, A., Johnson, D.A., and Crawford, A.J., 1988. Structure and tectonics of the central New Hebrides Arc. In Greene, H.G., and Wong, F.L. (Eds.), Geology and Offshore Resources of Pacific Island Arcs-Vanuatu Region. Circum-Pac. Counc. Energy Miner. Resour., Earth Sci. Ser., 8:377-412.

Greene, H.G., Macfarlane, A., and Wong, F.L., 1988. Geology and offshore resources of Vanuatu-introduction and summary. In Greene, H.G., and Wong, F.L. (Eds.), Geology and Offshore Resources of Pacific Island Arcs-Vanuatu Region. Circum-Pac. Counc. Energy Miner. Resour., Earth Sci. Ser., 8:1-25.

Hanus, V., and Vanek, J., 1983. Deep structure of the Vanuatu (New Hebrides) islands arc: intermediate depth collision of subducted lithospheric plates. N.Z. J. Geol. Geophys., 26:133-154.

Holmes, M.L., 1988. Seismic refraction measurements in the summit basins of the New Hebrides Arc. In Greene, H.G., and Wong, F.L. (Eds.), Geology and Offshore Resources of Pacific Island Arcs-Vanuatu Region. CircumPac. Counc. Energy Miner. Resour., Earth Sci. Ser., 8:163-176.

Hughes, G.W., 1978. The relationship between volcanic island genesis and the Indo-Australian Pacific margin in the Eastern Outer Islands, Solomon Islands, south-west Pacific. J. Phys. Earth, 26 (suppl.):S123-S139.

Johnson, D.P., and Greene, H.G., 1988. Modern depositional regimes, offshore Vanuatu. In Greene, H.G., and Wong. F.L. (Eds.), Geology and Offshore Resources of Pacific Island Arcs-Vanuatu Region. Circum-Pac. Counc. Energy Miner. Resour., Earth Sci. Ser., 8:287-300.

Karig, D.E., and Mammerickx, J., 1972. Tectonic framework of the New Hebrides island arc. Mar: Geol., 12:187-205.

Katz, H.R., 1981. Report on interpretation of seismic profiling data collected on the Vauban cruise in Vanuatu waters. Tech. Bull.-U. N. Econ. Soc. Comm. Asia Pac., Comm. Co-ord Jt. Prospect Miner. Resour. South Pac. Offshore Areas, 12.

1988. Offshore geology of Vanuatu-previous work. In Greene, H.G., and Wong, F.L. (Eds.), Geology and Offshore Resources of Pacific Island Arcs-Vanuatu Region. Circum-Pac. Counc. Energy Miner. Resour., Earth Sci. Ser., 8:93-122.

Kroenke, L.W., 1984. Introduction. In Kroenke, L.W. (Ed.), Cenozoic Tectonic Development of the Southwest Pacific. Tech. Bull.-U. N. Econ. Soc. Comm. Asia Pac., Comm. Co-ord. Jt. Prospect Miner. Resour. South Pac. Offshore Areas, 6:1-11.

Kroenke, L.W., Jouannic, C., and Woodward, P. (Compilers), 1983. Bathymetry of the southwest Pacific. Chart 1: Geophysical Atlas of the Southwest Pacific (scale 1:6,442,192 at $0^{\circ}$, Suva, Fiji). U.N. Econ. Soc. Comm. Asia Pac., CCOP/SOPAC Tech. Sec.

Louat, R., Hamburger, M., and Monzier, M., 1988. Shallow and intermediatedepth seismicity in the New Hebrides Arc: constraints on the subduction process. In Greene, H.G., and Wong, F.L. (Eds.), Geology and Offshore Resources of Pacific Isiand Arcs-Vanuatu Region. Circum-Pac. Counc. Energy Miner. Resour., Earth Sci. Ser., 8:329-356.

Louat, R., and Pelletier, B., 1989. Seismotectonics and present-day relative plate motions in the New Hebrides-North Fiji basin region. Tectonophysics, 167:41-55.

Luyendyk, B.P., Bryan, W.B., and Jezek, P.A., 1974. Shallow structure of the New Hebrides island arc. Geol. Soc. Am. Bull., 85:1287-1300.

Macfarlane, A., Carney, J.N., Crawford, A.J., and Greene, H.G., 1988. Vanuatu-a review of the onshore geology. In Greene, H.G., and Wong, F.L. (Eds.), Geology and Offshore Resources of Pacific Island Arcs-Vanuatu 
Region. Circum-Pac. Counc. Energy Miner. Resour., Earth Sci. Ser., 8:45-91.

Maillet, P., Monzier, M., Selo, M., and Storzer, D., 1983. The d'Entrecasteaux zone (southwest Pacific): a petrological and geochronological reappraisal. Mar: Geol.. 53:179-197.

Malahoff, A., 1970. Gravity and magnetic studies of the New Hebrides island arc. Spec. Rep.-New Hebrides Geol. Surv.

Malahoff, A., Feden, R.H., and Fleming, H.S., 1982. Magnetic anomalies and tectonic fabric of marginal basins north of New Zealand. J. Geophys. Res., 87:4109-4125.

Mallick, D.I.J., 1973. Some petrological and structural variations in the New Hebrides. In Coleman, P.J. (Ed.), The Western Pacific: Island Arcs, Marginal Seas, Geochemistry: New York (Crane, Russak and Co.), 193-211. , 1975. Development of the New Hebrides Archipelago. Philos. Trans. R. Soc. London B, 277:277-285.

Mallick, D.I.J., and Greenbaum, D., 1977. Geology of Southern Santo. Reg. Rep.-New Hebrides Geol. Surv., 3.

Mallick, D.I.J., and Neef, G., 1974. Geology of Pentecost. Reg. Rep.-New Hebrides Geol. Surv.

Marthelot, J.-M., Chatelain, J.L., Isacks, B.L., Cardwell, R.K., and Coudert, E., 1985. Seismicity and attenuation in the central Vanuatu (New Hebrides) islands: a new interpretation of the effect of subduction of the d'Entrecasteaux fracture zone. J. Geophys. Res., 90:8641-8650.

Minster, J.B., and Jordan, T.H., 1978. Present-day plate motions. J. Geophys. Res., 83:5331-5354.

Mitchell, A.H.G., 1966. Geology of South Malekula. Rep.-New Hebrides Geol. Surv., 3. Surv.

Mitchell, A.H.G., and Warden, A.J., 1971. Geological evolution of the New Hebrides island arc. J. Geol. Soc. London, 127:501-529.

Monzier, M., Collot, J.-Y., and Daniel, J., 1983. Carte bathmétrique des parties centrale et méridonale de l'arc insulaire des Nouvelles-Hébrides. Paris (ORSTOM) (scale: approx. 131,000).

Musgrave, R.J., and Firth, J.V., 1993. Magnitude and timing of New Hebrides Arc rotation following spreading propagation in the North Fiji Basin: paleomagnetic evidence from Nendo, Solomon Island. In Wheller, G.E. (Ed.), Islands and Basins: Correlation and Comparison of Onshore and Offshore Geology. Abstracts, Sci. Tect. and Res. (STAR), 22nd SOPAC Session, So. Pac. Appl. Geosci. Commis. (SOPAC) Misc. Rep., 159:9-10.

Packham, G.H., and Falvey, D.A., 1971. An hypothesis for the formation of marginal seas in the western Pacific. Tectonophysics, 11:79-109.

Pascal, G., Isacks, B.L., Barazangi, M., and Dubois, J., 1978. Precise relocations of earthquakes, and seismotectonics of the New Hebrides island arc. J. Geophys. Res., 83:4957-4973.

Pigram, C.J., Davies, P.J., Feary, D.A., and Symonds, P.A., 1992. Absolute magnitude of the second-order middle to late Miocene sea-level fall. Marion Plateau, northeast Australia. Geology, 20:858-862.
Price, R.C., Maillet, P., and Johnson, D.P., 1993. Interpretation of GLORIA side-scan sonar imagery for the Coriolis Troughs of the New Hebrides backarc. Geo-Mar: Lett., 13:71-81.

Ravenne, C., Pascal, G., Dubois, J., Dugas, F., and Montadert, L., 1977. Model of a young intra-oceanic arc: the New Hebrides island arc. In Int. Symp. on Geodynamics in South-west Pacific, Noumea, New Caledonia, 1976: Paris (Editions Technip), 63-78.

Recy, J., Charvis, P., Ruellan, E., Monjaret, M.C., Gerard, M., Auclair, G., Baldassari, C., Boirat, J.M., Brown, G.R., Butscher, J., Collot, J.-Y.. Daniel, J., Louat, R., Monzier, M., and Pontise, B., 1986. Tectonique et volcanisme sous-marin a l'arrière de l'arc des Nouvelles-Hébrides (Vanuatu, Pacifique sud-ouest): résultats préliminaries de la compagne SEAPSO Leg II du N/O Jean Charcot. C. R. Acad. Sci. Ser. 2, 303:685-690.

Recy, J., Pelletier, B., Charvis, P., Gerard, M., Monjaret, M.-C., and Maillet, P., 1990. Structure, age, et origine de fossés arrière-arc de NouvellesHebrides (Sud-Ouest Pacifique). Oceanol. Acta, spec. vol., 10:165-182.

Shipboard Scientific Party, 1975. Site 286. In Andrews, J.E., Packham, G., et al., Init. Repts. DSDP, 30: Washington (U.S. Govt. Printing Office), 69-131.

Taylor, F.W., Frohlich, C., Lecolle, J., and Strecker, M.R., 1987. Analysis of partially emerged corals and reef terraces in the central Vanuatu Arc: comparison of contemporary coseismic and nonseismic with Quaternary vertical movements. J. Geophys. Res., 92:4905-4933.

Taylor, F.W., Isacks, B.L., Jouannic, C., Bloom, A.L., and Dubois, J., 1980. Coseismic and Quaternary vertical tectonic movements, Santo and Malekula Islands, New Hebrides island arc. J. Geophys. Res., 85:53675381.

Taylor, F.W., Jouannic, C., and Bloom, A.L., 1985. Quaternary uplift of the Torres Islands, northern New Hebrides frontal are: comparison with Santo and Malekula Islands, central New Hebrides frontal arc. J. Geol., 93:419438.

Tiffin, D.L., Clarke, J.E.H., Jarvis, P.J., Hill, P., Huggett, Q., Parson, L., Price, R.C., and Shipboard Party, 1990. CCOP/SOPAC GLORIA survey, Port Vila-Apia-Port Vila on HMAS Cook. SOPAC Cruise Rep., 130.

Weissel, J.K., Watts, A.B., and Lapouille, A., 1982. Evidence for late Paleocene to late Eocene sea floor in the southern New Hebrides Basin. Tectonophysics, 87:243-251.

Wong, F.L., and Greene, H.G., 1988. Geologic hazards identified in the Central Basin region, Vanuatu. In Greene, H.G., and Wong, F.L. (Eds.), Geology and Offshore Resources of Pacific Island Arcs - Vanuatu Region. CircumPac. Counc. Energy Miner. Resour., Earth Sci. Ser., 8:225-254.

\footnotetext{
Date of initial receipt: 31 May 1993

Date of acceptance: 5 November 1993

Ms 134SR-002
} 